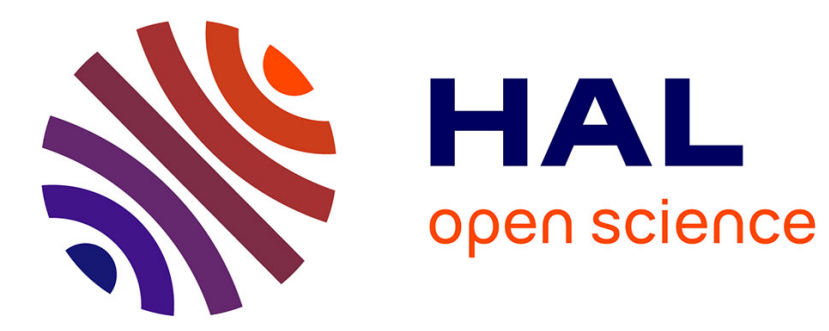

\title{
The French Unhappiness Puzzle: the Cultural Dimension of Happiness
}

Claudia Senik

\section{To cite this version:}

Claudia Senik. The French Unhappiness Puzzle: the Cultural Dimension of Happiness. 2014. halshs$00628837 \mathrm{v} 6$

\author{
HAL Id: halshs-00628837 \\ https://shs.hal.science/halshs-00628837v6
}

Preprint submitted on 12 Sep 2014

HAL is a multi-disciplinary open access archive for the deposit and dissemination of scientific research documents, whether they are published or not. The documents may come from teaching and research institutions in France or abroad, or from public or private research centers.
L'archive ouverte pluridisciplinaire HAL, est destinée au dépôt et à la diffusion de documents scientifiques de niveau recherche, publiés ou non, émanant des établissements d'enseignement et de recherche français ou étrangers, des laboratoires publics ou privés. 


\section{PARISSCHOOL OF ECONOMICS}

WORKING PAPER N ${ }^{\circ}$ 2011-34

The French Unhappiness Puzzle: the Cultural Dimension of Happiness

Claudia Senik

JEL Codes: I31, H52, J61, 015, 052, Z10

Keywords: Happiness, Unhappiness, Subjective Well-Being, International Comparisons, France, Immigration, European Social Survey

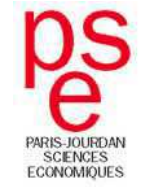




\section{The French Unhappiness Puzzle: the Cultural Dimension of Happiness}

First version November 2011

This version May 2014

Claudia Senik

Université Paris-Sorbonne and Paris School of Economics

PSE, 48 bd Jourdan

75014 Paris

France

e-mail: senik@pse.ens.fr

Telephone. + 33616557515

Fax: + 33143136310

http://www.parisschoolofeconomics.eu/fr/senik-claudia/ 


\section{Highlights}

International differences in happiness are large but essentially unexplained.

The French idiosyncratic unhappiness is one of these puzzles. It concerns self-declared happiness as well as short-run emotional wellbeing.

Cultural and mental attitudes play a large role in explaining these happiness gaps.

Indeed, immigrants and natives in Europe have different happiness patterns.

In particular, immigrants to France do not share the specific unhappiness of native French.

Natives French are less happy than other expatriates in Europe.

This French unhappiness puzzle is not due to language. 
May 2014

\section{Summary}

This article sheds light on the important differences in self-declared happiness across countries of similar affluence. It hinges on the different happiness statements of natives and immigrants in a set of European countries to disentangle the influence of objective circumstances versus psychological and cultural factors. The latter turn out to be of non-negligible importance. In some countries, such as France, they are responsible for the best part of the country's unobserved idiosyncratic source of unhappiness. French natives are less happy than other Europeans, whether they live in France or outside. By contrast, immigrants are not less happy in France than they are elsewhere in Europe, but their happiness fall with the passage of time and generations. I show that these gaps in self-declared happiness have a real emotional counterpart and do not boil down to purely nominal differences.

JEL Codes: I31, H52, J61, O15, O52, Z10

Key-words: Happiness, Unhappiness, Subjective Well-Being, International Comparisons, France, Immigration, European Social Survey. 


\section{Introduction}

Happiness studies have gained so much credit over the last decade that several governments and organizations have endeavored to collect measures of subjective wellbeing to be included in national accounts and used to inform policy (Waldron, 2010, Commission 2009, Eurostat 2010, OECD 2011). Measuring wellbeing "beyond GDP" has become a familiar idea, and subjective wellbeing is one of the main proposed alternative routes. However, targeting an aggregate wellbeing indicator is not straightforward. Although the literature is quite consensual about the correlates of individual happiness, it is much more controversial when it comes to aggregate measures of happiness.

For one thing, whether subjective wellbeing follows the evolution of national income per capita over the long run remains a hotly debated issue among specialists (see Clark and Senik, 2011). International comparisons are also quite puzzling; in particular, it is difficult to fully explain the ranking of countries in terms of subjective wellbeing.

For example, as illustrated by Figures 1.A and 1.B, the poor level of happiness and life satisfaction in France and, to a lower extent, in Germany is not consistent with a ranking of countries based on income per capita or on the Human Development Index, that includes life expectancy at birth and years of schooling. Analyzes of all available international surveys (the European Social Survey, the Euro-Barometer Survey, the World Values Survey, and the World Gallup Poll) lead to a similar conclusion: observable characteristics are not sufficient to explain international differences; in all estimates of life satisfaction or happiness, country fixed-effects always remain highly significant, even after controlling for a large number of macroeconomic and institutional controls (Deaton 2008, Stevenson and Wolfers 2008). The suggestive Figure 2, taken from Inglehart et al. (2008), illustrates the existence of clusters of subjective wellbeing, with LatinAmerica and Scandinavia standing systematically above the regression line, and former communist countries, below. As a rule, France, Germany and Italy rank relatively low, close to Eastern countries. Figures 3.A and 3.B show that international differences in wellbeing are quite 
stable over time: national happiness fluctuates over the business cycle, but the relative positions of the different national happiness and life satisfaction curves remain essentially unchanged.

Several studies suggest that these differences cannot be explained by the structure of wellbeing, i.e. the ingredients of happiness, which are very similar across countries (di Tella et al., 2003). Because France is amongst the countries that rank lower than their wealth would predict, I call this piece of evidence "the French Unhappiness Puzzle", but the puzzle lies more generally in the existence of large, unexplained and persistent country fixed-effects, i.e. international heterogeneity in happiness and life satisfaction.

The reason for these international differences could be that different countries offer different living conditions that cannot be fully arbitraged because of the imperfect mobility of the population across borders. Inside Europe for instance, absent mobility frictions, Europeans would settle into the most attractive places (that offer the highest amenities) and migration flows would lead to the equalization of wellbeing via the adjustment of house prices and wages (Rosen, 1974; Roback, 1982). If this were the case, country fixed-effects would not attract statistically significant coefficients in estimates of subjective wellbeing (Ferreira and Moro, 2010; Luechinger 2009, Oswald and Wu, 2010). However, in actual estimates, they do. This could reflect the existence of obstacles to mobility and other violations of the perfect competition assumptions (rationality, perfect information about local amenities, instantaneous price adjustments, etc.). Hence, country fixed-effects would capture international differences in objective non-monetary local living conditions.

However, another possibility is that happiness does not depend only on extrinsic objective circumstances, but also on people's intrinsic cultural dispositions, mental attitudes and representations. This interpretation points to individual heterogeneity not in terms of preferences for such or such local amenity, but in terms of the happiness function, i.e. the capacity to transform circumstances into wellbeing. Therefore, this paper tries to disentangle extrinsic versus intrinsic factors of happiness, i.e. (i) Circumstances (institutions, regulations and general living conditions that prevail within a country) versus (ii) Mentality (the set of specific intrinsic attitudes, beliefs, ideals and ways of apprehending reality that individuals engrain during their infancy and teenage, via education and socialization instances such as school, peer groups, firms and organizations). Mentality may also be persistent over several generations, hence the term 'culture', which is understood as the set of long-run persistent attitudes, beliefs and values that characterize groups of people. I start with the simplifying assumption that Circumstances and Mentality are separable, and later consider the possibility of their interactions. 
Using a survey of 28 European countries (ESS, waves 1 to 5), I focus on seven countries that have been open to immigration for a long time, to contrast the happiness of natives to that of immigrants. In a given country, say France, natives and immigrants share the same contextual circumstances, but possibly not the same "mentality" or culture. I rely on these commonalities and differences between natives and immigrants of different European countries to identify the nature of national happiness traits. In particular, to the extent to which happiness is due to external circumstances, the pattern of happiness of immigrants in Europe should be the same as that of natives. Bringing this model to the data, I find that the effect of living in a given country inside Europe is not the same for natives and for immigrants. Focusing on France, I show that the idiosyncratic French unhappiness is explained by "Mentality" (in addition to the usual socioeconomic determinants) rather than by extrinsic Circumstances. A set of observations comforts the cultural interpretation of the French unhappiness: French emigrants living abroad are less happy, everything else equal, than are European migrants in average. More generally, the happiness level declared by European expatriates (of the second generation) is correlated to the average happiness of their home-fellows.

Time and generation effects tend to erase cultural differences, but not totally. The level of selfdeclared happiness of second-generation immigrants tends to converge towards that of natives (of their country of residence). Identically, the longer immigrants have sojourned in a given country, the closer their level of happiness gets to that of natives.

I verify that the French unhappiness is not due to language and translation effects, by contrasting different linguistic groups of the population in Belgium, Switzerland and Canada (sampled from the World Values Survey): in Belgium, the francophone Walloons are less happy than the Dutchspeaking Flemish, but this is not true of French-speaking cantons or individuals in Switzerland, nor of the French-speaking Canadians. I also check that measures of short-term emotional wellbeing lead to a similar ranking of countries as subjective happiness. The French unhappiness is also mirrored by a high degree of depressiveness and dissatisfaction of French natives in several domains; again, these negative attitudes are not shared by immigrants.

Overall, these observations suggest that a large share of international heterogeneity in happiness is attributable to cultural attitudes. 


\section{The French depressiveness}

It has now become common knowledge that the French are much less happy and optimistic than their standard of living would predict. This comes in contrast with the French high standard of living, universal and free access to health care, hospitals, public schools and universities, and the high quality of amenities (as attested by the exceptional inflow of tourists). The low level of life satisfaction of the French is not a recent phenomenon; it has been there for as long as statistical series are available (the early 1970's), as illustrated by figure 3.A (based on Eurobarometer surveys ${ }^{1}$ ).

Symmetrically, France obtains high scores in negative dimensions of mental health, such as psychological distress and mental disorders, as measured by internationally recognized medical classifications, such as the International Classification of Disease (ICD10) or the American DSM. These measures of mental stress are generally negatively correlated with subjective wellbeing (Eugloreh, 2007). The high prevalence of depressiveness translates into the exceptionally high consumption of psychoactive drugs (especially anti-depression) by European standards ${ }^{2}$.

If the "French puzzle" is well established, it remains open to interpretation. The persistently high rate of unemployment could be an explanation, but the country fixed-effect remains negative, even after the inclusion of this magnitude in happiness regressions. Algan and Cahuc (2007) have stressed the role of the vicious 'heavy state regulation - low trust - low happiness' nexus. A series of papers by the same authors has stressed the cultural dimension of trust and happiness -and the role of school- in cross-country comparisons. Other explanations based on culture and mentality have pointed to the possible role of lost colonial grandeur (that France shares with Italy and Germany), anti-capitalist preferences (Saint Paul, 2010), the conflict between egalitarian and aristocratic values exacerbated by the highly elitist school system (d'Iribarne, 1989), and the excess of hierarchy in the French society (Brulé and Veenhoven, 2011, Algan et al. 2012). Discussing these interpretations is beyond the scope of this paper, although most of them, especially the latter, are consistent with its findings. Finally, a new paper by Oswald and Proto proposes that cross-country differences in happiness are influenced by genes, in particular the 5-

\footnotetext{
${ }^{1}$ http://ec.europa.eu/public_opinion/description_en.htm

${ }^{2}$ For instance, according to the European Study of the Epidemiology of Mental disorders (ESEMeD, a study of the general population, run in 2001-2003 over 21425 individuals aged 18 and over), France had the highest rate of consumption of psychotropic, before, Spain, Italy, Belgium, the Netherlands and Germany (Briot, 2006).
} 
HTTLPR, i.e. the protein-encoded serotonin transporter gene, which is known to be implicated in human mood.

\section{Related literature}

This paper is not studying the effect of migration on happiness per se; rather it is using migration flows to European countries as an identification strategy. With this respect, it is close to that of Luttmer and Singhal (2011), based on the same ESS survey, who relate immigrants' redistributive preferences to the average preference in their birth countries. Other papers have used migrations flows in order to elicit cultural persistence: Guiso et al. (2006) and Alesina and Giuliano (2011) have shown that country-of-ancestry fixed-effects are significant determinants of preferences for redistribution in the United States. In their studies of women's work behavior and fertility choices, Fernandez and Fogli (2009) have provided rich evidence of the influence of women's ancestors' culture. All these papers characterize culture as inertia, although Fernandez (2007) provides a model of cultural change, embedded in what she calls an 'epidemiological approach'.

There is a small literature on migration and happiness, showing unanimously (and unsurprisingly) that immigrants are less happy than natives, controlling for a series of observable characteristics and circumstances (see Stillman et al. 2012, Bartram 2011, Safi 2010, Baltatescu 2007, or De Jong et al. 2002). Of course, there is a much larger literature on acculturation and cultural transmission of immigrants, which includes, inter alia, Portes and Zhou (1993), Bisin and Verdier (2001, 2011), and Bisin et al. (2004). Finally, an even larger literature focuses on the discrimination of immigrants in their host countries, in particular with regards to labor market integration (see Altonj and Blank, 1999 for a survey). Discrimination is certainly a determinant of happiness, and could vary across countries and depend on the origin of immigrants: this has to be taken into account in the empirical analysis.

Finally, international comparisons of happiness are necessarily related to the large literature that focuses on biases and equivalence between constructs, measures and scales (Van de Vijver 1998, King et al. 2003) ${ }^{3}$. Although an abundant literature suggests that subjective wellbeing is a valid construct that can be reliably measured (see Layard 2005 or Clark et al. 2008 for useful reviews), the question here is whether international differences in happiness are not due to Frame-ofReference Biases (FORB) and general Differential-Item-Functioning (DIF) biases (see ZUMA

\footnotetext{
${ }^{3}$ It should be underlined that the ESS devotes special attention to the translation and comparability of verbal labels across countries (hence a costly process of face-to-face interviews, questionnaire validation, etc.).
} 
1998). However, it is not clear that these "biases" are purely nominal differences that should be treated as misleading measurement errors. Consider, for instance, the case of "social desirability" biases, first underlined by Cronbach (1946): a large literature in psychology, management and sociology has been devoted to identifying these responding biases, and elaborating instruments for correcting them (such as social desirability scales). However, another view has emerged (McCrae and Costa, 1983, Edwards, 1990) proposing that biases are not pure measurement errors, but carry some information and can even constitute personality traits ${ }^{4}$ at the individual level, and cultural traits at the more aggregated country level, and are correlated with subjective wellbeing (Eysenck and Eysenck, 1975). Following this literature, I will interpret international differences not as meaningless anchoring biases and measurement errors, but as identity and cultural traits.

It is fair to mention an appealing recent survey-design technique based on "anchoring vignettes", which is meant to correct for self-assessment biases (King et al. 2004, King and Wand, 2006, Beegle et al. 2009, Kapteyn et al. 2009, Angelini et al. 2009, Hopkins and King, 2010). Subjects are asked to answer questions from the perspective of another person (the vignette), as well as for themselves. Respondents in different countries are asked to evaluate the same vignettes, so that their evaluation should be the same if there were no frame of reference bias. Any variation in the answers given by respondents is then interpreted as an anchoring bias, that researchers can use to rescale happiness measures in order to de-bias them. Two papers are particularly relevant with respect to this one. Kapteyn et al. (2009) introduced randomly assigned vignettes to assess DIF in the self-assessed life satisfaction of Dutch and American respondents. Angelini et al. (2009) used the vignettes of the Survey of Health, Ageing and Retirement in Europe (SHARE) in ten European countries to study life satisfaction. Both found that correcting for the measured bias leads to a reversal in the ranking of countries in terms of happiness. Vignettes-based research is very stimulating and it is getting more space in the social sciences literature. However, it is not clear that anchoring biases evaluated by vignettes should be seen as a pure artefact. If the French evaluate the happiness of some hypothetical person in a less positive manner than the Danes, perhaps it is because they would actually feel less happy in the situation of that hypothetical

\footnotetext{
${ }^{4}$ Two dimensions of social desirability are classically distinguished: self-deception and deliberate deception (heterodeception) (Paulhus, 1984, Tournois, et al. 2009). Self-deception was found to be related with personality traits such as good self-esteem, low anxiety and low neuroticism. Hetero-deception ("faking to look good") in turn, is correlated with extraversion, openness, agreeableness and conscientiousness (Paulhus 1994, Tournois et al. 2009).
} 
person. Again, anchoring biases can be viewed as a cultural but nonetheless integral part of happiness.

My personal stand is thus to consider the cultural dimension of happiness as a reality rather than a nominal illusion. I thereby join Diener and Suh (2000), Diener et al. (2010) and Inglehart et al. (2008) who have stressed the cultural dimensions of international differences in happiness.

The paper is organized as follows: the next section presents the data, Section III the empirical approach, section IV the results and section V concludes.

\section{Data}

The paper uses the five first waves of the European Social Survey (ESS 5 , 2002-2010). I focus on the inhabitants of countries that are traditional immigration countries, and in which immigrants represent at least $15 \%$ of the sampled population. In order to have as many observations per country as possible, I select countries that are surveyed at each of the five waves, and for which the main variables of interest are not missing. This leaves me with 7 countries of residence, i.e. Belgium, Switzerland, Germany, France, Great-Britain, the Netherlands and Sweden, with about 5991 (Belgium) to 8944 (Germany) observations per country in the regression sample (Table A1).

Tables A1 to A7 present the descriptive statistics for the regression sample (estimating happiness on age, gender, (log of) household income, employment status, marital status, broad region of origin, migration status, country of residence and year fixed-effects, as in equation (1) below).

I consider two nested samples: a larger one, that includes immigrants from all countries, and a smaller "European" one, where immigrants come from the 28 European countries of the ESS, i.e. countries of the European Union let alone Island and Romania, for which there is no data, plus Norway and Switzerland (see Table A4). The latter group of immigrant is likely to be more homogenous, hence more adapted to the reasoning of the paper.

In the larger sample (Table A1), amongst the 47,585 observations with no missing value, 38,419 come from natives and 9,166 from immigrants (of which 4,645 first-generation immigrants, 1,352 second-generation immigrants, and 3,136 immigrants of the 1.5 generation) ${ }^{6}$. The smaller, strictly

\footnotetext{
${ }^{5}$ http://www.europeansocialsurvey.org

${ }^{6}$ I call "natives" individuals born in the country where they live and whose both parents were also born in that country. First-generation immigrants are individuals who were born abroad. Second-generation immigrants were
} 
European, sample (Table A2) contains 43,373 observations, count 38,169 natives, 1917 first generation immigrants, 825 second generation immigrants and 2463 immigrants of the 1.5 generation.

Table A3 illustrates the composition of the larger sample in terms of origin and destination countries of migrants. Amongst the 9166 (first and second generation) immigrants established in the 7 European countries under review, 1196 come from Africa, 1794 from Asia or Australasia, 420 from Latin America, 168 from North America; the bulk of immigrants come from other European countries $(5588)^{7}$. Table A4 displays the country of origin of the 2741 European migrants to the seven countries of interest.

\section{Subjective wellbeing measures}

Table A5 shows the descriptive statistics of the main variables used in the analysis. The main variables of interest, subjective happiness (Taking all things together, how happy would you say you are?) is measured on a 0-10 scale, where 0 was labeled 'extremely unhappy' and 10 'extremely happy'. Its average level in the sample is 7.6 , in the range of what is found in other similar surveys.

Together with Life Satisfaction (All things considered, how satisfied are you with your life as a whole nowadays? Please answer using this card, where 0 means extremely dissatisfied and 10 means extremely satisfied), this measure of hedonic wellbeing is the most commonly used in this literature. Both are considered as measures of long-run subjective wellbeing as opposed to more short-run emotions (see below). A paper by Clark and Senik (2012) has documented the very strong resemblance of self-declared Happiness and self-declared Life Satisfaction. The structure of these estimates is extremely similar. For instance, the Spearman correlation coefficient between the estimated parameters of the regressions of Life Satisfaction on the one side and Happiness on the other side is as high as 0.961 .

born in their country of residence to foreign-born parents. I call "1.5 generation immigrants" individuals who were born to one foreign-born parent and one native parent. Because the relative influence of the culture of their origin versus destination country is unclear, I do not use this group for the identification of the cultural dimension of happiness.

\footnotetext{
${ }^{7}$ Some individuals had conflicting information about the country of birth of their parents and their immigration status. In particular, some of them declared that they were immigrants although both their parents were born in France. I dropped these observations form the sample, but I verified that reclassifying them in the most sensible way did not alter the results.
} 
In this paper, I use the 'Happiness' question, which looms larger than the 'Life Satisfaction' question. The latter is often thought to capture a cognitive and judgmental dimension of wellbeing, whereas the formulation in terms of 'Happiness' elicits a mix of cognitive and emotional wellbeing, as individuals who answer the happiness question certainly reflect both on how successful their life is but also on how they generally "feel" in terms of affect and zest (Helliwell et al., 2013). I think it is important to be sure to measure hedonic, and not only cognitive, subjective wellbeing in order to capture experienced utility rather than just decision utility (Kahneman et al. 2004). Indeed, decision utility can be based on false expectations, biased memories and other cognitive errors. But more importantly, measuring experienced utility, i.e. the actual hedonic state of individuals, is precisely the raison-d'etre of the recourse to subjective wellbeing statements, i.e. to provide an alternative indicator, in addition to the usual decisionutility criterion that is used by standard economic analysis.

Hence, for space and clarity reason I chose to display the treatments based on the happiness question. However, estimates of Life Satisfaction are displayed in Table 5 (and E1.A and E1.B in the Electronic Appendix) that replicate the main specification of the estimates on a series of other wellbeing measures and satisfaction domains, such as depressiveness, optimism and economic attitudes.

In the robustness section (Section III), I also recourse to alternative measures of short-run emotional wellbeing in the form of reported affect (Diener et al. 2010, Kahneman et al. 2010). The latter are generally collected using the Experience Sampling Method ${ }^{8}$ or the DayReconstruction-Method ${ }^{9}$, or time-use surveys, where respondents have to qualify the emotions they experience during each of their daily activities. This method is followed by the Gallup World Poll, which conducts surveys of representative samples of people from 155 countries since 2005, asking individuals to report the emotions they experienced during the previous day. Questions are worded as follows: 'Did you experience the following feelings during a lot of the day yesterday? How about ?' Each of seven emotions (smile, enjoyment, happiness, worry, sadness, anger, stress) are reported separately, using yes/no response options.

\footnotetext{
${ }^{8}$ Hektner et al. (2007).

${ }^{9}$ Kahneman et al. (2004).
} 
All the descriptive statistics are weighted using design weights that correct for the composition of each country's national sample ${ }^{10}$.

\section{Empirical strategy}

If the effect of living in a country boiled down to the objective circumstances of that country, and if the latter were experienced in the same way by natives and immigrants, the ranking of countries in terms of happiness would be the same whether evaluated by natives or by immigrants. Then, in estimates of happiness, controlling for the migration status of individuals (native versus immigrant), their country of origin, their socio-demographic features and their country of residence, the coefficient on the interaction terms between country fixed-effects and migration status would not be statistically significant. On the other hand, if the coefficients on these interactions terms are statistically significant, they can be used to decompose country fixedeffects in terms of extrinsic circumstances versus intrinsic psychological attitudes.

The identification strategy relies on the following assumptions: (i) the circumstances of country $j$ are experienced by all its inhabitants in the same way, independently of their geographical origin; (ii) natives differ from immigrants by their 'Mentality' or 'Culture'. I use these differences (between natives and migrants) and double differences (between countries) to identify the share of the country fixed-effects that can be attributed to Circumstances versus Mentality.

I assume that mentality has some cultural inertia that affects immigrants of the first and second generation, and disappears after the second-generation. This cut-point is imposed by the survey, which, as is generally the rule, reports the origin of individuals and of their parents, but not further. This usual convention probably corresponds to the idea that cultural differences take time to dissipate (in the case of the culture of origin) or to acquire (in the case of the culture of the destination country), and vanishes after two generations. In addition to the persistent mentality of immigrants, the estimated coefficients can encompass the specific position of immigrants in society due to selection effects or discrimination.

The case of individuals with one native and one immigrant parent, is less clear-cut. They are likely to be partly influenced by the culture of origin of their immigrant parent, and to have received the cultural capital transmitted by their native parent. In order to avoid making any assumption about the rate of cultural convergence of this generation, I generally do not use them for the

10 See http://essedunet.nsd.uib.no/cms/userguide/weight/ 
identification and drop them from the regression sample (except when doing so would make the sample too small, i.e. Table 3).

I thus estimate a happiness equation on the sample of residents in the seven elicited countries, at the individual level (indexed by i). The general form of this equation is the following:

$H_{\mathrm{ijt}}=\alpha . I+\beta . X_{\mathrm{it}}+\delta_{\mathrm{k}} \cdot \mathrm{O}_{\mathrm{k}}+\tau_{\mathrm{t} \cdot} \cdot T_{\underline{\underline{t}}}+\gamma_{\mathrm{j}} \cdot \mathrm{D}_{j}+\mu_{\mathrm{j}} \cdot \mathrm{I} . \mathrm{D}_{\mathrm{j}}+\varepsilon_{\mathrm{i}}$

where $\mathrm{I}$ is a dummy variable that takes value 1 if the respondent is an immigrant (and 0 otherwise), $D_{j}$ is a dummy variable indicating the country of residence of the respondent $(j=1,7)$, I.D $D_{j}$ is the interaction term between being an immigrant and living in country $j$, and $O_{k}$ is the broad region of origin of the respondent $(k=1,6)$. As shown by Table A3, the sample of immigrants is too small to allow controlling for each country of origin, so that I had to aggregate the latter into larger regions (Africa, Asia-Australasia, Europe, Latin America and the Caribbean, North America). Vector $\mathrm{X}_{\mathrm{it}}$ contains the usual socio-demographic variables (age, age square, marital status, gender, log household income, employment status) that have been shown to influence happiness and to be relevant to the situation of immigrants. The estimates also include year fixed-effects $T_{\underline{\underline{t}}}$ corresponding to the waves of the survey ( $t=2002,2004,2006,2008,2010$ ). Finally, $\varepsilon_{\mathrm{i}}$ is the error term. I do not include education because it is widely recognized that this variable is subject to serious measurement errors when it comes to immigrants, because the education tracks and diplomas are often not fully recognized and valued in migrants' destination country (I verified that including these variables did not change the results).

Estimating a model with country fixed-effects usually implies leaving one of the country dummies out of the regression as a category of reference. However, to facilitate the interpretation and to avoid choosing arbitrarily a country of reference, I recalculate the coefficients of the model so that the effect of living in country $j$ is measured with reference to the average of the sample excluding country $j^{11}$. Hence, I can interpret the coefficient on the "France" dummy as capturing the happiness impact of living in France rather than in the average other European countries of the survey.

\footnotetext{
11 Stata's program devcon transforms the coefficients of $0 / 1$ dummy variables so that they reflect deviations from the "grand mean" rather than deviations from the reference category. The modified coefficients sum up to zero over all categories. devcon reports coefficients for all categories (including the category that was used as the reference category in the original model) and modifies the model's constant accordingly (see Yun, 2003).
} 
Based on equations (1), I can write the average happiness difference that would be experienced by individuals with the same socio-economics features $(X)$ and same origin $\left(\mathrm{O}_{\mathrm{k}}\right)$ (i.e. controlling for these variables), depending on their migration status and country of residence as following:

- the average happiness difference between immigrants in country $j$ versus the Rest of Europe (ROE): $\alpha+\gamma_{j}+\mu_{j}-\alpha=\gamma_{j}+\mu_{j}$

- the share of country j's specific happiness explained by mentality rather than circumstances, i.e. the cross-country difference in the happiness gap between natives and immigrants: $\gamma_{j}-\left(\gamma_{j}+\mu_{j}\right)=-\mu_{j}$

The idiosyncratic happiness difference of native inhabitants of country $j$ as compared to the rest of Europe $\left(\gamma_{i}\right)$ is thus decomposed into the effects of Circumstances $\left(\gamma_{j}+\mu_{i}\right)$ and Mentality $\left(-\mu_{j}\right)$. I retrieve them using on the estimation of the happiness equation (1) at the individual level.

Because the size of the sample does not allow controlling for the country of origin of immigrants, there is a risk that the unobserved heterogeneity between immigrants biases the results, even controlling for their broad region of origin. This would happen for instance, if immigration flows to different countries were driven by different motives attracting different type of people, such as economic opportunities, political oppression or family reasons. Hence, to rely on a (hopefully) more homogenous group of migrants, I run the same exercise on a restricted sample that contains only intra-European migration. Note that here again, the size of the sample does not allow controlling for individuals' country of origin.

I also estimate a specification of equation (1) where I distinguish first-generation and secondgeneration immigrants in each country. In the same line, I introduce in the regression the time span that immigrants have spent in their country of destination.

Beyond this baseline specification, I also execute other decomposition exercises, allowing for the interdependence between the different arguments of the happiness function. In particular, I run Oaxaca-Blinder type simulation and decomposition of the happiness difference between natives and immigrants, as well as between native French and native Belgians.

\section{Results}

Table 1.A displays the estimate of happiness following equation (1) spread on three panels for clarity. The results are in line with the classical findings of the happiness literature in terms of age, 
gender, marital status, household income and employment status. Country fixed-effects are all statistically significant. As explained, the coefficients have been recalculated in order to express the effect of living in a particular country as compared with the rest of Europe in average, so that that they sum up to zero. Immigrants are less happy than natives. Immigrants coming from Asia and Africa are worse off than the average, the opposite holds for those who come from North America.

\section{Main results}

Column (2) displays the coefficients on country fixed-effects, column (3) the coefficient $\left(\boldsymbol{\mu}_{\mathrm{j}}\right)$ on the interaction between country fixed-effects and the fact of being an immigrant (either first or second generation). As explained in section II, parameter $\left(-\mu_{j}\right)$ measures the cultural part of the idiosyncratic national happiness (or unhappiness).

Ceteris paribus, native residents in France, Germany, and Great-Britain are less happy with their life than the average Europeans, in contrast with native inhabitants of Belgium, the Netherlands, Switzerland and Sweden. But, conditionally on being an immigrant, which as such implies a lower happiness (by -0.136), those who have chosen France as a destination country are about as happy as the average immigrant in Europe (controlling for the broad origin of immigrants). Column (3) shows that the French lower happiness is greatly attenuated for immigrants. Based on Table 1.A, one can decompose the idiosyncratic happiness of each country. In Table 1.C, the happiness gap of natives $\left(\gamma_{j}\right)$ is decomposed into the effect of Circumstances $\left(\gamma_{j}+\mu_{j}\right)$, versus Mentality $\left(-\mu_{j}\right)$. Concerning France, the share of the happiness gap (-0.312) that is due to Circumstances is negligible (-0.068) as compared to Mentality (-0.244). This is in contrast with Germany, where the lower level of happiness seems to originate in objective circumstances to a large extent. The role of mentality is also particularly high in the high level of happiness in Switzerland. The same exercises are presented in Tables 1.B and 1.D on the sample restricted to European countries. The results are essentially similar. Table A1 presents a more detailed specification of the same estimate in European countries. It shows that the gap between natives and immigrants in France is twice as large for first-generation immigrants $(0.247)$ than for second-generations immigrants (0.102). The same convergence process is visible for other countries as well, except Belgium.

Going further in this direction, Table 4 explores the role of the passage of time in the acculturation of immigrants. It displays the usual estimate of happiness in which I included the length of time spent by migrants in each country of residence and the interaction between the length and each country. European immigrants who spent more than ten years in France have a 
lower level of happiness than those who chose another European country (by -0.371); for those who have spent more than 20 years in France the level of happiness is lowered by 0.601. By contrast, the effect of having spent longer years in Sweden or Switzerland is positive. This estimate is run on intra-European immigrants only in order to keep the sample homogenous. This restriction is imposed by the important changes in the immigration policy of European countries towards tier countries over the last decades.

Hence, under the assumptions stated in Section II, the specific unhappiness trait of French people seems to be due to their values, beliefs and perception of reality rather than to the country's objective general circumstances. Needless to say that this does not mean that objective circumstances do not explain the level of happiness in France and other European countries. Rather, the lesson is that the unexplained part of the French unhappiness specificity, once the effect of measurable objective sources is taken into account, is essentially of a mental phenomenon.

\section{Additional Accounting}

The results of Table 2 rely on the assumption that the vector $\beta$ of coefficients on circumstances $(\mathrm{X})$ is the same for all groups of the population. In other words, the French cultural specificity is treated as an additive element that shifts the whole happiness function upwards or downwards. However, this constraint can be relaxed, allowing not only the constant (shifter) but also the elements of vector $\beta$, associated with all the determinants of the happiness function, to vary across countries and groups of the population. One can then ask the following question: how happy would French natives be, had they the happiness function of migrants? To enquire, I first estimate a happiness equation for each country and each group of the population (natives/immigrants). I retrieve the $\beta$ coefficients specific to each group and run simulation exercises. Table 2.A shows that if French natives had the typical happiness function of immigrants in France, they would reach an average level of happiness of 7.35 instead of 7.19. In all other countries except Germany, the situation is the reverse and the happiness function of natives is higher than that of immigrants. Table 2.B run the same simulation exercise with a sample restricted to European immigrants. The results are similar.

One can also compare France and Belgium, two neighboring countries sharing a common language: if the French experienced the objective circumstances of their lives with the happiness function of the Belgians, they would reach an average level of happiness of 7.72 instead of their actual level of 7.19. An Oaxaca-Blinder (1973) decomposition of the happiness difference 
between French and Belgian natives (-0,56) indeed attributes 0.507 happiness points on the account of coefficients, versus -0.053 for endowments, and -0.039 for interactions between the two (see Jann 2008) ${ }^{12}$.

One may think that the order of magnitude of these figures is not very impressive, even though they are equivalent, in terms of wellbeing, to a variation by about $2 \%$ in average income, which is approximately the annual growth rate of national income in these countries over the considered period. The small order of magnitude of the parameters is due to the narrow range of variation of self-declared happiness, a general fact that is well known by the specialists of the field (See Clark and Senik 2012). The mentioned variations represent about one quarter of the standard deviation of the happiness variable (1.67). Moreover, as shown by the tables of this paper, in a typical happiness regression, the share of happiness that is explained by observable variables is small; the typical $\mathrm{R}^{2}$ of an OLS estimate of happiness is around $10 \%$ depending on the controls that are included.

\section{The French Abroad}

If it I true that happiness has a persistent cultural dimension, it should be the case that the French (for instance) are less happy than other Europeans in average even when they live in a foreign country. Table 3 shows that among migrants of either generation having moved from one of the 7 European countries under review to another of the 28 European countries surveyed by the ESS, the French are statistically significantly less happy than the average, even controlling for the country of residence. A French origin reduces the level of self-declared happiness by about 0.10. This lower level of happiness of French expatriates is shared by the British and the Belgians. As shown by column 2, the level of happiness is also lower for the children of French emigrants, i.e. people whose one or two parents were born French (second and 1.5 generation emigrants) ${ }^{13}$.

\section{An epidemiological approach}

In Table 3, most coefficients on the country of origin of European migrants are statistically significant, which suggests that the cultural dimension of happiness is important in a general way. To comfort this observation, inspired by Luttmer and Singhal (2011), I tested whether the

\footnotetext{
${ }^{12}$ See the working paper version of this article for the tables reporting the results of these exercises.

13 The number of observations is too small to estimate the equation on second-generation migrants only. The coefficient is correctly signed, but not statistically significant for the first generation of immigrants to France.
} 
happiness of European migrants of the second generation is correlated with the average happiness of their ascendants in their origin country. To be conservative I consider only migrants within Europe. Both T test and Spearman test lead to the rejection of the hypothesis that the happiness of migrants is independent or has a different mean value from that of their compatriots in their home country. When the average level of happiness of one's home fellows (natives) is introduced in the estimate of her own happiness (following the specification of equation (1) as usual), it attracts a partial correlation coefficient of 0.248 (0.001), controlling for the usual socio-demographic conditions as well as country of origin an destination, and clustering for the country of residence. This "epidemiological" result can be interpreted, in the spirit of Luttmer and Singhal, as testifying to the cultural dimension of happiness.

\section{Life Satisfaction and other Attitudes}

If the lower happiness of the native French is not due to circumstances but to the way they perceive them, this should also appear in the other attitudes and values that they endorse. Table 5 presents estimates of a series of wellbeing and domain satisfaction measures. The upper panel contains regressions estimated on the sample of natives and immigrants from the whole world; the lower panel presents the same estimates run on a sample restricted to European immigrants. Because the entire table is extremely long, it is presented in the electronic Appendix (Table E1.A and E1.B). Table 5 contains an extraction of these longer tables showing the coefficients on the French dummies and interaction terms.

The first column of each of these tables displays an estimate of a depressiveness score (column 1), built with questions of the third wave of the ESS (hence the smaller number of observations) that were inspired by the well-known CES-Depression scale (Radloff 1977). These questions asked the respondent how often, during the past week, he 'felt depressed', 'felt everything he did was effort', 'sleep was restless', 'felt lonely', 'felt sad', 'could not get going', 'felt anxious', 'felt tired', 'felt bored', 'felt rested when woke up in morning', 'seldom time to do things he really enjoy', 'feel accomplishment from what he did', in general feel very positive about oneself, 'always optimistic about one's future', 'at times feel as if he is a failure', choosing an answer on a scale going from 1 'none or almost none of the time', 2 'some of the time', 3 'most of the time', 4 'all or almost all of the time'. (I recoded the scales in order to obtain a score that increases with depression symptoms). By summing up the number of points on these different questions, I obtain an index of depressiveness that runs potentially from 5 to 59 . In the regression sample, it takes values from 5 to 57 , with an average value of about 20. France has a score of 22 , in the vicinity of Portugal and Great-Britain. 
Tables 5.A and 5.B offer several lessons. Concentrating on the French again, it appears that French natives are more depressed than the average European; they are also less satisfied with their life, as well as on all the dimensions measured by the survey, except satisfaction with the health system (see also Deaton, 2008, Figure 5 p. 68, for a similar finding). They are much less satisfied than the average native Europeans with the state of the economy in the country, with the government, with state of democracy, and with the state of the education system. They are less likely to estimate that they "live comfortably on their income" and are particularly prone to declare that 'life is getting worse for most people in the country' and that 'it is difficult to be bopeful for the future of the world'. The specific unhappiness of the French is thus mirrored by a general pessimism concerning their perspectives.

Beyond the case of France, Germany and Great-Britain form a group of dissatisfied countries, although the phenomenon is not as intense or systematic in the case of the two latter. By contrast, the Swiss and the Swedes are generally more satisfied and optimistic than the average Europeans.

However, the pattern of satisfaction among immigrants is not the same, as illustrated, in the second and third panel of the table, by the coefficients on the interactions between country fixedeffects and dummies coding for immigrant (of the first or second generations). In the case of France, almost all of these coefficients have an opposite sign as those on country dummies (natives), talking to the importance of mentality in the attitudes of natives.

\section{Robustness}

Are international differences in self-declared happiness reflecting actual latent differences in wellbeing or purely nominal differences? To answer, I use two pieces of evidence: (1) measures of emotional well-being à la Kahneman, and (2) the case of multi-linguistic countries. I then discuss the assumption of separability between migration status and individual circumstances that is used for identification in the previous section.

\section{Emotional well-being}

It is useful to check whether alternative measures of well-being that focus on short-run emotions and affect lead to a similar picture of the French in the hierarchy of European nations. I used the 
country mean frequency of reported affect for the same European countries as analyzed in the rest of the paper, for years going from 2007 to $2009^{14}$.

As shown by Figures 4.A and 4.B, it turns out that France ranks first in terms of negative affect and last in terms of positive affect! This is driven by the particularly high number of French respondents reporting feelings of anger and worry and the low frequency of feelings of enjoyment and happiness. By contrast, Sweden scores particularly high in terms of enjoyment and low for worry, sadness and angriness (see the descriptive statistics in Table A5).

Hence, measures of emotional well-being, which capture experienced affect and are thus less subject to nominal biases than happiness or life satisfaction judgments, lead to the same picture of international differences as the latter, and in particular to the same assessment of the French unhappiness.

\section{Language: culture or scaling}

Country fixed-effects could also be due to language and translation effects, if happiness statements depend on the language in which they are expressed, or if different nations associate a different verbal label to a given feeling. Country fixed-effects would then boil down to purely nominal scaling effects. To address this issue, I study the typical happiness of different linguistic groups inside three multilingual countries. If the French unhappiness is purely nominal, then, within a given country, francophone regions and individuals should declare a lower happiness than non-francophone ones.

Using the ESS, I look at the case of Belgium and Switzerland (about 6000 observations each). In Belgium, three regions are distinguished: Wallonia, Flanders and Brussels. Table 6.A shows that controlling for the usual socio-economic circumstances (age, gender, income, unemployment, marital status), as well as for year dummies (which account for the business cycle), and controlling for the regions where they live (column 1) or not (column 2), francophone individuals are less happy than Dutch-speaking ones (by about 0.3 happiness points). However, in Switzerland it is not the case that French-speaking individuals are less happy. Table 6.B shows that it is the Italian-speakers who are statistically significantly less happy than the Germanspeakers and the French-speakers. Controlling for the regional language or not, French-speakers appear to be just as happy as German-speakers.

\footnotetext{
${ }^{14}$ I am grateful to Angus Deaton for obtaining the authorization for me to use these data.
} 
I also used the Canadian sample of the World Values Survey available for years 2000 and 2006 (3461 observations, see descriptive statistics in Table A6). The data include information about the language in which the interview was realized, and the language that people declare they use predominantly at home. In this survey, 68\% of respondents declared English as their home language, 26\% French and 5\% another language. Table 6.C shows that francophone individuals are happier than English-speaking ones (by about 0.05 points), controlling for a series of objective circumstances, such as the usual socio-demographic features, year fixed-effects and the self-declared ethnic group of respondents.

I take these observations as a sign that the difference in the level of happiness of the French is cultural ${ }^{15}$, but not purely nominal.

\section{Omitted variables}

The essential element of the identification strategy is the differential happiness effect of common circumstances across different population groups (natives versus migrants). I thus need to be sure to compare the comparable.

First, the specific happiness trait of the French could be due to some macroeconomic circumstances that are poorly measured at the individual level. I thus included successively in the estimates of happiness the growth rate of GDP, the unemployment rate, the inflation rate, the yearly GDP per capita, the number of worked hours per week, life expectancy at birth, as well as the weight of government expenditure over GDP (taken from the World Bank's World Development Indicators). Including these did not change the magnitude or sign of the coefficients on country and origin dummies and their interactions.

Beyond this basic verification, one needs to address the potential unobserved heterogeneity in the sources of wellbeing of migrants versus natives. Migrants to different countries could have different characteristics that, themselves, have different effects on happiness across countries.

\footnotetext{
${ }^{15}$ Brügger, et al. (2009) and Eugster etl al. (2011) have advocated the importance of cultural differences, as vehicled or expressed by linguistic barriers. They show that preferences for leisure and for insurance against health and labour shocks differ on either parts of the linguistic barrier in Switzerland (the Barrière des Roesties or Röstigraben) that separates German-speaking regions from regions speaking languages derived from Latin (French, Romansh and Italian). They argue forcefully that the observed differences are due to cultural inertia rather than objective circumstances of the regional labor markets.
} 
Migrants could also self-select to different countries depending on some macroeconomic differences (the size of budget transfers for instance).

In the absence of the ideal dataset (that would ensue from a randomized allocation of immigrants to European countries), I can only try to overcome these problems by controlling for the potential sources of heterogeneity that are observable. I thus ran several robustness tests that consist in including triple interaction terms between magnitudes that are suspected of being interdependent (together with main effects and simple interactions), i.e. migration status, destination country and a series of variables of interest. The latter included macroeconomic magnitudes, such as the rate of unemployment and the share of government expenditure over GDP, and individual characteristics such as age, income, employment status and the fact of receiving state transfers.

It turned out that these triple interactions were either statistically insignificant or not signed in the expected way. Overall, most of these tests did not allow rejecting the null hypothesis of separability between the happiness effect of the migration status of respondents and their individual and aggregate circumstances. For space reasons, I do not include these regressions in this version of the paper, but they can be found in the earlier working paper version ${ }^{16}$.

Finally, in this version of the paper, each of the estimates was run both on the sample of all inhabitants in the seven countries of interest, and on a smaller sample restricted to natives and European immigrants. The second specification was intended to minimize the aforementioned risk of unobserved heterogeneity.

\section{Conclusions}

This paper has devoted a special attention to France, which appears as an outlier in international studies of happiness. However, beyond the case of France, it underlines the important cultural dimension of happiness, where culture is understood as a real and not a purely nominal phenomenon. The lesson is relevant for policy-makers who have recently endeavored to maximize national wellbeing and not only income per capita. "Happiness policies" should take into account the irreducible influence of psychological and cultural factors. As those are at least partly acquired in school and other early socialization instances, this points to some new aspects of public policy such as considering the qualitative aspects of the education system.

${ }^{16}$ http:/ / halshs.archives-ouvertes.fr/docs/00/62/88/37/PDF/wp201134.pdf 
Investigating the causes of the differences in the cultural dimension of happiness across countries is beyond the objectives of this paper, but certainly constitutes an interesting avenue for future research. The economics of culture could help understanding how idiosyncratic happiness originates in national institutions and history. The cultural dimension of happiness is also undoubtedly the opportunity for a fruitful encounter between economics and psychology.

\section{Acknowledgements}

I thank Marc Gurgand, Andrew Oswald and Katia Zhuravskaya for discussions and comments on the paper, as well as participants in the OECD New Directions in Welfare Conference (Paris, 2011); the IZA Workshop: Sources of Welfare and Well-Being (Bonn, 2011), the Paris School of Economics seminars, and the Royal Economic Society Conference (London, 2013). I am also indebted to the two reviewers of this paper. I am grateful to Hélène Blake and Sarah Flèche for precious research assistance, as well as to Mariya Aleksynska for her participation in another related project, which has greatly contributed to prepare this one. I thank CEPREMAP for financial support as well as the French National Research Agency, through the Program Investissements d'Avenir, ANR-10--LABX_93-01. All errors are mine.

\section{References}

Alesina, A. and Giuliano P. (2011). "Preferences for Redistribution," in Benhabib J., Bisin A. and O’Jackson M. (eds.) Handbook of Social Economics, 93-132.

Algan Y. and Cahuc P. (2007). La société de défiance : comment le modèle social français s'autodétruit? Paris: ed. ENS rue d'Ulm, 102 p. Opuscule nº - ISBN 978-7288-0396-5.

Algan Y., Cahuc P. and Zylberberg P. (2012). La Fabrique de la Défiance, Albin Michel.

Altonj J., Blank R. (1999). "Race and gender in the Labor Market". Chapter 48, Handbook of Labor Economics, volume 3. 
Amit, K. (2010). "Determinants of life satisfaction among immigrants from Western countries and from the FSU in Israel". Social Indicators Research.

Baltatescu, S. (2007). "Central and Eastern Europeans migrants 'subjective quality of life: a comparative study". Journal of identity and migration studies, 1(2), 67-81

Bartram D. (2011) 'Economic Migration and Happiness: Comparing Immigrants' and Natives' Happiness Gains from Income”, Social Indicators Research.

Beegle K., Himelein K. and Ravallion M. (2009). "Frame-of-reference bias in subjective welfare regressions". World Bank Policy Research Working Paper 4904.

Bisin A. and Verdier T. (2001). "The Economics of Cultural Transmission and the Dynamics of Preferences". Journal of Economic Theory 97:298-319.

Bisin A. and Verdier T. (2011). "The economics of cultural transmission and socialization", in Benhabib J., Bisin A. and O'Jackson M. eds. Handbook of Social Economics, 339-416.

Bisin A., G. Topa and Verdier T. (2004). "Religious Intermarriage and Socialization in the US", Journal of Political Economy, 112, 615-665.

Blinder A. (1973). "Wage Discrimination: reduced Form and Structural Estimates". The Journal of Human Resources 8: 436:455.

Briot M. (2006). Office parlementaire d'évaluation des politques de santé. Sur le bon usage des medicaments psychotropes. http://www.assemblee-nationale.fr/12/pdf/rap-off/i3187.pdf

Brügger B., Lalive R. and Zweimüller J. (2008). "Does Culture Affect Unemployment? Evidence from the Barrière des Roestis", mimeo.

Brulé G., Veenhoven R. (2012). "Why are Latin Europeans less happy? The impact of social hierarchy", Polyphonic Anthropology-Theoretical and Empirical Cross-Cultural Fieldwork. ISBN 978-95351-0418-6.

Clark A. and Senik C. (2011). "Is Happiness Different From Flourishing? Cross-Country Evidence from the ESS". Revue d'économie politique, numéro spécial «Les nouveaux indicateurs de bien-être », (1), 17-34.

Clark A. and Senik C. (2012). "Will GDP Growth Increase Happiness in Developing Countries?" Volume of the 8th AFD-EUDN Conference: Measure for Measure. How Well do we Measure Development? 2012. Paris: STIN, pp. 99-176.

Clark, A., Frijters, P., and Shields, M. (2008). "Relative Income, Happiness and Utility: An Explanation for the Easterlin Paradox and Other Puzzles". Journal of Economic Literature, 46, 95144.

Commission of the European Communities (2009). GDP and Beyond. Measuring progress in a Changing World. Communication from the Commission to the Council and the European Parliament.

Cronbach L. (1946). "Response set and test validity". Educational and Psychological Measurement, 6, 475-794. 
Crowne D. and Marlowe D. (1960). "A new scale of social desirability independent of psychopathology". Journal of Consulting Psychology, 24(4), 349-354.

d'Iribarne P. (1989). La logique de l'honneur, Seuil.

De Jong, G.F., Chamratrithirong, A., Tran, Q.-G (2002). "For better, for worse: life satisfaction consequences of migration". International Migration Review, 36(3), 838-63

Deaton A. (2008). "Income, Health, and Well-Being around the World: Evidence from the Gallup World Poll”. Journal of Economic Perspectives, 22(2), 53-72.

Di Tella, R., MacCulloch, R.J., and Oswald, A.J. (2003). "The Macroeconomics of Happiness". Review of Economics and Statistics, 85, 809-827.

Diener E., Helliwell J. and Kahneman D. (2010). International Differences in Well-Being. Oxford University Press.

Diener E., Kahneman D., Tov W. and Arora R. (2010). “Income's association with Judgements of Life versus Feelings", Chapter 1 (pp 3-16) in Diener E., Helliwell J. and Kahneman D. eds. International Differences in Well-Being. Oxford University Press.

Diener, E., Suh, E. M. (Eds.). (2000). Culture and Subjective Well-Being Cambridge, MA: MIT Press.

EC (2004). The State of Mental Health in the European Union, European Communities, ISBN 92-894$8320-2$

Edwards A. (1990). "Construct validity and social desirability". American Psychologist, 45, 287-289.

Eugloreh (2007). Global Report on the Status of Health in the European Union. http://www.eugloreh.it/ActionPagina_979.do

Eugster B., Lalive R., Steinhauer A. and Zweimüller J. (2011). "The Demand for Social Insurance: Does Culture Matter? ”. The Economic Journal, 121(556), F413-F448.

Eurostat (2010). Feasibility study for Well-Being Indicators.

Eysenck H and Eysenck S. (1975). Manual of the Eysenck Personality Questionnaire. London: Holder and Stoughton.

Fernández R. (2007). "Women, Work, and Culture," Journal of the European Economic Association, 5(2-3): 305-332.

Fernandez R. and Fogli A. (2009). "Culture: An Empirical Investigation of Beliefs, Work, and Fertility", American Economic Journal: Macroeconomics.

Ferreira S. and Moro M. (2010). "On the Use of Subjective Well-Being Data for Environmental Valuation”, Environmental Resources Economics, 46, 249-273.

Guiso L., Sapienza P. and Zingales L. (2006). "Does Culture Affect Economic Outcomes?", Journal of Economic Perspectives, 20(2): 23-48.

Helliwell J., Layard R. and Sachs J. (2013). World Happiness Report, United Nations. 
Heston A., Summers R. et Aten B. (2009). Penn World Table Version 7.0 Center for International Comparisons of Production, Income and Prices at the University of Pennsylvania. (2011).

Hopkins D. and King G. (2010). "Improving anchoring vignettes: designing surveys to correct interpersonal incomparability", mimeo, Harvard University.

Inglehart, R., Foa, R., Peterson, C., and Welzel, C. (2008). "Development, Freedom, and Rising Happiness: A Global Perspective (1981-2007)". Perspectives on Psychological Science, 3, 264-285.

Jann B. (2008). "The Blinder-Oaxaca decomposition for linear regression models", Stata Journal $8(4)$.

Kahneman D., Krueger A., Schkade D., Schwarz N. and Stone A. (2004). "Toward National Well-Being Accounts". American Economic Review, 94, (2), 429-434.

Kahneman E., Schkade D., Fischler D., Krueger A. and Krilla A. (2010.) "The Structure of WellBeing in Two Cities: Life Satisfaction and Experienced Happiness in Columbus, Ohio, and Rennes, France", Chapter 2 (pp 16-34) in Diener E., Helliwell J. and Kahneman D. eds. International Differences in Well-Being. Oxford University Press.

Kahneman, D. and A.B. Krueger (2006). "Developments in the Measurement of Subjective Wellbeing", Journal of Economic Perspectives, 22, 3-24.

Kapteyn A., Smith J. and Van Soest A. (2007). "Vignettes and self-reported work disability in the US and the Netherlands". American Economic Review, 87(1), 461-473.

Kapteyn A., Smith J. and Van Soest A. (2008). "Comparing Life Satisfaction”. Working Paper WR-623, Rand Corporation.

King G., Murray C., Salomon J. and Tandon A. (2003). "Enhancing the validity and cross-cultural comparability of measurement in survey research". The American Political Science Review, 97(4), 567583.

Layard, R. (2005). Happiness: Lessons from a new science. London: Penguin.

Luenchinger S. (2009). "Valuing air quality using the Life Satisfaction Approach", The Economic Journal, 119, 482-515.

Luttmer E. and Singhal M. (2011). "Culture, Context, and the Taste for Redistribution", American Economic Journal: Economic Policy, 3(1):157-79.

McCrae R and Costa P. (1983). "Social desirability scales: more substance than style". Journal of Consulting and Clinical Psychology, 51, 1349-1364.

OECD (2011). How's Life?: Measuring well-being, OECD Publishing. http://dx.doi.org/10.1787/9789264121164-en

Oswald A. and Proto E. (2013). "National Happiness and Genetic Distance”, mimeo.

Oswald A. and Wu S. (2010). "Objective Confirmation of Subjective Measures of Human WellBeing: Evidence from the U.S.A.", Science, 327(5965), 576-579. 
Paulhus D. (1984). "Two-Component Models of Socially Desirable Responding". Journal of Personality and Social Psychology, 46(2), 598-609.

Paulhus D. (1994). Balanced Inventory of desirable responding. Reference manual for BIDR version 6. Vancouver: University of British Columbia, Mimeo.

Portes, A. and M. Zhou (1993), "The New Second Generation: Segmented Assimilation and Its Variants". Annals of the American Academy of Political and Social Science 530:74-96.

Radloff, L. S. (1977). "The CES-D scale: A self-report depression scale for research in the general population”. Applied Psychological Measurement, 1, 385-401.

Roback. J. (1982). "Wages, Rents and the Quality of Life”. Journal of Political Economy, 90(6), 12571278.

Rosen S. (1974). "Hedonic Prices and Implicit Markets: Product Differentiation in Pure Competition", Journal of Political Economy, 82(1), 34-55.

Safi, M. (2010). "Immigrants' life satisfaction in Europe: between assimilation and discrimination". European Sociological Review vol. 26(2), 159-176

Saint-Paul G. (2010). "Endogenous Indoctrination: Occupational Choice, the Evolution of Beliefs, and the Political Economy of Reform”, The Economic Journal, 120 (544), 325-353.

Saris W. (1998). "The effect of measurement error in cross-cultural research". ZUMA Nachrichten Spezial, 67-83.

Stiglitz J., Sen A. and Fitoussi J-P (2009). Report by the Commission on the Measurement of Economic Performance and Social Progress. OECD.

Stillman S., Gibson J., McKenzie D. and Rohorua H. (2012). "Miserable Migrants? Natural Experiment Evidence on International Migration and Objective and Subjective Well-Being", IZA DP 6871.

Van de Vijver F. (1998). "Towards a theory of bias and equivalence". ZUMA Nachrichten Spezial, 1-40.

Van Soest A., Delaney L., Harmon C., Kapteyn A. and Smith J. (2007). "Validating the use of vignettes for subjective threshold scales". Geary WP/14/2007.

Waldron S. (2010). "Measuring Subjective Well-Being in the UK", Office for National Statistics Working Paper.

Wolfers, J. and B. Stevenson (2008). "Economic Growth and Subjective Well-Being: Reassessing the Easterlin Paradox", Brookings Papers on Economic Activity, Spring.

Yun, M.-S. (2003). "A Simple Solution to the Identification Problem in Detailed Wage Decompositions". IZA Discussion Paper No. 836.

ZUMA (1998). Nachrichten Special (special issue dedicated to cross-cultural research and equivalence problems). 


\section{Tables and Figures}

Figure 1.A Happiness, Life Satisfaction and GDP per capita (2002-2010)
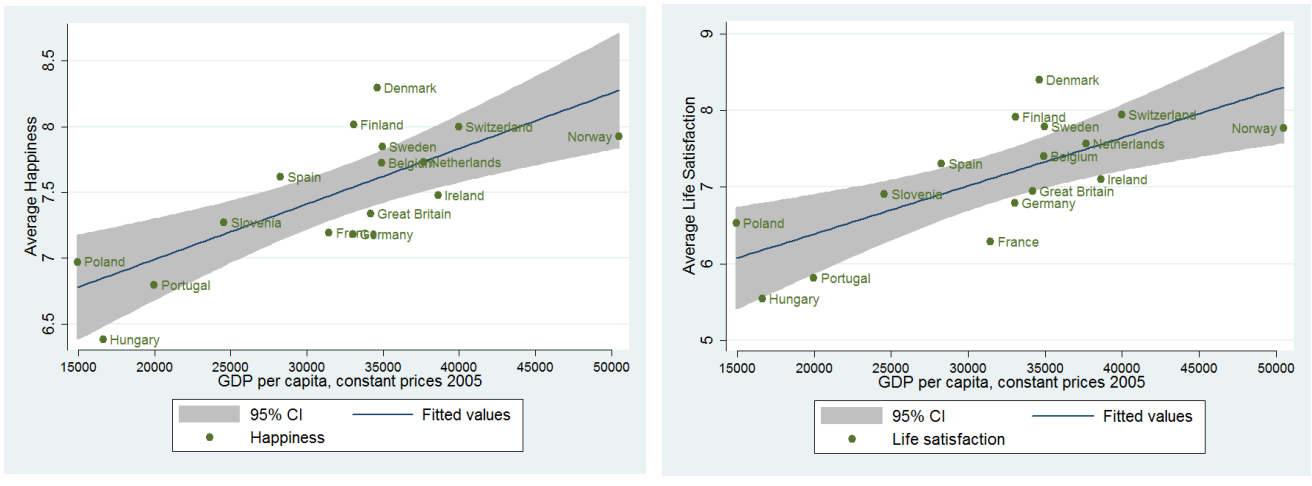

Happiness and Life Satisfaction are measured on a 0-10 scale

Figure 1.B Happiness, Life Satisfaction and the HDI (2002-2010)
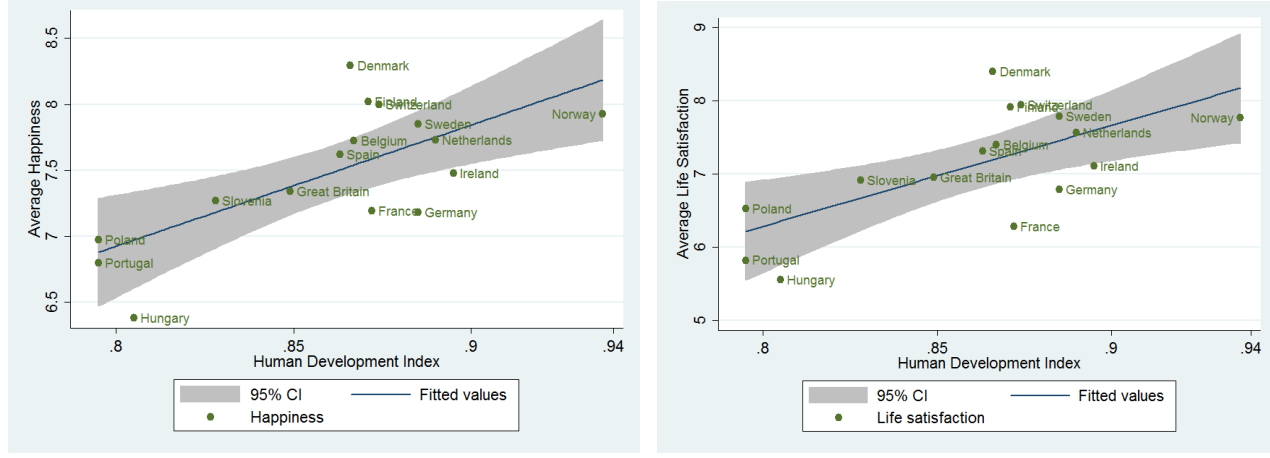

Happiness and Life Satisfaction are measured on a 0-10 scale 
Figure 2. Happiness, Income ... and Cultural Factors around the World

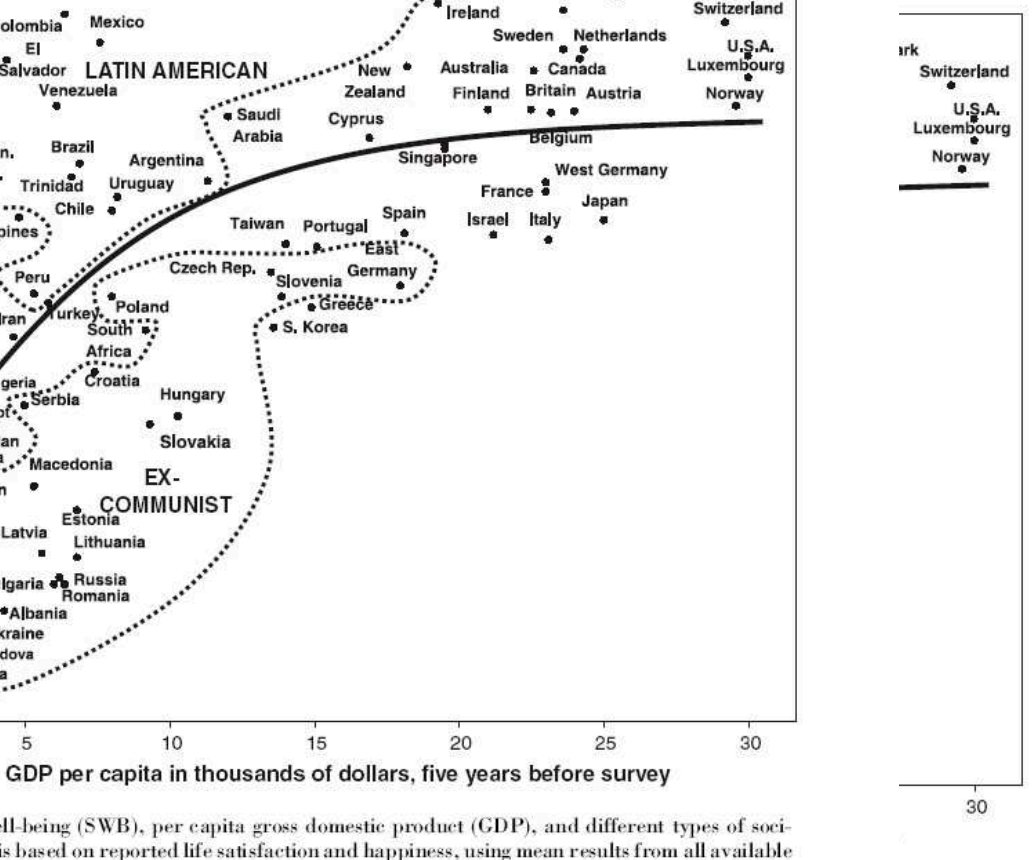

Fig. 2. Subjective well-being (SWB), per capita gross domestic product (GDP), and different types of societies. Well-being index is based on reported life satisfaction and happiness, using mean results from all available surveys conducted 1995-2007 (cubic curve plotted; $r=.62$ ). PPP=purchasing power parity estimates.

Source : Inglehart, Foa, Peterson, Welzel (2008), p. 269

Figure 3.A The Evolution of Average Life Satisfaction Over Time (Eurobarometer)

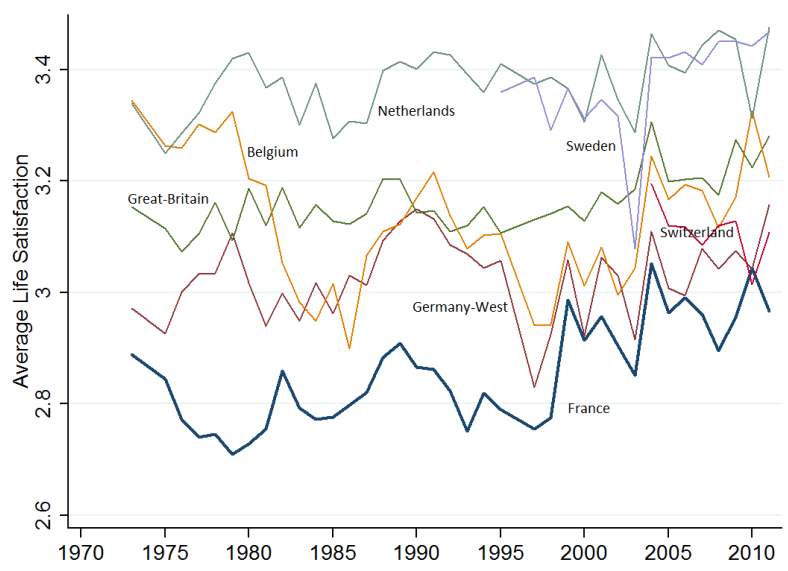

Source: Eurobarometer. Life satisfaction (1-4 scale). 
Figure 3.B The Evolution of Average Happiness Over Time (European Social Survey)

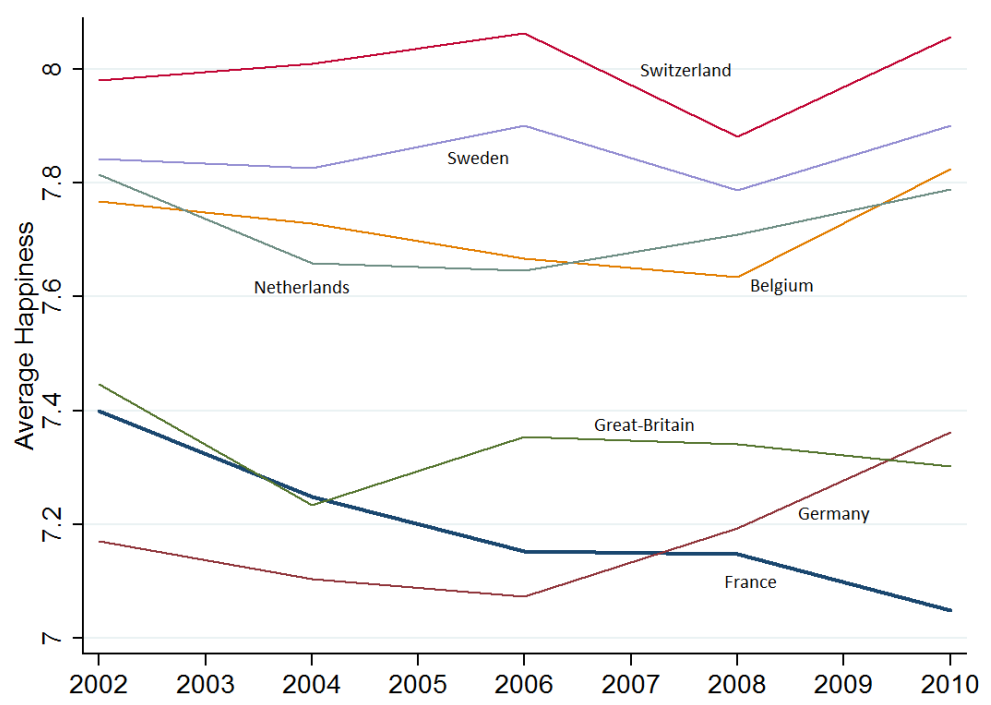

Source: European Social Survey (2002-2010). Happiness (0-10 scale) 
Table 1.A. Estimation of Happiness following Equation (1). Whole sample.

\begin{tabular}{|c|c|c|c|c|}
\hline & \multicolumn{2}{|l|}{ (1) } & \multirow{2}{*}{$\begin{array}{l}(2) \\
\text { Natives } \\
\left(\gamma_{j}\right)\end{array}$} & \multirow{2}{*}{$\begin{array}{l}(3) \\
\text { Immigrants } \\
\left(\mu_{\mathrm{j}}\right)\end{array}$} \\
\hline Happiness & & & & \\
\hline Age of respondent & $\begin{array}{l}-0.0724 * * * \\
(0.0103)\end{array}$ & Belgium & $\begin{array}{l}0.185^{* * *} \\
(0.00952)\end{array}$ & $\begin{array}{l}-0.0735^{* * *} \\
(0.00578)\end{array}$ \\
\hline Age squared /100 & $\begin{array}{l}0.0749 * * * \\
(0.0130)\end{array}$ & Switzerland & $\begin{array}{l}0.259 * * * \\
(0.0235)\end{array}$ & $\begin{array}{l}-0.161 * * * \\
(0.0149)\end{array}$ \\
\hline Male & $\begin{array}{l}-0.149 * * * \\
(0.0169)\end{array}$ & Germany & $\begin{array}{l}-0.321 * * * \\
(0.00797)\end{array}$ & $\begin{array}{l}0.0373^{*} \\
(0.0157)\end{array}$ \\
\hline Reference: Single & & France & $-0.312 * * *$ & $0.244 * * *$ \\
\hline Married & $\begin{array}{l}0.465^{* * *} \\
(0.0288)\end{array}$ & Great-Britain & $\begin{array}{l}(0.00706) \\
-0.217^{* * *}\end{array}$ & $\begin{array}{l}(0.0284) \\
-0.0249 *\end{array}$ \\
\hline Divorced & $\begin{array}{l}-0.142 * \\
(0.0650)\end{array}$ & Netherlands & $\begin{array}{l}(0.00405) \\
0.130^{* * *}\end{array}$ & $\begin{array}{l}(0.0105) \\
0.0473^{* *}\end{array}$ \\
\hline Widowed & $\begin{array}{l}-0.391 * * * \\
(0.0888)\end{array}$ & Sweden & $\begin{array}{l}(0.00324) \\
0.275^{* * *}\end{array}$ & $\begin{array}{l}(0.0138) \\
-0.0696^{* * *}\end{array}$ \\
\hline log household income & $\begin{array}{l}0.358^{* * *} \\
(0.0460)\end{array}$ & & $(0.00313)$ & $(0.0131)$ \\
\hline Unemployed & $\begin{array}{l}-0.671 * * * \\
(0.111)\end{array}$ & & & \\
\hline Immigrant & $\begin{array}{l}-0.136^{* * *} \\
(0.0218)\end{array}$ & & & \\
\hline Region of Origin & & & & \\
\hline Europe & $\begin{array}{l}0.0326 \\
(0.0297)\end{array}$ & & & \\
\hline Africa & $\begin{array}{l}-0.0582 \\
(0.0854)\end{array}$ & & & \\
\hline Asia-Australasia & $\begin{array}{l}-0.168^{* *} \\
(0.0506)\end{array}$ & & & \\
\hline North America & $\begin{array}{l}0.251 * * \\
(0.0723)\end{array}$ & & & \\
\hline Latin America & $\begin{array}{l}-0.0567 \\
(0.0563)\end{array}$ & & & \\
\hline Reference: 2002 & & & & \\
\hline 2004 & $\begin{array}{l}-0.0466^{*} \\
(0.0222)\end{array}$ & & & \\
\hline 2006 & $\begin{array}{l}-0.0840^{*} \\
(0.0351)\end{array}$ & & & \\
\hline 2008 & $\begin{array}{l}-0.100^{* *} \\
(0.0355)\end{array}$ & & & \\
\hline 2010 & $\begin{array}{l}0.0276 \\
(0.0466)\end{array}$ & & & \\
\hline Constant & $\begin{array}{l}6.378^{* * *} \\
(0.271)\end{array}$ & & & \\
\hline Observations & 47.585 & & & \\
\hline R-squared & 0.105 & & & \\
\hline
\end{tabular}


Table 1B. Estimates of Happiness. Immigrants from Europe Only.

$H_{\mathrm{ijt}}=\alpha . \mathrm{I}+\beta \cdot X_{\mathrm{it}}+\tau \cdot \mathrm{T}_{\underline{\underline{t}}}+\gamma_{j} \cdot D_{\mathrm{j}}+\mu_{\mathrm{j}} \cdot \mathrm{I} . \mathrm{D}_{\mathrm{j}}+\varepsilon_{\mathrm{it}}$

\begin{tabular}{|c|c|c|c|c|}
\hline & $(1)$ & & $(2)$ & (3) \\
\hline Happiness & & & Natives & $\begin{array}{c}\text { Immigrants } \\
\left(\mu_{\mathrm{j}}\right)\end{array}$ \\
\hline Age & $\begin{array}{l}-0.0717^{* * *} \\
(0.0111)\end{array}$ & Belgium & $\begin{array}{l}0.187^{* * *} \\
(0.0111)\end{array}$ & $\begin{array}{l}-0.00439 \\
(0.0051)\end{array}$ \\
\hline Age square/100 & $\begin{array}{l}0.0746^{* * *} \\
(0.0139)\end{array}$ & Switzerland & $\begin{array}{l}0.258^{* * *} \\
(0.0266)\end{array}$ & $\begin{array}{l}-0.0993^{* * *} \\
(0.0068)\end{array}$ \\
\hline Male & $\begin{array}{l}-0.154^{* * *} \\
(0.0176)\end{array}$ & Germany & $\begin{array}{l}-0.322^{* * *} \\
(0.00857)\end{array}$ & $\begin{array}{l}0.0526 * * * \\
(0.0035)\end{array}$ \\
\hline $\begin{array}{l}\text { Reference: Single } \\
\text { Married }\end{array}$ & $0.466^{* * *}$ & France & $\begin{array}{l}-0.311 * * * \\
(0.008)\end{array}$ & $\begin{array}{l}0.203 * * * \\
(0.0071)\end{array}$ \\
\hline Divorced & $\begin{array}{l}(0.0290) \\
-0.143^{*} \\
(0.0621)\end{array}$ & $\begin{array}{l}\text { Great-Britain } \\
\text { Netherlands }\end{array}$ & $\begin{array}{l}-0.215^{* * *} \\
(0.004) \\
0.127^{* * *}\end{array}$ & $\begin{array}{l}-0.0958^{* * *} \\
(0.0062) \\
-0.0236^{* * *}\end{array}$ \\
\hline Widowed & $\begin{array}{l}-0.403 * * * \\
(0.0888)\end{array}$ & Sweden & $\begin{array}{l}(0.0039) \\
0.274^{* * *}\end{array}$ & $\begin{array}{l}(0.0044) \\
-0.0329 * * *\end{array}$ \\
\hline log Household income & $\begin{array}{l}0.360 * * * \\
(0.0520)\end{array}$ & & $(0.0035)$ & $(0.0021)$ \\
\hline Unemployed (versus in paid job) & $\begin{array}{l}-0.686^{* * * *} \\
(0.119)\end{array}$ & & & \\
\hline Immigrant (1st or 2 nd generation) & $\begin{array}{l}-0.0811 * * * \\
(0.00777)\end{array}$ & & & \\
\hline Year (ref: 2002) & & & & \\
\hline 2004 & $\begin{array}{l}-0.0666 * * \\
(0.0266)\end{array}$ & & & \\
\hline 2006 & $\begin{array}{c}-0.0952^{*} \\
(0.0410)\end{array}$ & & & \\
\hline 2008 & $\begin{array}{l}-0.112^{* *} \\
(0.0371)\end{array}$ & & & \\
\hline 2010 & $\begin{array}{l}0.00306 \\
(0.0582)\end{array}$ & & & \\
\hline Constant & $\begin{array}{l}6.319 * * * \\
(0.296)\end{array}$ & & & \\
\hline Observations & 43.367 & & & \\
\hline R-squared & 0.108 & & & \\
\hline
\end{tabular}

Cluster (country of residence). The coefficients of country fixed-effects and region fixed-effects reflect deviations from the "grand mean" rather than deviations from the reference category. The modified coefficients sum up to zero over all categories. Robust standard errors clustered by country.

This table displays one regression of Happiness. 
Table 1.C. Derivation of Parameters Based on the Estimation of Equation (1)

Decomposition of the National Happiness Gap due to Circumstances and Mentality

\begin{tabular}{lccc}
\hline Happiness & Natives fixed effects & Circumstances & Mentality \\
& $\boldsymbol{\gamma}_{\mathbf{j}}$ & $\boldsymbol{\gamma}_{\mathbf{j}}+\boldsymbol{\mu}_{\boldsymbol{j}}$ & $-\boldsymbol{\mu}_{\mathbf{j}}$ \\
\hline & & & \\
Belgium & 0.185 & 0.112 & 0.073 \\
Switzerland & 0.259 & 0.098 & 0.161 \\
Germany & -0.321 & -0.284 & -0.037 \\
France & -0.312 & -0.068 & -0.244 \\
UK & -0.217 & -0.242 & 0.025 \\
Netherlands & 0.130 & 0.177 & -0.047 \\
Sweden & 0.275 & 0.206 & 0.069 \\
\hline
\end{tabular}

Coefficients derived from the estimate of equation (2) presented in Table A1.

Note: These are measures of the gap between national happiness and the European average that is due to each factor. Consequently. all columns sum to zero. For example, the happiness gap between French natives and European natives is of -0.312 (column 3): it is largely attributable to Mentality $(-0.244)$ and only weakly to Circumstances (0.068).

Table 1.D. Derivation of Parameters Based on the Estimation of Equation (1)

European immigrants only

\begin{tabular}{lccc}
\hline Happiness & Natives fixed effects & Circumstances & Mentality \\
& $\boldsymbol{\gamma}_{\mathrm{j}}$ & $\boldsymbol{\gamma}_{\mathrm{j}}+\boldsymbol{\mu}_{\mathrm{j}}$ & $\boldsymbol{-} \boldsymbol{\mu}_{\mathrm{j}}$ \\
\hline Belgium & 0,187 & 0,18261 & 0,00439 \\
Switzerland & 0,258 & 0,1587 & 0,0993 \\
Germany & $-0,322$ & $-0,2694$ & $-0,0526$ \\
France & $-0,311$ & $-0,108$ & $-0,203$ \\
UK & $-0,215$ & $-0,3108$ & 0,0958 \\
Netherlands & 0,127 & 0,1034 & 0,0236 \\
Sweden & 0,274 & 0,2411 & 0,0329 \\
\hline
\end{tabular}


Table 2.A Simulating the Happiness of Natives with the Parameters of Immigrants: all Immigrants

\begin{tabular}{lccc}
\hline Happiness & $\begin{array}{c}(\mathbf{1}) \\
\text { Actual Happiness of } \\
\text { Natives }\end{array}$ & $\begin{array}{c}\mathbf{( 2 )} \\
\text { Happiness of Natives } \\
\text { with Parameters of } \\
\text { Immigrants }\end{array}$ & $\begin{array}{c}\mathbf{( 3 )} \\
\text { Happiness Gap of } \\
\text { Natives due to } \\
\text { Parameters (1-3) }\end{array}$ \\
\hline Belgium & 7.77 & 7.71 & 0.06 \\
Switzerland & 8.07 & 7.85 & 0.22 \\
Germany & 7.22 & 7.30 & -0.08 \\
France & 7.19 & 7.30 & -0.11 \\
UK & 7.38 & 7.26 & 0.12 \\
Netherlands & 7.75 & 7.75 & 0.00 \\
Sweden & 7.89 & 7.76 & 0.13 \\
\hline
\end{tabular}

Values calculated on the regression sample.

Table 2.B Simulating the Happiness of Natives with the Parameters of Immigrants: only EU Immigrants

\begin{tabular}{lccc}
\hline Happiness & $\begin{array}{c}(\mathbf{1}) \\
\text { Actual Happiness of } \\
\text { Natives }\end{array}$ & $\begin{array}{c}\text { (2) } \\
\text { Happiness of Natives } \\
\text { with Parameters of } \\
\text { Immigrants }\end{array}$ & $\begin{array}{c}\text { (3) } \\
\text { Gap due to } \\
\text { Parameters }\end{array}$ \\
Belgium & & & -0.04 \\
Switzerland & 7.77 & 7.81 & 0.23 \\
Germany & 8.07 & 7.84 & -0.13 \\
France & 7.22 & 7.35 & -0.15 \\
UK & 7.19 & 7.35 & 0.16 \\
Netherlands & 7.38 & 7.21 & 0.06 \\
Sweden & 7.75 & 7.69 & 0.21 \\
\hline
\end{tabular}

Values calculated on the regression sample.

Sample restricted to immigrants from one of the $28 \mathrm{EU}$ countries. 
Table 3. OLS Estimates of Happiness of Europeans living in Another European Country

\begin{tabular}{|c|c|c|c|}
\hline & (1) & (2) & (3) \\
\hline Happiness & All migrants & 1st generation & $2^{\text {nd }} \& 1.5 \mathrm{~g}$ \\
\hline \multicolumn{4}{|c|}{ Country of Origin } \\
\hline \multirow[t]{2}{*}{ Belgium } & $-0.206 * * *$ & $-0.186^{* * *}$ & $-0.205^{* * *}$ \\
\hline & $(0.00967)$ & $(0.0199)$ & $(0.0122)$ \\
\hline \multirow[t]{2}{*}{ Switzerland } & $0.401 * * *$ & $0.439 * * *$ & $0.375^{* * *}$ \\
\hline & $(0.00522)$ & $(0.0275)$ & $(0.0137)$ \\
\hline \multirow[t]{2}{*}{ Germany } & -0.00390 & $0.0437 * * *$ & $-0.0227 * * *$ \\
\hline & $(0.00805)$ & $(0.0112)$ & $(0.00590)$ \\
\hline \multirow[t]{2}{*}{ France } & $-0.104 * * *$ & -0.0313 & $-0.198 * * *$ \\
\hline & $(0.00451)$ & $(0.0166)$ & $(0.00696)$ \\
\hline \multirow[t]{2}{*}{ Great-Britain } & $-0.232 * * *$ & $-0.244 * * *$ & $-0.263 * * *$ \\
\hline & $(0.0134)$ & $(0.0291)$ & $(0.0246)$ \\
\hline \multirow[t]{2}{*}{ Netherlands } & $0.0296 * *$ & -0.0322 & $0.0796 * * *$ \\
\hline & $(0.0108)$ & $(0.0249)$ & $(0.0122)$ \\
\hline \multirow[t]{2}{*}{ Sweden } & $0.115^{* * *}$ & 0.0109 & $0.233^{* * *}$ \\
\hline & $(0.00771)$ & $(0.0168)$ & $(0.0102)$ \\
\hline \multirow[t]{2}{*}{ Constant } & $5.661 * * *$ & $5.661 * * *$ & $5.912 * * *$ \\
\hline & $(0.335)$ & $(0.502)$ & $(0.601)$ \\
\hline Observations & 3.069 & 1.659 & 1.410 \\
\hline R-squared & 0.074 & 0.069 & 0.086 \\
\hline
\end{tabular}

Sample: Migrants from the $7 \mathrm{EU}$ countries mentioned in the table living in any of the 28 European countries of the ESS.

Other controls: age. age square. gender. log household income. marital status. employment status. year fixed-effects. country of residence. Cluster (country of origin).

No information about country of origin of immigrants in ESS wave 1.

The coefficients of country fixed-effects reflect deviations from the "grand mean". not the deviations from a reference category. 
Table 4. Happiness and Life Satisfaction of Migrants; the role of time. OLS Estimates

\begin{tabular}{|c|c|c|}
\hline Happiness & $(1)$ & $(2)$ \\
\hline Belgium & $\begin{array}{l}0.212^{* * *} \\
(0.0188)\end{array}$ & $\begin{array}{l}0.316^{* * *} \\
(0.0148)\end{array}$ \\
\hline Switzerland & $\begin{array}{l}0.0933 * * * \\
(0.0172)\end{array}$ & $\begin{array}{l}0.0492 * * \\
(0.0171)\end{array}$ \\
\hline Germany & $\begin{array}{l}-0.597 * * * \\
(0.0189)\end{array}$ & $\begin{array}{l}-0.595^{* * *} \\
(0.0267)\end{array}$ \\
\hline France & $\begin{array}{l}0.242 * * * \\
(0.0190)\end{array}$ & $\begin{array}{l}0.361 * * * \\
(0.0161)\end{array}$ \\
\hline Great-Britain & $\begin{array}{l}-0.445^{* * *} \\
(0.0341)\end{array}$ & $\begin{array}{l}-0.440 * * * \\
(0.0260)\end{array}$ \\
\hline Netherlands & $\begin{array}{l}0.360^{* * *} \\
(0.0184)\end{array}$ & $\begin{array}{l}0.287 * * * \\
(0.0168)\end{array}$ \\
\hline Sweden & $\begin{array}{l}0.134 * * * \\
(0.0148)\end{array}$ & $\begin{array}{l}0.0228 \\
(0.0163)\end{array}$ \\
\hline Came to this country more than 20 years ago & & $\begin{array}{l}-0.304^{* * *} \\
(0.0575)\end{array}$ \\
\hline Came to this country more than 10 years ago & $\begin{array}{c}-0.180^{* *} \\
(0.0549)\end{array}$ & \\
\hline Over 10 years in Belgium & $\begin{array}{l}-0.00827 \\
(0.00804)\end{array}$ & \\
\hline Over 10 years in Switzerland & $\begin{array}{l}0.00244 \\
(0.00452)\end{array}$ & \\
\hline Over 10 years in Germany & $\begin{array}{l}0.481 \text { *** } \\
(0.0297)\end{array}$ & \\
\hline Over 10 years in France & $\begin{array}{l}-\mathbf{0 . 3 7 1} \text { *** } \\
(0.0262)\end{array}$ & \\
\hline Over 10 years in Great-Britain & $\begin{array}{l}0.0881 \text { *** } \\
(0.0209)\end{array}$ & \\
\hline Over 10 years in Netherlands & $\begin{array}{l}-0.240^{* * *} \\
(0.0255)\end{array}$ & \\
\hline Over 10 years in Sweden & $\begin{array}{l}0.0486^{*} \\
(0.0237)\end{array}$ & \\
\hline Over 20 years in Belgium & & $\begin{array}{l}-0.225 * * * \\
(0.0235)\end{array}$ \\
\hline Over 20 years in Switzerland & & $\begin{array}{l}0.0806^{* * *} \\
(0.0112)\end{array}$ \\
\hline Over 20 years in Germany & & $\begin{array}{l}0.712 * * * \\
(0.0250)\end{array}$ \\
\hline Over 20 years in France & & $\begin{array}{l}-0.601 * * * \\
(0.0152)\end{array}$ \\
\hline Over 20 years in Great-Britain & & $\begin{array}{l}0.113 * * * \\
(0.0212)\end{array}$ \\
\hline Over 20 years in Netherlands & & $\begin{array}{l}-0.287^{* * *} \\
(0.0285)\end{array}$ \\
\hline Over 20 years in Sweden & & $\begin{array}{l}0.208^{* * *} \\
(0.0189)\end{array}$ \\
\hline Constant & $\begin{array}{l}6.159 * * * \\
(0.358)\end{array}$ & $\begin{array}{l}6.407 * * * \\
(0.332)\end{array}$ \\
\hline Observations & 1,915 & 1,915 \\
\hline R-squared & 0.070 & 0.075 \\
\hline
\end{tabular}


Sample: Migrants from the 28 European countries living in any of the 7 ESS countries mentioned in the Table.

Other controls: age, age square, gender, log household income, marital status, employment status, year fixed-effects. Cluster (country).

The coefficients of country fixed-effects reflect deviations from the "grand mean", not the deviations from a reference category. 
Table 5. Satisfaction viz. Different Domains: French Natives versus First and Second Generation Immigrants. OLS Estimates.

\begin{tabular}{|c|c|c|c|c|c|c|c|c|c|c|}
\hline & (1) & (2) & (3) & (4) & (5) & (6) & (7) & (8) & (9) & (10) \\
\hline & $\begin{array}{c}\text { Depressiveness } \\
\text { Index } \\
(0-59)\end{array}$ & $\begin{array}{c}\text { Life } \\
\text { Satisfaction (0- } \\
10)\end{array}$ & $\begin{array}{c}\text { Satisfaction } \\
\text { with Economy } \\
(0-10)\end{array}$ & $\begin{array}{c}\text { Satisfaction } \\
\text { with national } \\
\text { government } \\
(0-10) \\
\end{array}$ & $\begin{array}{c}\text { Satisfaction } \\
\text { with democracy } \\
(0-10)\end{array}$ & $\begin{array}{c}\text { Satisfaction } \\
\text { with education } \\
\text { system } \\
(0-10) \\
\end{array}$ & $\begin{array}{c}\text { Satisfaction } \\
\text { with Health } \\
\text { system } \\
(0-10) \\
\end{array}$ & $\begin{array}{c}\text { Living } \\
\text { comfortably } \\
\text { on present } \\
\text { income (1-4) } \\
\end{array}$ & $\begin{array}{l}\text { Hard to be } \\
\text { bopeful about the } \\
\text { future of the } \\
\text { world (1-5) }\end{array}$ & $\begin{array}{c}\text { For most people } \\
\text { in country life is } \\
\text { getting worse } \\
(1-5)\end{array}$ \\
\hline \multicolumn{11}{|l|}{ All immigrants } \\
\hline France & $\begin{array}{l}1.347 * * * \\
(0.0319)\end{array}$ & $\begin{array}{c}-0.869 * * * \\
(0.0130)\end{array}$ & $\begin{array}{c}-1.347 * * * \\
(0.0184)\end{array}$ & $\begin{array}{c}-0.610^{* * *} \\
(0.0230)\end{array}$ & $\begin{array}{c}-0.954 * * * \\
(0.0127)\end{array}$ & $\begin{array}{c}-0.649 * * * \\
(0.0108)\end{array}$ & $\begin{array}{c}0.0410^{* *} \\
(0.0165)\end{array}$ & $\begin{array}{l}-0.0247 * * \\
(0.00714)\end{array}$ & $\begin{array}{l}0.543 * * * \\
(0.00223)\end{array}$ & $\begin{array}{l}0.702 * * * \\
(0.00393)\end{array}$ \\
\hline $\begin{array}{l}1 \text { st generation immigrants in } \\
\text { France }\end{array}$ & $\begin{array}{l}-0.354 \\
(0.220)\end{array}$ & $\begin{array}{c}0.0735^{* *} \\
(0.0212)\end{array}$ & $\begin{array}{l}0.0898^{*} \\
(0.0376)\end{array}$ & $\begin{array}{l}-0.146^{* *} \\
(0.0568)\end{array}$ & $\begin{array}{l}0.125^{* * *} \\
(0.0209)\end{array}$ & $\begin{array}{l}0.190^{* * *} \\
(0.0233)\end{array}$ & $\begin{array}{l}0.207 * * * \\
(0.0269)\end{array}$ & $\begin{array}{l}0.144 * * * \\
(0.0105)\end{array}$ & $\begin{array}{c}-0.0961 * * \\
(0.0373)\end{array}$ & $\begin{array}{r}-0.00196 \\
(0.0431)\end{array}$ \\
\hline $\begin{array}{l}2^{\text {nd }} \text { generation immigrants in } \\
\text { France }\end{array}$ & $\begin{array}{l}0.0831 \\
(0.213)\end{array}$ & $\begin{array}{c}0.255^{* * *} \\
(0.0220)\end{array}$ & $\begin{array}{l}0.258 * * * \\
(0.0370)\end{array}$ & $\begin{array}{c}-0.313^{* * *} \\
(0.0507)\end{array}$ & $\begin{array}{c}0.0153 \\
(0.0175)\end{array}$ & $\begin{array}{l}0.185^{* * *} \\
(0.0232)\end{array}$ & $\begin{array}{c}0.0346 \\
(0.0463)\end{array}$ & $\begin{array}{c}0.127 * * * \\
(0.0105)\end{array}$ & $\begin{array}{l}-0.0389 \\
(0.0308)\end{array}$ & $\begin{array}{c}-0.283^{* * *} \\
(0.0390)\end{array}$ \\
\hline Constant & $\begin{array}{c}15.89 * * * \\
(0.969)\end{array}$ & $\begin{array}{c}5.651 * * * \\
(0.289)\end{array}$ & $\begin{array}{c}2.710^{* * *} \\
(0.665)\end{array}$ & $\begin{array}{c}3.549 * * * \\
(0.313)\end{array}$ & $\begin{array}{c}3.581 * * * \\
(0.237)\end{array}$ & $\begin{array}{l}7.586^{* * *} \\
(0.331)\end{array}$ & $\begin{array}{c}6.613 * * * \\
(0.448)\end{array}$ & $\begin{array}{l}0.371^{*} \\
(0.181)\end{array}$ & $\begin{array}{c}3.793 * * * \\
(0.201)\end{array}$ & $\begin{array}{c}4.327 * * * \\
(0.316)\end{array}$ \\
\hline Observations & 8.369 & 44,422 & 43.998 & 43.620 & 43.740 & 43.264 & 44.229 & 42.425 & 8.988 & 8.378 \\
\hline R-squared & 0.110 & 0.149 & 0.182 & 0.113 & 0.124 & 0.121 & 0.147 & 0.282 & 0.112 & 0.194 \\
\hline \multicolumn{11}{|l|}{ Only European Immigrants } \\
\hline $\begin{array}{l}\text { 1st generation immigrants in } \\
\text { France }\end{array}$ & $\begin{array}{l}-0.0549 \\
(0.0722)\end{array}$ & $\begin{array}{c}0.0379 * * \\
(0.0150)\end{array}$ & $\begin{array}{l}0.0918^{*} \\
(0.0463)\end{array}$ & $\begin{array}{l}0.0251 \\
(0.0245)\end{array}$ & $\begin{array}{c}0.0111 \\
(0.0125)\end{array}$ & $\begin{array}{l}0.553 * * * \\
(0.00883)\end{array}$ & $\begin{array}{c}0.269 * * * \\
(0.00841)\end{array}$ & $\begin{array}{l}0.110^{* * *} \\
(0.00518)\end{array}$ & $\begin{array}{l}-0.166^{* * *} \\
(0.00664)\end{array}$ & $\begin{array}{c}0.00356 \\
(0.00879)\end{array}$ \\
\hline $\begin{array}{l}2^{\text {nd }} \text { generation immigrants in } \\
\text { France }\end{array}$ & $\begin{array}{r}0.439 * * * \\
(0.0873)\end{array}$ & $\begin{array}{c}0.0994 * * * \\
(0.0147)\end{array}$ & $\begin{array}{c}-0.0587 * * * \\
(0.0111)\end{array}$ & $\begin{array}{c}-0.149 * * * \\
(0.0182)\end{array}$ & $\begin{array}{c}-0.368 * * * \\
(0.0160)\end{array}$ & $\begin{array}{c}-0.0966 * * * \\
(0.00670)\end{array}$ & $\begin{array}{c}-0.277^{* * *} \\
(0.0191)\end{array}$ & $\begin{array}{c}0.0213^{*} \\
(0.00890)\end{array}$ & $\begin{array}{l}0.369 * * * \\
(0.00672)\end{array}$ & $\begin{array}{l}0.146^{* * *} \\
(0.00880)\end{array}$ \\
\hline Constant & $\begin{array}{c}15.73 * * * \\
(1.026)\end{array}$ & $\begin{array}{c}5.539 * * * \\
(0.341)\end{array}$ & $\begin{array}{c}3.014^{* * *} \\
(0.666)\end{array}$ & $\begin{array}{c}3.666 * * * \\
(0.342)\end{array}$ & $\begin{array}{c}3.526 * * * \\
(0.243)\end{array}$ & $\begin{array}{c}7.183^{* * *} \\
(0.329)\end{array}$ & $\begin{array}{c}6.031^{* * *} \\
(0.418)\end{array}$ & $\begin{array}{c}0.662^{* * *} \\
(0.160)\end{array}$ & $\begin{array}{c}3.936^{* * *} \\
(0.164)\end{array}$ & $\begin{array}{c}4.299 * * * \\
(0.245)\end{array}$ \\
\hline Observations & 7.738 & 40,91 & 40.544 & 40.250 & 40.337 & 39.886 & 40.744 & 39.054 & 8.292 & 7.733 \\
\hline R-squared & 0.108 & 0.151 & 0.189 & 0.113 & 0.125 & 0.123 & 0.148 & 0.269 & 0.115 & 0.202 \\
\hline
\end{tabular}

Other controls: age, age square, marital status, male, log household income, region of origin (upper panel). migration status, employment status, year fixed-effects, country fixed effects and interactions for each of the 7 other countries of the sample. See the entire regressions in Tables E1.A and E1.B in the Electronic Appendix.

Variables recoded in ascending order when necessary.

The coefficients of country fixed-effects reflect deviations from the "grand mean" rather than deviations from the reference category.

Robust standard errors clustered by country. 
Table 6.A Happiness and Usual Language in Belgium

OLS Estimates

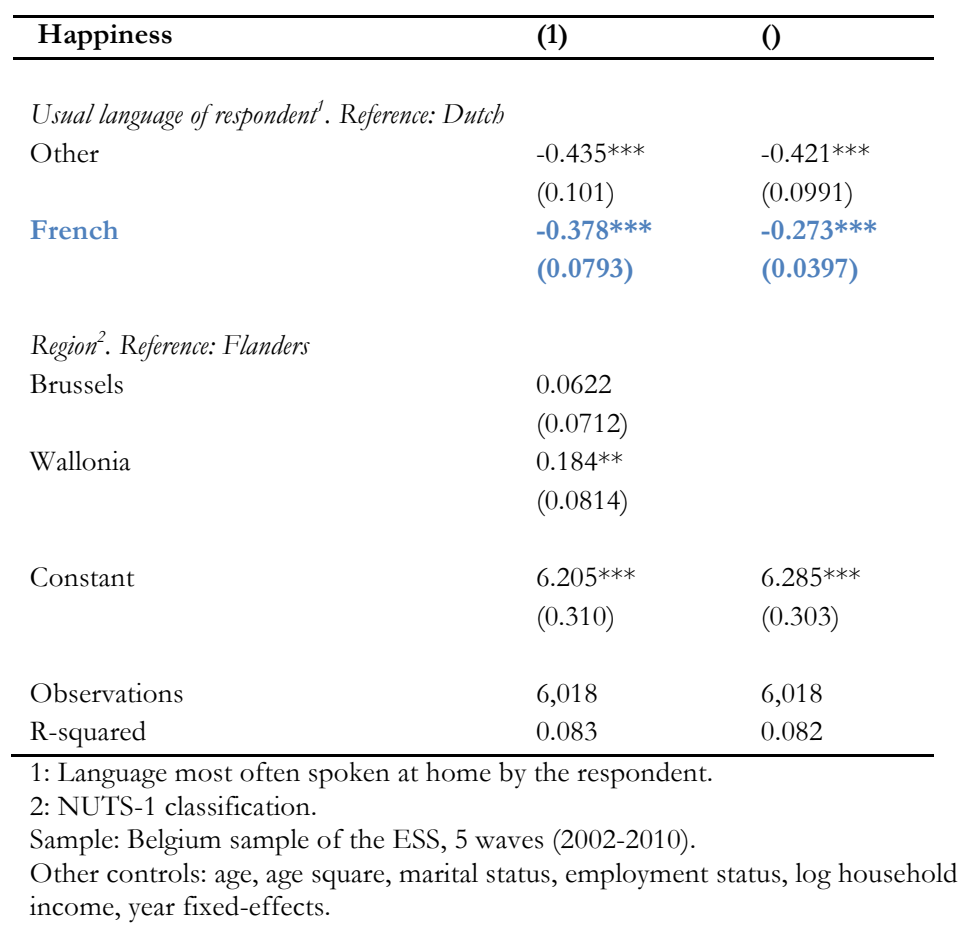


Table 6.B Happiness and Usual Language in Switzerland OLS Estimates of Happiness

\begin{tabular}{lcc}
\hline Happiness & $\mathbf{( 1 )}$ & $\mathbf{( 2 )}$ \\
\hline Language sopken at home ${ }^{1}$. Reference: Italian & & \\
Other & $0.217^{*}$ & $0.201^{* *}$ \\
& $(0.117)$ & $(0.0954)$ \\
German & $0.441^{* * *}$ & $0.436^{* * *}$ \\
& $(0.114)$ & $(0.0857)$ \\
French & $0.312^{* *}$ & $0.416^{* * *}$ \\
& $(0.133)$ & $(0.0905)$ \\
Regional language ${ }^{2}$. Reference: Italian & & \\
German & -0.0303 & \\
& $(0.134)$ & \\
French & 0.0946 & \\
& $(0.149)$ & \\
Constant & & $6.044^{* * *}$ \\
& $5.988^{* * *}$ & $(0.331)$ \\
R-squared & $(0.377)$ & 5,870 \\
\hline
\end{tabular}

1: Language most often spoken at home by the respondent.

2: Dominant language in the region.

Sample: Swiss sample of the ESS, 5 waves (2002-2010).

Other controls: age, age square, marital status, employment status, log household income, year fixed-effects. 
Table 6.C Happiness and Language in Canada

OLS Estimates

\begin{tabular}{|c|c|c|}
\hline Happiness & (1) & (2) \\
\hline \multicolumn{3}{|c|}{ Language of interview (omitted: English) } \\
\hline French & $\begin{array}{l}0.0433 * \\
(0.0231)\end{array}$ & \\
\hline Other & $\begin{array}{c}-0.000434 \\
(0.336)\end{array}$ & \\
\hline \multicolumn{3}{|c|}{ Language spoken at home (omitted: English) } \\
\hline French & & $\begin{array}{c}0.0525 * * \\
(0.0230)\end{array}$ \\
\hline Other & & $\begin{array}{c}-0.113^{* *} \\
(0.0488)\end{array}$ \\
\hline Age & $\begin{array}{c}-0.0140 * * * \\
(0.00355)\end{array}$ & $\begin{array}{c}-0.0141 * * * \\
(0.00355)\end{array}$ \\
\hline Age2 & $\begin{array}{c}0.000132 * * * \\
(3.68 \mathrm{e}-05)\end{array}$ & $\begin{array}{c}0.000130 * * * \\
(3.67 \mathrm{e}-05)\end{array}$ \\
\hline Male & $\begin{array}{c}-0.0623^{* * *} \\
(0.0213)\end{array}$ & \\
\hline \multicolumn{3}{|c|}{ Marital status (omitted : married) } \\
\hline Living together & $\begin{array}{c}-0.114 * * * \\
(0.0344)\end{array}$ & $\begin{array}{c}-0.120^{* * *} \\
(0.0343)\end{array}$ \\
\hline Divorced & $\begin{array}{c}-0.170^{* * *} \\
(0.0422)\end{array}$ & $\begin{array}{c}-0.169 * * * \\
(0.0420)\end{array}$ \\
\hline Separated & $\begin{array}{c}-0.294 * * * \\
(0.0513)\end{array}$ & $\begin{array}{c}-0.283 * * * \\
(0.0507)\end{array}$ \\
\hline Widow & $\begin{array}{c}-0.208^{* * *} \\
(0.0426)\end{array}$ & $\begin{array}{c}-0.191 * * * \\
(0.0418)\end{array}$ \\
\hline Single & $\begin{array}{c}-0.265^{* * *} \\
(0.0315)\end{array}$ & $\begin{array}{c}-0.271 * * * \\
(0.0314)\end{array}$ \\
\hline Income scale & $\begin{array}{c}0.0139 * * * \\
(0.00455)\end{array}$ & $\begin{array}{c}0.0131 * * * \\
(0.00451)\end{array}$ \\
\hline Constant & $\begin{array}{c}3.716^{* * *} \\
(0.142)\end{array}$ & $\begin{array}{c}3.750 * * * \\
(0.144)\end{array}$ \\
\hline Observations & 3.439 & 3.461 \\
\hline R-squared & 0.061 & 0.060 \\
\hline
\end{tabular}

Other controls: year fixed-effects, ethnic group, employment status, education.

Source: World Values Survey, years: 2000 and 2006. 
Figure 4.A Mean Frequency of Negative Emotions by Country

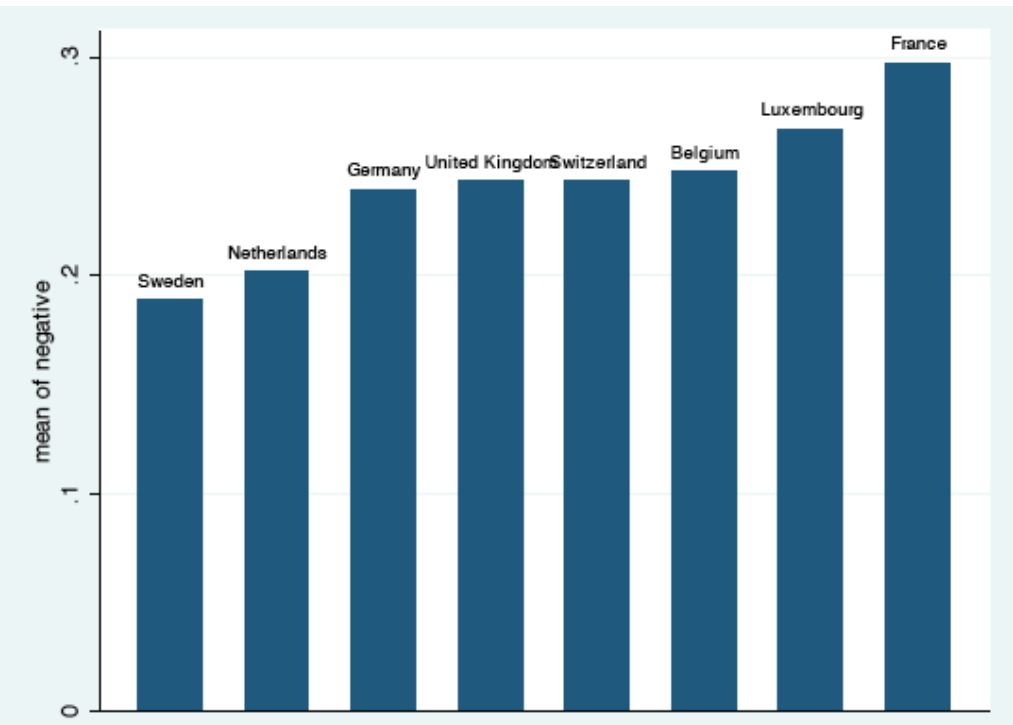

Source: Gallup World Poll (2007-2009). Negative emotions yesterday: worry, sadness, anger, stress. Yes/No answers. Country averages.

Figure 4.B Mean Frequency of Positive Emotions by Country

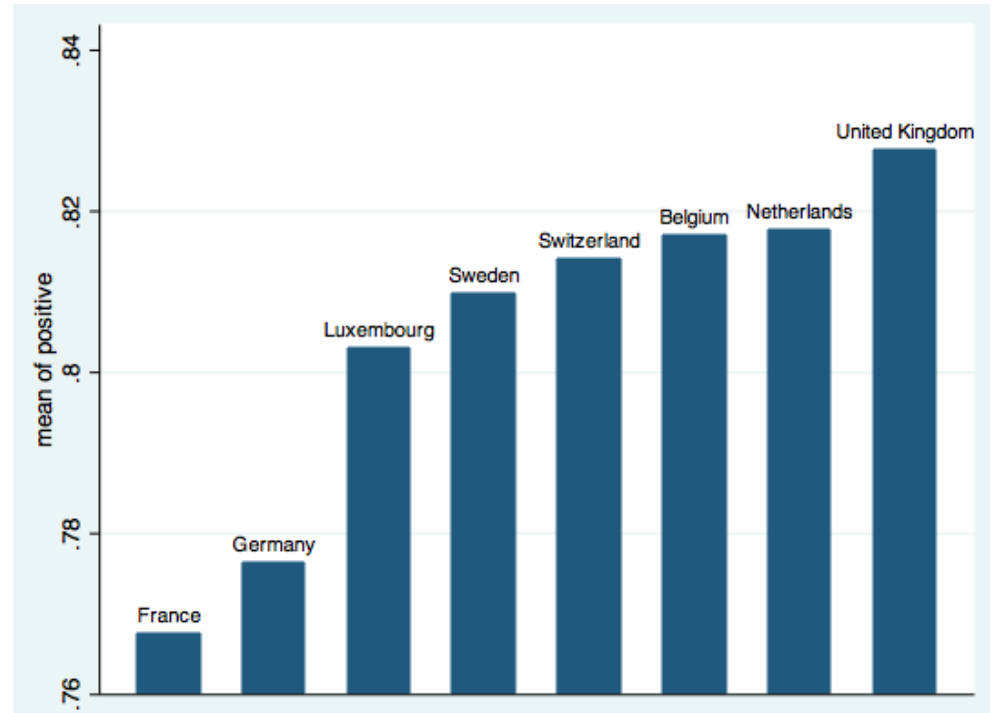

Source: Gallup World Poll (2007-2009). Positive emotions yesterday: enjoyment, smile, happiness. Yes/No answers. Country averages. 


\section{Appendix}

Descriptive Statistics of the Regression Sample (ESS, waves 1-5, 20022010)

Table A1. Composition of Countries by Migration Status

\begin{tabular}{lccccc}
\hline Country & Natives & $\begin{array}{c}\text { First } \\
\text { generation } \\
\text { immigrants }\end{array}$ & $\begin{array}{c}\text { Second } \\
\text { generation } \\
\text { immigrants }\end{array}$ & $\begin{array}{c}1.5 \\
\text { generation } \\
\text { immigrants }\end{array}$ & Total \\
\hline Belgium & 4905 & 501 & 213 & 372 & 5991 \\
Switzerland & 3857 & 1093 & 243 & 590 & 5783 \\
Germany & 7485 & 717 & 207 & 535 & 8944 \\
France & 5091 & 489 & 250 & 488 & 6318 \\
Great-Britain & 5849 & 607 & 176 & 383 & 7015 \\
Netherlands & 5741 & 553 & 111 & 321 & 6726 \\
Sweden & 5491 & 685 & 152 & 480 & 6808 \\
& & & & 3169 & 47585 \\
Total & 38419 & 4645 & 1352 & They are
\end{tabular}
generally not included in the regressions.

Table A2. Composition of Countries by Migration Status: Only EU immigrants

\begin{tabular}{lccccc}
\hline Country & Natives & $\begin{array}{c}\text { First generation } \\
\text { immigrants }\end{array}$ & $\begin{array}{c}\text { Second } \\
\text { generation } \\
\text { immigrants }\end{array}$ & $\begin{array}{c}1.5 \\
\text { generation } \\
\text { immigrants }\end{array}$ & Total \\
\hline Belgium & 4860 & 261 & 125 & 312 & 5558 \\
Switzerland & 3836 & 732 & 227 & 541 & 5336 \\
Germany & 7457 & 169 & 139 & 475 & 8240 \\
France & 5052 & 148 & 132 & 285 & 5617 \\
Great-Britain & 5792 & 146 & 62 & 238 & 6238 \\
Netherlands & 5702 & 133 & 15 & 178 & 6028 \\
Sweden & 5470 & 328 & 124 & 434 & 6356 \\
Total & 38169 & 1917 & 824 & 2463 & 43373 \\
\hline
\end{tabular}

1.5 generation refers to individuals born to one foreign-born parent and one native parent. They are generally not included in the regressions. 
Table A3. Region of Origin of Immigrants in Europe (only $1^{\text {st }}$ and $2^{\text {nd }}$ generation)

\begin{tabular}{lcccccccc}
\hline Destination $\rightarrow$ & Belgium & Switzerland & Germany & France & Great-Britain & Netherlands & Sweden & Total \\
\hline Origin $\downarrow$ & & & & & & & & \\
Europe & 722 & 1580 & 908 & 575 & 478 & 356 & 969 & 5588 \\
Africa & 215 & 75 & 29 & 544 & 170 & 120 & 43 & 1196 \\
Asia-Australasia & 123 & 163 & 480 & 67 & 383 & 345 & 233 & 1794 \\
North America & 11 & 33 & 28 & 9 & 59 & 11 & 17 & 168 \\
Latin America \& Carribean & 15 & 75 & 14 & 32 & 76 & 153 & 55 & 420 \\
Total & 1086 & 1926 & 1459 & 1227 & 1166 & 985 & 1317 & 9166 \\
\hline
\end{tabular}

Table A4. Region of Origin of European Immigrants in Europe (only $1^{\text {st }}$ and $2^{\text {nd }}$ generation)

\begin{tabular}{|c|c|c|c|c|c|c|c|c|}
\hline & Belgium & Switzerland & Germany & France & Great-Britain & Netherlands & Sweden & Total \\
\hline AT & & 48 & 13 & 2 & & 1 & 5 & 69 \\
\hline $\mathrm{BE}$ & 125 & 6 & & 8 & 5 & 24 & & 168 \\
\hline BG & 1 & 3 & 2 & & 2 & & 4 & 12 \\
\hline $\mathrm{CH}$ & & 228 & 2 & 5 & 2 & 1 & 6 & 244 \\
\hline $\mathrm{CZ}$ & & 8 & 16 & & 5 & 1 & 4 & 34 \\
\hline DE & 12 & 206 & 139 & 17 & 21 & 37 & 28 & 460 \\
\hline DK & & 2 & 2 & & & & 24 & 28 \\
\hline EE & & & 1 & & & & 5 & 6 \\
\hline ES & 12 & 42 & 9 & 19 & 9 & 6 & 4 & 101 \\
\hline FI & & 4 & 1 & 1 & 2 & & 152 & 160 \\
\hline FR & 82 & 97 & 8 & 132 & 13 & 9 & 3 & 344 \\
\hline GB & 5 & 28 & 9 & 7 & 62 & 19 & 12 & 142 \\
\hline GR & 6 & 3 & 8 & 3 & 1 & 4 & 4 & 29 \\
\hline HR & & 40 & 7 & 2 & 2 & 2 & 7 & 60 \\
\hline $\mathrm{HU}$ & & 7 & 7 & 1 & 1 & 1 & 10 & 27 \\
\hline IE & & 3 & 2 & 1 & 45 & 3 & 2 & 56 \\
\hline IT & 57 & 119 & 27 & 25 & 12 & 8 & 5 & 253 \\
\hline LT & & & 2 & & 6 & 2 & 1 & 11 \\
\hline $\mathrm{LU}$ & & 1 & 1 & 2 & & & & 4 \\
\hline LV & 1 & & 2 & & 1 & & 2 & 6 \\
\hline MT & & & & & 1 & & & 1 \\
\hline NL & 61 & 20 & 7 & & 3 & 15 & 8 & 114 \\
\hline $\mathrm{NO}$ & 1 & 1 & 1 & & & & 32 & 35 \\
\hline PT & 8 & 69 & 5 & 51 & 10 & 5 & 1 & 149 \\
\hline RO & 12 & 6 & 33 & 1 & 2 & 6 & 7 & 67 \\
\hline SE & 2 & 7 & 1 & 1 & 2 & 2 & 124 & 139 \\
\hline SI & & 4 & & & & 1 & 1 & 6 \\
\hline SK & 1 & 7 & 3 & 2 & 1 & 1 & 1 & 16 \\
\hline Total & 386 & 959 & 308 & 280 & 208 & 148 & 452 & 2741 \\
\hline
\end{tabular}


Table A5. Descriptive Statistics of the Variables of Interest in the Regression Sample

\begin{tabular}{|c|c|c|c|c|c|c|}
\hline & Variable & Obs & Mean & std dev. & Min & $\operatorname{Max}$ \\
\hline Log household income & $\operatorname{loginc}$ & 47585 & 7,85 & 0,73 & 4,62 & 9,62 \\
\hline Age & age & 47585 & 42,17 & 13,16 & 16 & 65 \\
\hline Male & male & 47585 & 0,49 & 0,50 & 0 & 1 \\
\hline Single & single & 47585 & 0,30 & 0,46 & 0 & 1 \\
\hline married & married & 47585 & 0,57 & 0,50 & 0 & 1 \\
\hline divorced & divorced & 47585 & 0,11 & 0,31 & 0 & 1 \\
\hline widowed & widowed & 47585 & 0,02 & 0,14 & 0 & 1 \\
\hline How happy are you? & happy & 47585 & 7,60 & 1,67 & 0 & 10 \\
\hline Life Satisfaction & stflife & 47546 & 7.27 & 2.01 & 0 & 10 \\
\hline How satisfied with present state of economy in country & stfeco & 47098 & 4,76 & 2,25 & 0 & 10 \\
\hline How satisfied with the national government & stfgov & 46692 & 4,45 & 2,22 & 0 & 10 \\
\hline How satisfied with the way democracy works in country & stfdem & 46837 & 5,58 & 2,31 & 0 & 10 \\
\hline Satisfied with the state of education in country nowadays & stfedu & 46331 & 5,50 & 2,16 & 0 & 10 \\
\hline State of health services in country nowadays & stfhlth & 47339 & 5,75 & 2,25 & 0 & 10 \\
\hline Feeling about household's income nowadays & hincfel2 & 45368 & 3,25 & 0,77 & 1 & 4 \\
\hline Depressiveness score ${ }^{12}$ & depressed & 9001 & 2,36 & 6,65 & -13 & 39 \\
\hline Difficult to have hope for the future of the world ${ }^{2}$ & hope_world & 9640 & 3,22 & 1,02 & 1 & 5 \\
\hline For most people in country life is getting worse ${ }^{2}$ & life_worse & 9005 & 3,41 & 1,01 & 1 & 5 \\
\hline
\end{tabular}

${ }^{1}$ Average score of depressiveness symptoms. How often last week: Felt depressed; Felt everything did as effort; Sleep was restless, Felt lonely, Felt sad, Could not get going, Felt anxious, Felt tired, Felt bored, Felt rested when woke up in morning, Seldom time to do things I really enjoy, Little chance to show how capable I am, Feel accomplishment from what I do, In general feel very positive about myself, Always optimistic about my future, At times feel as if I am a failure.

2 Only available in wave 3 (2006).

When relevant, variables have been recoded in ascending order.

Weighted statistics. 
Table A.6. World Values Survey, Canadian sample $(2000,2006)$

\begin{tabular}{|c|c|c|c|c|c|}
\hline Variable & Observations & Mean & Std. Dev. & Min & Max \\
\hline Happy & 3461 & 3.41 & 0.59 & 1.00 & 4.00 \\
\hline Age & 3461 & 47.20 & 17.32 & 16.00 & 95.00 \\
\hline Male & 3460 & $42 \%$ & & & \\
\hline \multicolumn{6}{|c|}{ Interview language } \\
\hline English & 3440 & $74 \%$ & & & \\
\hline French & 3440 & $26 \%$ & & & \\
\hline Other & 3440 & $0 \%$ & & & \\
\hline \multicolumn{6}{|c|}{ Home language } \\
\hline Other & 3461 & $5 \%$ & & & \\
\hline English & 3461 & $68 \%$ & & & \\
\hline French & 3461 & $26 \%$ & & & \\
\hline
\end{tabular}

Table A7 Country Mean Frequency of Affect

\begin{tabular}{lccccccc}
\hline & Smile & Enjoy & Worry & Sad & Stress & Angry & Happy \\
\hline Belgium & 0,83 & 0,81 & 0,32 & 0,18 & 0,33 & 0,20 & 0,81 \\
France & 0,78 & 0,76 & 0,33 & 0,19 & 0,36 & 0,33 & 0,76 \\
Germany & 0,76 & 0,74 & 0,28 & 0,19 & 0,38 & 0,14 & 0,87 \\
Netherlands & 0,80 & 0,84 & 0,35 & 0,16 & 0,20 & 0,09 & 0,82 \\
Sweden & 0,79 & 0,87 & 0,22 & 0,14 & 0,28 & 0,14 & 0,76 \\
Switzerland & 0,76 & 0,83 & 0,30 & 0,16 & 0,37 & 0,14 & 0,86 \\
United Kingdom & 0,80 & 0,83 & 0,29 & 0,21 & 0,35 & 0,16 & 0,87 \\
& & & & & & & \\
\hline
\end{tabular}

Source: Gallup World Poll (2007-2009). Yes/No answers. Country averages. 


\section{Appendix}

Table A1. Estimates of Happiness and Life Satisfaction distinguishing First and Second Generation Immigrants.

UE immigrants only.

\begin{tabular}{|c|c|c|c|c|c|c|c|}
\hline & 1 & & 3 & & 5 & & 7 \\
\hline & & Natives & & 1st generation & & $2^{\text {nd }}$ generation & \\
\hline Age & $\begin{array}{l}-0.0712 * * * \\
(0.0110)\end{array}$ & Belgium & $\begin{array}{c}0.187 * * * \\
(0.0117)\end{array}$ & Belgium & $\begin{array}{l}0.0244 * * \\
(0.00776)\end{array}$ & Belgium & $\begin{array}{l}-0.0994 * * * \\
(0.0219)\end{array}$ \\
\hline Age square & $\begin{array}{l}0.0743^{* * *} \\
(0.0139)\end{array}$ & Switzerland & $\begin{array}{l}0.261^{* * *} \\
(0.0280)\end{array}$ & Switzerland & $\begin{array}{l}-0.202^{* * *} \\
(0.00220)\end{array}$ & Switzerland & $\begin{array}{l}-0.0708^{* * *} \\
(0.0150)\end{array}$ \\
\hline Male & $\begin{array}{l}-0.153^{* * *} \\
(0.0200)\end{array}$ & Germany & $\begin{array}{l}-0.322 * * * \\
(0.00906)\end{array}$ & Germany & $\begin{array}{l}0.0892^{* * *} \\
(0.00668)\end{array}$ & Germany & $\begin{array}{l}-0.0596 * * * \\
(0.00934)\end{array}$ \\
\hline Log household income & $\begin{array}{l}0.464 * * * \\
(0.0330)\end{array}$ & France & $\begin{array}{l}-0.311 * * * \\
(0.0091)\end{array}$ & France & $\begin{array}{l}0.247 * * * \\
(0.0102)\end{array}$ & France & $\begin{array}{l}0.102 * * * \\
(0.0129)\end{array}$ \\
\hline Married & $\begin{array}{l}-0.155^{*} \\
(0.0652)\end{array}$ & Great-Britain & $\begin{array}{c}-0.214 * * * \\
(0.00428)\end{array}$ & Great-Britain & $\begin{array}{l}-0.174 * * * \\
(0.0140)\end{array}$ & Great-Britain & $\begin{array}{l}-0.258^{* * *} \\
(0.00447)\end{array}$ \\
\hline Divorced & $\begin{array}{l}-0.407^{* * *} \\
(0.0998)\end{array}$ & Netherlands & $\begin{array}{l}0.126^{* * *} \\
(0.00348)\end{array}$ & Netherlands & $\begin{array}{l}0.0837^{* * *} * \\
(0.0142)\end{array}$ & Netherlands & $\begin{array}{l}0.208^{* * *} \\
(0.0217)\end{array}$ \\
\hline Log household income & $\begin{array}{l}0.354 * * * \\
(0.0536)\end{array}$ & Sweden & $\begin{array}{l}0.274 * * * \\
(0.00378)\end{array}$ & Sweden & $\begin{array}{l}-0.0678^{* * *} \\
(0.00964)\end{array}$ & Sweden & $\begin{array}{l}0.178^{* * *} \\
(0.00827)\end{array}$ \\
\hline Unemployed & $\begin{array}{l}-0.705^{* * *} \\
(0.129)\end{array}$ & & & & & & \\
\hline First generation immigrant & $\begin{array}{l}-0.0168 \\
(0.00888)\end{array}$ & & & & & & \\
\hline Second generation immigrant & $\begin{array}{l}-0.192 * * * \\
(0.0247)\end{array}$ & & & & & & \\
\hline Constant & $\begin{array}{l}6.430 * * * \\
(0.302)\end{array}$ & & & & & & \\
\hline Observations & 40.903 & & & & & & \\
\hline
\end{tabular}

Other controls: age, age square, marital status, male, log income, immigration status, employment status, year fixed-effects.

The coefficients of country fixed-effects reflect deviations from the "grand mean" rather than deviations from the reference category.

Robust standard errors clustered by country.

1.5 generation immigrants have been dropped from the sample. 


\section{Electronic Appendix}

Table E1.A OLS Estimates of Satisfaction viz. Different Domains. Distinguishing Natives. First and Second Generation Immigrants.

\begin{tabular}{|c|c|c|c|c|c|c|c|c|c|c|}
\hline & $(1)$ & & $(2)$ & $(3)$ & $(4)$ & $(5)$ & $(6)$ & $(7)$ & $(8)$ & $(9)$ \\
\hline & $\begin{array}{l}\text { Depressiveness } \\
\text { Index } \\
(0-59)\end{array}$ & $\begin{array}{c}\text { Life Satisfaction } \\
\text { Sflife } \\
(0-10)\end{array}$ & $\begin{array}{c}\text { Satisfaction with } \\
\text { Economy } \\
\text { (stfeco) } \\
(0-10)\end{array}$ & $\begin{array}{c}\text { Satisfaction with } \\
\text { national government } \\
\text { (stfgov) } \\
(0-10)\end{array}$ & $\begin{array}{c}\text { Satisfaction } \\
\text { with democracy } \\
\text { (stfdem) } \\
(0-10)\end{array}$ & $\begin{array}{c}\text { Satisfaction with } \\
\text { education system } \\
\text { (stfedu) } \\
(0-10)\end{array}$ & $\begin{array}{c}\text { Satisfaction } \\
\text { with Health } \\
\text { system } \\
(\text { stfhlth }) \\
(0-10)\end{array}$ & $\begin{array}{l}\text { Living comfortably } \\
\text { on present income } \\
\text { (bincfel) } \\
\text { (1-4) }\end{array}$ & $\begin{array}{c}\text { Hard to be } \\
\text { bopeful about the } \\
\text { future of the } \\
\text { world } \\
\text { (nhpftr) } \\
(1-5)\end{array}$ & $\begin{array}{c}\text { For most people in } \\
\text { country } \\
\text { life is getting worse } \\
\text { (lfwrs) } \\
(1-5)\end{array}$ \\
\hline Belgium & $\begin{array}{c}0.383 * * * \\
(0.0228)\end{array}$ & $\begin{array}{c}0.232 * * * \\
(0.0170)\end{array}$ & $\begin{array}{c}0.354 * * * \\
(0.00795)\end{array}$ & $\begin{array}{c}0.0101 \\
(0.0106)\end{array}$ & $\begin{array}{c}-0.126^{* * *} \\
(0.0123)\end{array}$ & $\begin{array}{c}0.993 * * * \\
(0.00975)\end{array}$ & $\begin{array}{c}1.454 * * * \\
(0.0118)\end{array}$ & $\begin{array}{c}0.0343 * * * \\
(0.00372)\end{array}$ & $\begin{array}{c}0.0293^{* * *} \\
(0.00201)\end{array}$ & $\begin{array}{c}0.0467^{* * *} \\
(0.00471)\end{array}$ \\
\hline Switzerland & $\begin{array}{c}-1.212^{* * *} \\
(0.0864)\end{array}$ & $\begin{array}{c}0.462^{* * *} \\
(0.0380)\end{array}$ & $\begin{array}{c}0.714 * * * \\
(0.0148)\end{array}$ & $\begin{array}{c}0.900^{* * *} \\
(0.0253)\end{array}$ & $\begin{array}{c}0.902 * * * \\
(0.0275)\end{array}$ & $\begin{array}{c}0.707 * * * \\
(0.0190)\end{array}$ & $\begin{array}{c}0.415^{* * *} \\
(0.0271)\end{array}$ & $\begin{array}{c}-0.0710^{* * *} \\
(0.00582)\end{array}$ & $\begin{array}{c}0.0256^{* * *} \\
(0.00665)\end{array}$ & $\begin{array}{c}-0.102 * * * \\
(0.0112)\end{array}$ \\
\hline Germany & $\begin{array}{c}-1.401^{* * *} \\
(0.0451)\end{array}$ & $\begin{array}{c}-0.336 * * * \\
(0.0134)\end{array}$ & $\begin{array}{l}-0.693 * * * \\
(0.00463)\end{array}$ & $\begin{array}{l}-0.860 * * * \\
(0.00570)\end{array}$ & $\begin{array}{c}-0.257 * * * \\
(0.00778)\end{array}$ & $\begin{array}{l}-1.182 * * * \\
(0.00553)\end{array}$ & $\begin{array}{c}-1.200 * * * \\
(0.00889)\end{array}$ & $\begin{array}{l}-0.105^{* * *} \\
(0.00264)\end{array}$ & $\begin{array}{l}0.143 * * * \\
(0.00337)\end{array}$ & $\begin{array}{l}0.286 * * * \\
(0.00526)\end{array}$ \\
\hline France & $\begin{array}{c}1.347 * * * \\
(0.0319)\end{array}$ & $\begin{array}{c}-0.869 * * * \\
(0.0130)\end{array}$ & $\begin{array}{c}-1.347^{* * *} \\
(0.0184)\end{array}$ & $\begin{array}{c}-0.610^{* * *} \\
(0.0230)\end{array}$ & $\begin{array}{c}-0.954 * * * \\
(0.0127)\end{array}$ & $\begin{array}{c}-0.649 * * * \\
(0.0108)\end{array}$ & $\begin{array}{c}0.0410^{* *} \\
(0.0165)\end{array}$ & $\begin{array}{c}-0.0247 * * \\
(0.00714)\end{array}$ & $\begin{array}{c}0.543 * * * \\
(0.00223)\end{array}$ & $\begin{array}{c}0.702 * * * \\
(0.00393)\end{array}$ \\
\hline UK & $\begin{array}{c}2.084 * * * \\
(0.0172)\end{array}$ & $\begin{array}{l}-0.315^{* * *} \\
(0.00442)\end{array}$ & $\begin{array}{c}-0.489 * * * \\
(0.0243)\end{array}$ & $\begin{array}{c}-0.502^{* * *} \\
(0.0125)\end{array}$ & $\begin{array}{l}-0.728 * * * \\
(0.00614)\end{array}$ & $\begin{array}{c}-0.0184^{* * *} \\
(0.00290)\end{array}$ & $\begin{array}{c}-0.464 * * * \\
(0.00696)\end{array}$ & $\begin{array}{c}-0.157^{* * *} \\
(0.00165)\end{array}$ & $\begin{array}{c}-0.121 * * * \\
(0.00165)\end{array}$ & $\begin{array}{c}-0.0800 * * * \\
(0.00278)\end{array}$ \\
\hline Netherlands & $\begin{array}{c}-0.565^{* * *} \\
(0.0317)\end{array}$ & $\begin{array}{c}0.298^{* * *} \\
(0.00810)\end{array}$ & $\begin{array}{c}0.803^{* * *} \\
(0.0197)\end{array}$ & $\begin{array}{c}0.408^{* * *} \\
(0.0107)\end{array}$ & $\begin{array}{c}0.453^{* * *} \\
(0.00399)\end{array}$ & $\begin{array}{c}0.265^{* * *} \\
(0.00474)\end{array}$ & $\begin{array}{c}0.0646^{* * *} \\
(0.00442)\end{array}$ & $\begin{array}{c}0.123 * * * \\
(0.00339)\end{array}$ & $\begin{array}{c}-0.313 * * * \\
(0.00201)\end{array}$ & $\begin{array}{l}-0.378^{* * *} \\
(0.00299)\end{array}$ \\
\hline Sweden & $\begin{array}{c}-0.635^{* * *} \\
(0.0368)\end{array}$ & $\begin{array}{l}0.528^{* * *} \\
(0.00652)\end{array}$ & $\begin{array}{c}0.658^{* * *} \\
(0.0185)\end{array}$ & $\begin{array}{c}0.655^{* * *} \\
(0.0138)\end{array}$ & $\begin{array}{c}0.709 * * * \\
(0.00936)\end{array}$ & $\begin{array}{l}-0.115^{* * *} \\
(0.00802)\end{array}$ & $\begin{array}{c}-0.310^{* * *} \\
(0.0147)\end{array}$ & $\begin{array}{c}0.201 * * * \\
(0.00407)\end{array}$ & $\begin{array}{c}-0.307 * * * \\
(0.00196)\end{array}$ & $\begin{array}{c}-0.476^{* * *} \\
(0.00198)\end{array}$ \\
\hline \multicolumn{11}{|c|}{1 st generation immigrants } \\
\hline Belgium & $\begin{array}{c}0.612^{* * *} \\
(0.162)\end{array}$ & $\begin{array}{c}-0.0804 * * * \\
(0.0119)\end{array}$ & $\begin{array}{c}-0.104 * * * \\
(0.0229)\end{array}$ & $\begin{array}{c}0.0950 * * * \\
(0.0201)\end{array}$ & $\begin{array}{c}-0.00974 \\
(0.0172)\end{array}$ & $\begin{array}{c}-0.423 * * * \\
(0.0151)\end{array}$ & $\begin{array}{c}-0.233 * * * \\
(0.0315)\end{array}$ & $\begin{array}{l}-0.125 * * * \\
(0.00581)\end{array}$ & $\begin{array}{c}0.271 * * * \\
(0.0173)\end{array}$ & $\begin{array}{c}0.107 * * * \\
(0.0240)\end{array}$ \\
\hline Switzerland & $\begin{array}{c}0.612 * * * \\
(0.138)\end{array}$ & $\begin{array}{c}-0.172^{* * *} \\
(0.0167)\end{array}$ & $\begin{array}{c}0.344^{* * *} \\
(0.0381)\end{array}$ & $\begin{array}{c}0.324 * * * \\
(0.0376)\end{array}$ & $\begin{array}{c}-0.103^{* *} \\
(0.0387)\end{array}$ & $\begin{array}{c}0.0923 * * \\
(0.0333)\end{array}$ & $\begin{array}{c}0.335^{* * *} \\
(0.0430)\end{array}$ & $\begin{array}{c}-0.0585^{* * *} \\
(0.0118)\end{array}$ & $\begin{array}{c}0.0629 * * \\
(0.0209)\end{array}$ & $\begin{array}{c}0.0923^{* *} \\
(0.0319)\end{array}$ \\
\hline Germany & $\begin{array}{c}-1.408^{* * *} \\
(0.247)\end{array}$ & $\begin{array}{c}0.249 * * * \\
(0.0338)\end{array}$ & $\begin{array}{c}0.213^{* * *} \\
(0.0293)\end{array}$ & $\begin{array}{c}0.191 * * * \\
(0.0354)\end{array}$ & $\begin{array}{c}0.191 * * * \\
(0.0458)\end{array}$ & $\begin{array}{c}0.248^{* * *} \\
(0.0191)\end{array}$ & $\begin{array}{c}0.601 * * * \\
(0.0434)\end{array}$ & $\begin{array}{c}0.0349 * * \\
(0.0134)\end{array}$ & $\begin{array}{c}-0.229 * * * \\
(0.0214)\end{array}$ & $\begin{array}{c}-0.193^{* * *} \\
(0.0306)\end{array}$ \\
\hline France & $\begin{array}{l}-0.354 \\
(0.220)\end{array}$ & $\begin{array}{c}0.0735^{* *} \\
(0.0212)\end{array}$ & $\begin{array}{l}0.0898^{*} \\
(0.0376)\end{array}$ & $\begin{array}{c}-0.146^{* *} \\
(0.0568)\end{array}$ & $\begin{array}{c}0.125^{* * *} \\
(0.0209)\end{array}$ & $\begin{array}{c}0.190^{* * *} \\
(0.0233)\end{array}$ & $\begin{array}{c}0.207 * * * \\
(0.0269)\end{array}$ & $\begin{array}{c}0.144 * * * \\
(0.0105)\end{array}$ & $\begin{array}{c}-0.0961 * * \\
(0.0373)\end{array}$ & $\begin{array}{c}-0.00196 \\
(0.0431)\end{array}$ \\
\hline $\mathrm{UK}$ & $\begin{array}{c}-1.485^{* * *} \\
(0.179)\end{array}$ & $\begin{array}{c}0.149 * * * \\
(0.0273)\end{array}$ & $\begin{array}{c}0.317 * * * \\
(0.0240)\end{array}$ & $\begin{array}{c}0.344 * * * \\
(0.0205)\end{array}$ & $\begin{array}{c}0.379 * * * \\
(0.0286)\end{array}$ & $\begin{array}{c}-0.271 * * * \\
(0.0216)\end{array}$ & $\begin{array}{c}-0.293 * * * \\
(0.0412)\end{array}$ & $\begin{array}{c}0.163^{* * *} \\
(0.00606)\end{array}$ & $\begin{array}{c}-0.128^{* * *} \\
(0.0163)\end{array}$ & $\begin{array}{c}-0.190 * * * \\
(0.0284)\end{array}$ \\
\hline
\end{tabular}




\begin{tabular}{|c|c|c|c|c|c|c|c|c|c|c|}
\hline Netherlands & $\begin{array}{c}1.054^{* * *} \\
(0.119)\end{array}$ & $\begin{array}{c}-0.107 * * * \\
(0.0201)\end{array}$ & $\begin{array}{c}-0.662 * * * \\
(0.0267)\end{array}$ & $\begin{array}{c}-0.420 * * * \\
(0.0292)\end{array}$ & $\begin{array}{c}-0.459 * * * \\
(0.0267)\end{array}$ & $\begin{array}{c}-0.139 * * * \\
(0.0178)\end{array}$ & $\begin{array}{c}-0.283^{* * *} \\
(0.0230)\end{array}$ & $\begin{array}{c}-0.147 * * * \\
(0.0110)\end{array}$ & $\begin{array}{c}0.109^{* * *} \\
(0.0150)\end{array}$ & $\begin{array}{c}0.191 * * * \\
(0.0244)\end{array}$ \\
\hline Sweden & $\begin{array}{c}0.968^{* * *} \\
(0.0610)\end{array}$ & $\begin{array}{c}-0.112 * * * \\
(0.0106)\end{array}$ & $\begin{array}{c}-0.198^{* * *} \\
(0.0187)\end{array}$ & $\begin{array}{c}-0.388^{* * *} \\
(0.0213)\end{array}$ & $\begin{array}{c}-0.124 * * * \\
(0.0170)\end{array}$ & $\begin{array}{c}0.302^{* * *} \\
(0.0135)\end{array}$ & $\begin{array}{c}-0.334 * * * \\
(0.0152)\end{array}$ & $\begin{array}{c}-0.0112 \\
(0.00634)\end{array}$ & $\begin{array}{c}0.0107 \\
(0.0152)\end{array}$ & $\begin{array}{c}-0.00453 \\
(0.0224)\end{array}$ \\
\hline \multicolumn{11}{|c|}{$2^{\text {nd }}$ generation immigrants } \\
\hline Belgium & $\begin{array}{c}-1.179 * * * \\
(0.181)\end{array}$ & $\begin{array}{c}-0.145^{* * *} \\
(0.0253)\end{array}$ & $\begin{array}{l}-0.0250 \\
(0.0248)\end{array}$ & $\begin{array}{c}0.160^{* * *} \\
(0.0234)\end{array}$ & $\begin{array}{c}-0.0505^{* * *} \\
(0.00813)\end{array}$ & $\begin{array}{c}-0.267 * * * \\
(0.0152)\end{array}$ & $\begin{array}{c}-0.151 * * * \\
(0.0220)\end{array}$ & $\begin{array}{c}-0.181 * * * \\
(0.00595)\end{array}$ & $\begin{array}{c}0.269^{* * *} \\
(0.0136)\end{array}$ & $\begin{array}{c}0.134 * * * \\
(0.0212)\end{array}$ \\
\hline Switzerland & $\begin{array}{c}0.836^{* *} \\
(0.254)\end{array}$ & $\begin{array}{c}-0.115^{* * *} \\
(0.0229)\end{array}$ & $\begin{array}{c}0.0233 \\
(0.0416)\end{array}$ & $\begin{array}{c}0.170^{* * *} \\
(0.0317)\end{array}$ & $\begin{array}{l}0.133^{* *} \\
(0.0432)\end{array}$ & $\begin{array}{c}0.0333 \\
(0.0443)\end{array}$ & $\begin{array}{c}0.446^{* * *} \\
(0.0510)\end{array}$ & $\begin{array}{c}-0.0345^{*} \\
(0.0170)\end{array}$ & $\begin{array}{c}0.260^{* * *} \\
(0.0233)\end{array}$ & $\begin{array}{c}0.252^{* * *} \\
(0.0436)\end{array}$ \\
\hline Germany & $\begin{array}{c}-1.041 * * * \\
(0.148)\end{array}$ & $\begin{array}{c}-0.153^{* * *} \\
(0.0206)\end{array}$ & $\begin{array}{c}-0.0506 * * \\
(0.0189)\end{array}$ & $\begin{array}{c}0.212^{* * *} \\
(0.0341)\end{array}$ & $\begin{array}{c}0.0844^{* *} \\
(0.0282)\end{array}$ & $\begin{array}{c}0.516^{* * *} \\
(0.00846)\end{array}$ & $\begin{array}{c}0.515^{* * *} \\
(0.0140)\end{array}$ & $\begin{array}{c}-0.0765^{* * *} \\
(0.00747)\end{array}$ & $\begin{array}{c}-0.204 * * * \\
(0.0118)\end{array}$ & $\begin{array}{l}-0.0404 \\
(0.0244)\end{array}$ \\
\hline France & $\begin{array}{l}0.0831 \\
(0.213)\end{array}$ & $\begin{array}{c}0.255^{* * *} \\
(0.0220)\end{array}$ & $\begin{array}{c}0.258^{* * *} \\
(0.0370)\end{array}$ & $\begin{array}{c}-0.313^{* * *} \\
(0.0507)\end{array}$ & $\begin{array}{c}0.0153 \\
(0.0175)\end{array}$ & $\begin{array}{c}0.185^{* * *} \\
(0.0232)\end{array}$ & $\begin{array}{c}0.0346 \\
(0.0463)\end{array}$ & $\begin{array}{c}0.127 * * * \\
(0.0105)\end{array}$ & $\begin{array}{l}-0.0389 \\
(0.0308)\end{array}$ & $\begin{array}{c}-0.283^{* * *} \\
(0.0390)\end{array}$ \\
\hline UK & $\begin{array}{c}0.139 \\
(0.363)\end{array}$ & $\begin{array}{c}-0.329 * * * \\
(0.0303)\end{array}$ & $\begin{array}{c}0.228 * * * \\
(0.0385)\end{array}$ & $\begin{array}{c}0.248^{* * *} \\
(0.0350)\end{array}$ & $\begin{array}{c}0.0243 \\
(0.0349)\end{array}$ & $\begin{array}{c}-0.212 * * * \\
(0.0300)\end{array}$ & $\begin{array}{c}-0.391 * * * \\
(0.0596)\end{array}$ & $\begin{array}{c}0.108^{* * *} \\
(0.0112)\end{array}$ & $\begin{array}{c}0.0770^{* *} \\
(0.0214)\end{array}$ & $\begin{array}{c}0.254^{* * *} \\
(0.0426)\end{array}$ \\
\hline Netherlands & $\begin{array}{c}1.463 * * * \\
(0.346)\end{array}$ & $\begin{array}{c}0.305^{* * *} \\
(0.0448)\end{array}$ & $\begin{array}{c}-0.642 * * * \\
(0.0594)\end{array}$ & $\begin{array}{c}-0.359 * * * \\
(0.0439)\end{array}$ & $\begin{array}{c}-0.239 * * * \\
(0.0547)\end{array}$ & $\begin{array}{c}-0.414 * * * \\
(0.0524)\end{array}$ & $\begin{array}{l}-0.0969 \\
(0.0848)\end{array}$ & $\begin{array}{l}-0.0277 \\
(0.0184)\end{array}$ & $\begin{array}{c}0.0133 \\
(0.0250)\end{array}$ & $\begin{array}{l}-0.0157 \\
(0.0533)\end{array}$ \\
\hline Sweden & $\begin{array}{l}-0.300 \\
(0.206)\end{array}$ & $\begin{array}{c}0.182 * * * \\
(0.0214)\end{array}$ & $\begin{array}{c}0.209^{* * *} \\
(0.0381)\end{array}$ & $\begin{array}{c}-0.118^{* *} \\
(0.0385)\end{array}$ & $\begin{array}{c}0.0322 \\
(0.0388)\end{array}$ & $\begin{array}{c}0.159^{* * *} \\
(0.0319)\end{array}$ & $\begin{array}{c}-0.357 * * * \\
(0.0470)\end{array}$ & $\begin{array}{c}0.0850^{* * *} \\
(0.0122)\end{array}$ & $\begin{array}{c}-0.376 \text { *** } \\
(0.0214)\end{array}$ & $\begin{array}{c}-0.301 * * * \\
(0.0284)\end{array}$ \\
\hline 1st generation & $\begin{array}{c}0.878^{* * *} \\
(0.184)\end{array}$ & $\begin{array}{c}-0.290^{* * *} \\
(0.0136)\end{array}$ & $\begin{array}{c}0.253 * * * \\
(0.0536)\end{array}$ & $\begin{array}{c}0.505^{* * *} \\
(0.0451)\end{array}$ & $\begin{array}{c}0.515^{* * *} \\
(0.0363)\end{array}$ & $\begin{array}{c}-0.190^{* * *} \\
(0.0394)\end{array}$ & $\begin{array}{c}0.145^{* * *} \\
(0.0375)\end{array}$ & $\begin{array}{c}-0.225^{* * *} \\
(0.0164)\end{array}$ & $\begin{array}{c}0.241 * * * \\
(0.0298)\end{array}$ & $\begin{array}{c}0.0590 \\
(0.0528)\end{array}$ \\
\hline $2^{\text {nd }}$ generation & $\begin{array}{c}-0.638^{* * *} \\
(0.123)\end{array}$ & $\begin{array}{c}-0.307 * * * \\
(0.0297)\end{array}$ & $\begin{array}{c}-0.163 * * \\
(0.0551)\end{array}$ & $\begin{array}{c}0.0176 \\
(0.0565)\end{array}$ & $\begin{array}{l}-0.0370 \\
(0.0473)\end{array}$ & $\begin{array}{c}-0.519 * * * \\
(0.0450)\end{array}$ & $\begin{array}{c}-0.177^{* *} \\
(0.0618)\end{array}$ & $\begin{array}{c}-0.265^{* * *} \\
(0.0152)\end{array}$ & $\begin{array}{c}0.265 * * * \\
(0.0207)\end{array}$ & $\begin{array}{c}0.221 * * * \\
(0.0457)\end{array}$ \\
\hline Constant & $\begin{array}{c}15.89 * * * \\
(0.969)\end{array}$ & $\begin{array}{c}5.651 * * * \\
(0.289)\end{array}$ & $\begin{array}{c}2.710^{* * *} \\
(0.665)\end{array}$ & $\begin{array}{c}3.549 * * * \\
(0.313)\end{array}$ & $\begin{array}{c}3.581 * * * \\
(0.237)\end{array}$ & $\begin{array}{c}7.586^{* * *} \\
(0.331)\end{array}$ & $\begin{array}{c}6.613^{* * *} \\
(0.448)\end{array}$ & $\begin{array}{l}0.371^{*} \\
(0.181)\end{array}$ & $\begin{array}{c}3.793 * * * \\
(0.201)\end{array}$ & $\begin{array}{c}4.327 * * * \\
(0.316)\end{array}$ \\
\hline Observations & 8.369 & 44,422 & 43.998 & 43.620 & 43.740 & 43.264 & 44.229 & 42.425 & 8.988 & 8.378 \\
\hline R-squared & 0.110 & 0.149 & 0.182 & 0.113 & 0.124 & 0.121 & 0.147 & 0.282 & 0.112 & 0.194 \\
\hline
\end{tabular}

Other controls: age, age square, marital status, male, log income, region of origin, migration status, employment status, year fixed-effects.

Variables recoded in ascending order when necessary.

The coefficients of country fixed-effects reflect deviations from the "grand mean" rather than deviations from the reference category.

Robust standard errors clustered by country. 
Table E1.B OLS Estimates of Satisfaction viz. Different Domains. Immigrants from EU only.

\begin{tabular}{|c|c|c|c|c|c|c|c|c|c|c|}
\hline & $(1)$ & & $(2)$ & (3) & $(4)$ & (5) & $(6)$ & $(7)$ & (8) & $(18)$ \\
\hline & $\begin{array}{l}\text { Depressiveness } \\
\text { Index } \\
(0-59)\end{array}$ & $\begin{array}{c}\text { Life } \\
\text { Satisfaction } \\
\text { Sflife } \\
0-10\end{array}$ & $\begin{array}{c}\text { Satisfaction } \\
\text { with Economy } \\
\text { (stfeco) } \\
(0-10)\end{array}$ & $\begin{array}{c}\text { Satisfaction with } \\
\text { national } \\
\text { government } \\
\text { (stfgov) } \\
(0-10)\end{array}$ & $\begin{array}{c}\text { Satisfaction with } \\
\text { democracy } \\
\text { (stfdem) } \\
(0-10)\end{array}$ & $\begin{array}{c}\text { Satisfaction with } \\
\text { education system } \\
\text { (stfedu) } \\
(0-10)\end{array}$ & $\begin{array}{c}\text { Satisfaction } \\
\text { with Health } \\
\text { system } \\
\text { (stfhlth) } \\
(0-10)\end{array}$ & $\begin{array}{c}\text { Living } \\
\text { comfortably on } \\
\text { present income } \\
\text { (bincfel) } \\
\text { (1-4) }\end{array}$ & $\begin{array}{l}\text { Hard to be hopeful } \\
\text { about the future of the } \\
\text { world } \\
\text { (nhpftr) } \\
(1-5)\end{array}$ & $\begin{array}{l}\text { For most people in } \\
\text { country } \\
\text { life is getting worse } \\
\text { (Ifwrrs) } \\
(1-5)\end{array}$ \\
\hline Belgium & $\begin{array}{c}0.353^{* * *} \\
(0.0203)\end{array}$ & $\begin{array}{c}0.235^{* * *} \\
(0.0183)\end{array}$ & $\begin{array}{l}0.359 * * * \\
(0.00863)\end{array}$ & $\begin{array}{c}0.0166 \\
(0.0112)\end{array}$ & $\begin{array}{c}-0.114^{* * *} \\
(0.0140)\end{array}$ & $\begin{array}{c}1.008^{* * *} \\
(0.0105)\end{array}$ & $\begin{array}{c}1.462^{* * *} \\
(0.0106)\end{array}$ & $\begin{array}{c}0.0359 * * * \\
(0.00349)\end{array}$ & $\begin{array}{c}0.0235^{* * *} \\
(0.00208)\end{array}$ & $\begin{array}{c}0.0396^{* * *} \\
(0.00482)\end{array}$ \\
\hline Switzerland & $\begin{array}{c}-1.204 * * * \\
(0.0840)\end{array}$ & $\begin{array}{c}0.462 * * * \\
(0.0413)\end{array}$ & $\begin{array}{c}0.703 * * * \\
(0.0186)\end{array}$ & $\begin{array}{c}0.881 * * * \\
(0.0278)\end{array}$ & $\begin{array}{c}0.883 * * * \\
(0.0315)\end{array}$ & $\begin{array}{c}0.689 * * * \\
(0.0215)\end{array}$ & $\begin{array}{c}0.394 * * * \\
(0.0251)\end{array}$ & $\begin{array}{c}-0.0720 * * * \\
(0.00551)\end{array}$ & $\begin{array}{c}0.0267 * * * \\
(0.00631)\end{array}$ & $\begin{array}{c}-0.0954 * * * \\
(0.0109)\end{array}$ \\
\hline Germany & $\begin{array}{c}-1.419 * * * \\
(0.0440)\end{array}$ & $\begin{array}{c}-0.337 * * * \\
(0.0139)\end{array}$ & $\begin{array}{c}-0.689^{* * *} \\
(0.00550)\end{array}$ & $\begin{array}{l}-0.856^{* * *} \\
(0.00645)\end{array}$ & $\begin{array}{l}-0.252 * * * \\
(0.00861)\end{array}$ & $\begin{array}{l}-1.181^{* * *} \\
(0.00608)\end{array}$ & $\begin{array}{c}-1.196 * * * \\
(0.00897)\end{array}$ & $\begin{array}{c}-0.105^{* * *} \\
(0.00268)\end{array}$ & $\begin{array}{l}0.143 * * * \\
(0.00372)\end{array}$ & $\begin{array}{l}0.282^{* * *} \\
(0.00552)\end{array}$ \\
\hline France & $\begin{array}{l}1.343 * * * \\
(0.0327)\end{array}$ & $\begin{array}{c}-0.870 * * * \\
(0.0143)\end{array}$ & $\begin{array}{c}-1.343^{* * *} \\
(0.0206)\end{array}$ & $\begin{array}{c}-0.602 * * * \\
(0.0252)\end{array}$ & $\begin{array}{c}-0.950 * * * \\
(0.0149)\end{array}$ & $\begin{array}{c}-0.642^{* * *} \\
(0.0113)\end{array}$ & $\begin{array}{c}0.0471 * * \\
(0.0156)\end{array}$ & $\begin{array}{c}-0.0262^{* *} \\
(0.00826)\end{array}$ & $\begin{array}{l}0.542 * * * \\
(0.00209)\end{array}$ & $\begin{array}{l}0.698 * * * \\
(0.00376)\end{array}$ \\
\hline Great-Britain & $\begin{array}{c}2.102 * * * \\
(0.0161)\end{array}$ & $\begin{array}{l}-0.312^{* * *} \\
(0.00449)\end{array}$ & $\begin{array}{c}-0.493^{* * * *} \\
(0.0238)\end{array}$ & $\begin{array}{c}-0.504 * * * \\
(0.0122)\end{array}$ & $\begin{array}{l}-0.731^{* * *} \\
(0.00626)\end{array}$ & $\begin{array}{c}-0.0178^{* * *} \\
(0.00308)\end{array}$ & $\begin{array}{l}-0.461 * * * \\
(0.00757)\end{array}$ & $\begin{array}{l}-0.158^{* * *} \\
(0.00152)\end{array}$ & $\begin{array}{c}-0.116^{* * *} \\
(0.00148)\end{array}$ & $\begin{array}{c}-0.0722 * * * \\
(0.00270)\end{array}$ \\
\hline Netherlands & $\begin{array}{c}-0.563 * * * \\
(0.0306)\end{array}$ & $\begin{array}{l}0.295 * * * \\
(0.00952)\end{array}$ & $\begin{array}{c}0.806 * * * \\
(0.0206)\end{array}$ & $\begin{array}{l}0.413^{* * *} \\
(0.00970)\end{array}$ & $\begin{array}{l}0.455^{* * *} \\
(0.00517)\end{array}$ & $\begin{array}{l}0.265 * * * \\
(0.00612)\end{array}$ & $\begin{array}{c}0.0660^{* * *} \\
(0.00568)\end{array}$ & $\begin{array}{l}0.123 * * * \\
(0.00345)\end{array}$ & $\begin{array}{l}-0.314 * * * \\
(0.00185)\end{array}$ & $\begin{array}{l}-0.376^{* * *} \\
(0.00263)\end{array}$ \\
\hline Sweden & $\begin{array}{c}-0.612^{* * *} \\
(0.0299)\end{array}$ & $\begin{array}{l}0.527 * * * \\
(0.00643)\end{array}$ & $\begin{array}{c}0.658^{* * *} \\
(0.0189)\end{array}$ & $\begin{array}{c}0.652^{* * *} \\
(0.0152)\end{array}$ & $\begin{array}{c}0.708^{* * *} \\
(0.0111)\end{array}$ & $\begin{array}{l}-0.121^{* * *} \\
(0.00941)\end{array}$ & $\begin{array}{c}-0.311^{* * *} \\
(0.0155)\end{array}$ & $\begin{array}{l}0.202^{* * *} \\
(0.00401)\end{array}$ & $\begin{array}{l}-0.305^{* * *} \\
(0.00234)\end{array}$ & $\begin{array}{l}-0.476^{* * *} \\
(0.00296)\end{array}$ \\
\hline \multicolumn{11}{|c|}{1 st generation immigrants } \\
\hline Belgium & $\begin{array}{c}0.753^{* * *} \\
(0.0540)\end{array}$ & $\begin{array}{c}-0.0850 * * * \\
(0.00769)\end{array}$ & $\begin{array}{c}-0.354^{* * *} \\
(0.0175)\end{array}$ & $\begin{array}{c}-0.130^{* * *} \\
(0.0132)\end{array}$ & $\begin{array}{l}-0.168 * * * \\
(0.00806)\end{array}$ & $\begin{array}{l}-0.456 * * * \\
(0.00794)\end{array}$ & $\begin{array}{c}-0.232 * * * \\
(0.0110)\end{array}$ & $\begin{array}{l}-0.165^{* * *} \\
(0.00175)\end{array}$ & $\begin{array}{l}0.120^{* * *} \\
(0.00274)\end{array}$ & $\begin{array}{c}0.125^{* * *} \\
(0.0102)\end{array}$ \\
\hline Switzerland & $\begin{array}{c}0.942^{* * *} \\
(0.0248)\end{array}$ & $\begin{array}{c}-0.152 * * * \\
(0.00216)\end{array}$ & $\begin{array}{l}0.312 * * * \\
(0.00977)\end{array}$ & $\begin{array}{c}0.380 * * * \\
(0.0109)\end{array}$ & $\begin{array}{c}-0.120 * * * \\
(0.00785)\end{array}$ & $\begin{array}{c}0.0590 * * * \\
(0.00502)\end{array}$ & $\begin{array}{l}0.329 * * * \\
(0.00607)\end{array}$ & $\begin{array}{c}-0.0577^{* * *} \\
(0.00187)\end{array}$ & $\begin{array}{c}0.0517^{* * *} \\
(0.00310)\end{array}$ & $\begin{array}{l}0.122 * * * \\
(0.00392)\end{array}$ \\
\hline Germany & $\begin{array}{c}-2.572 * * * \\
(0.0348)\end{array}$ & $\begin{array}{l}0.317 * * * \\
(0.00952)\end{array}$ & $\begin{array}{c}0.248^{* * *} \\
(0.0124)\end{array}$ & $\begin{array}{c}0.258^{* * *} \\
(0.0113)\end{array}$ & $\begin{array}{c}0.293 * * * \\
(0.0126)\end{array}$ & $\begin{array}{c}-0.0729 * * * \\
(0.00976)\end{array}$ & $\begin{array}{l}0.389 * * * \\
(0.00583)\end{array}$ & $\begin{array}{c}0.0798 * * * \\
(0.00464)\end{array}$ & $\begin{array}{c}-0.206 * * * \\
(0.00736)\end{array}$ & $\begin{array}{c}-0.183 * * * \\
(0.00805)\end{array}$ \\
\hline France & $\begin{array}{l}-0.0549 \\
(0.0722)\end{array}$ & $\begin{array}{c}0.0379 * * \\
(0.0150)\end{array}$ & $\begin{array}{l}0.0918^{*} \\
(0.0463)\end{array}$ & $\begin{array}{c}0.0251 \\
(0.0245)\end{array}$ & $\begin{array}{c}0.0111 \\
(0.0125)\end{array}$ & $\begin{array}{l}0.553 * * * \\
(0.00883)\end{array}$ & $\begin{array}{l}0.269 * * * \\
(0.00841)\end{array}$ & $\begin{array}{l}0.110^{* * *} \\
(0.00518)\end{array}$ & $\begin{array}{l}-0.166 * * * \\
(0.00664)\end{array}$ & $\begin{array}{c}0.00356 \\
(0.00879)\end{array}$ \\
\hline Great-Britain & $\begin{array}{c}-1.411 * * * \\
(0.0479)\end{array}$ & $\begin{array}{c}-0.109 * * * \\
(0.0220)\end{array}$ & $\begin{array}{l}0.104 * * \\
(0.0317)\end{array}$ & $\begin{array}{c}0.0737 * * * \\
(0.0163)\end{array}$ & $\begin{array}{c}0.0645 * * * \\
(0.0124)\end{array}$ & $\begin{array}{c}-0.334 * * * \\
(0.0119)\end{array}$ & $\begin{array}{l}-0.516^{* * *} \\
(0.00977)\end{array}$ & $\begin{array}{c}0.0668^{* * *} \\
(0.00617)\end{array}$ & $\begin{array}{l}0.0204 * * \\
(0.00603)\end{array}$ & $\begin{array}{c}-0.0605 * * * \\
(0.00983)\end{array}$ \\
\hline Netherlands & $\begin{array}{c}2.238^{* * *} \\
(0.108)\end{array}$ & $\begin{array}{c}0.0887 * * * \\
(0.0158)\end{array}$ & $\begin{array}{c}-0.138^{* * *} \\
(0.0132)\end{array}$ & $\begin{array}{c}-0.175^{* * *} \\
(0.0153)\end{array}$ & $\begin{array}{l}-0.00127 \\
(0.00728)\end{array}$ & $\begin{array}{c}0.207 * * * \\
(0.0123)\end{array}$ & $\begin{array}{c}0.0803 * * * \\
(0.0140)\end{array}$ & $\begin{array}{c}-0.0210^{* * *} \\
(0.00192)\end{array}$ & $\begin{array}{l}0.152^{* * *} \\
(0.00450)\end{array}$ & $\begin{array}{l}0.208^{* * *} \\
(0.00931)\end{array}$ \\
\hline Sweden & $\begin{array}{l}0.106^{* *} \\
(0.0382)\end{array}$ & $\begin{array}{c}-0.0984 * * * \\
(0.0134)\end{array}$ & $\begin{array}{c}-0.264 * * * \\
(0.0122)\end{array}$ & $\begin{array}{c}-0.432^{* * *} \\
(0.0108)\end{array}$ & $\begin{array}{c}-0.0793^{* * *} \\
(0.0108)\end{array}$ & $\begin{array}{c}0.0447 * * \\
(0.0130)\end{array}$ & $\begin{array}{c}-0.320 * * * \\
(0.0106)\end{array}$ & $\begin{array}{l}-0.0127^{*} \\
(0.00535)\end{array}$ & $\begin{array}{c}0.0286^{* * *} \\
(0.00391)\end{array}$ & $\begin{array}{l}-0.216^{* * *} \\
(0.00675)\end{array}$ \\
\hline
\end{tabular}




\begin{tabular}{|c|c|c|c|c|c|c|c|c|c|c|}
\hline \multicolumn{11}{|c|}{$2^{\text {nd }}$ generation immigrants } \\
\hline Belgium & $\begin{array}{c}-1.495^{* * *} \\
(0.0399)\end{array}$ & $\begin{array}{c}-0.145^{* * *} \\
(0.0308)\end{array}$ & $\begin{array}{c}-0.290 * * * \\
(0.0353)\end{array}$ & $\begin{array}{l}-0.0313 \\
(0.0245)\end{array}$ & $\begin{array}{c}-0.248 * * * \\
(0.0162)\end{array}$ & $\begin{array}{c}-0.235^{* * *} \\
(0.0112)\end{array}$ & $\begin{array}{c}-0.0947 * * * \\
(0.0115)\end{array}$ & $\begin{array}{c}-0.333^{* * *} \\
(0.00906)\end{array}$ & $\begin{array}{l}0.356^{* * *} \\
(0.00424)\end{array}$ & $\begin{array}{c}0.351 * * * \\
(0.00687)\end{array}$ \\
\hline Switzerland & $\begin{array}{l}-0.0752 \\
(0.0555)\end{array}$ & $\begin{array}{c}-0.0625^{* *} \\
(0.0191)\end{array}$ & $\begin{array}{c}-0.199 * * * \\
(0.0142)\end{array}$ & $\begin{array}{c}0.0491 * * * \\
(0.00918)\end{array}$ & $\begin{array}{c}-0.0357 * * \\
(0.0146)\end{array}$ & $\begin{array}{c}-0.0656^{* * *} \\
(0.0115)\end{array}$ & $\begin{array}{c}0.256 * * * \\
(0.0169)\end{array}$ & $\begin{array}{c}0.0275^{* *} \\
(0.00790)\end{array}$ & $\begin{array}{l}0.314 * * * \\
(0.00638)\end{array}$ & $\begin{array}{c}0.361 * * * \\
(0.00779)\end{array}$ \\
\hline Germany & $\begin{array}{c}0.222 * * * \\
(0.0422)\end{array}$ & $\begin{array}{l}-0.196 * * * \\
(0.00688)\end{array}$ & $\begin{array}{c}-0.142^{* * *} \\
(0.0216)\end{array}$ & $\begin{array}{c}0.114^{* * *} \\
(0.0188)\end{array}$ & $\begin{array}{l}-0.146 * * * \\
(0.00653)\end{array}$ & $\begin{array}{c}0.518^{* * *} \\
(0.00996)\end{array}$ & $\begin{array}{l}0.0316^{*} \\
(0.0139)\end{array}$ & $\begin{array}{c}-0.0323 * * * \\
(0.00318)\end{array}$ & $\begin{array}{c}-0.0142 * * \\
(0.00442)\end{array}$ & $\begin{array}{c}-0.0619 * * * \\
(0.00448)\end{array}$ \\
\hline France & $\begin{array}{c}0.439 * * * \\
(0.0873)\end{array}$ & $\begin{array}{c}0.0994 * * * \\
(0.0147)\end{array}$ & $\begin{array}{c}-0.0587 * * * \\
(0.0111)\end{array}$ & $\begin{array}{c}-0.149 * * * \\
(0.0182)\end{array}$ & $\begin{array}{c}-0.368 * * * \\
(0.0160)\end{array}$ & $\begin{array}{c}-0.0966 * * * \\
(0.00670)\end{array}$ & $\begin{array}{c}-0.277^{* * *} \\
(0.0191)\end{array}$ & $\begin{array}{c}0.0213^{*} \\
(0.00890)\end{array}$ & $\begin{array}{l}0.369 * * * \\
(0.00672)\end{array}$ & $\begin{array}{l}0.146^{* * *} \\
(0.00880)\end{array}$ \\
\hline Great-Britain & $\begin{array}{c}-1.050^{* * *} \\
(0.0638)\end{array}$ & $\begin{array}{c}-0.184 * * * \\
(0.00833)\end{array}$ & $\begin{array}{c}0.246^{* * *} \\
(0.0261)\end{array}$ & $\begin{array}{c}0.379 * * * \\
(0.0229)\end{array}$ & $\begin{array}{l}0.143 * * * \\
(0.00929)\end{array}$ & $\begin{array}{c}-0.113 * * * \\
(0.0114)\end{array}$ & $\begin{array}{c}-0.146 * * * \\
(0.0134)\end{array}$ & $\begin{array}{c}0.0268^{* * *} \\
(0.00397)\end{array}$ & $\begin{array}{c}-0.663 * * * \\
(0.0154)\end{array}$ & $\begin{array}{c}-0.725^{* * *} \\
(0.0109)\end{array}$ \\
\hline Netherlands & $\begin{array}{c}3.804 * * * \\
(0.145)\end{array}$ & $\begin{array}{c}0.289 * * * \\
(0.0323)\end{array}$ & $\begin{array}{c}0.417 * * * \\
(0.0323)\end{array}$ & $\begin{array}{c}-0.237 * * * \\
(0.0299)\end{array}$ & $\begin{array}{c}0.783 * * * \\
(0.0234)\end{array}$ & $\begin{array}{l}-0.0111 \\
(0.0161)\end{array}$ & $\begin{array}{c}0.790 * * * \\
(0.0364)\end{array}$ & $\begin{array}{l}0.204 * * * \\
(0.00600)\end{array}$ & $\begin{array}{c}-0.128^{* * *} \\
(0.0214)\end{array}$ & $\begin{array}{c}0.0933 * * * \\
(0.0116)\end{array}$ \\
\hline Sweden & $\begin{array}{c}-1.844^{* * *} \\
(0.0960)\end{array}$ & $\begin{array}{c}0.198^{* * *} \\
(0.00528)\end{array}$ & $\begin{array}{c}0.0270 \\
(0.0172)\end{array}$ & $\begin{array}{c}-0.124 * * * \\
(0.0170)\end{array}$ & $\begin{array}{c}-0.129 * * * \\
(0.00919)\end{array}$ & $\begin{array}{c}0.00373 \\
(0.00802)\end{array}$ & $\begin{array}{c}-0.560 * * * \\
(0.00430)\end{array}$ & $\begin{array}{c}0.0852^{* * *} \\
(0.00409)\end{array}$ & $\begin{array}{c}-0.234 * * * \\
(0.00564)\end{array}$ & $\begin{array}{c}-0.164 * * * \\
(0.00916)\end{array}$ \\
\hline 1st generation & $\begin{array}{c}0.949 * * * \\
(0.0665)\end{array}$ & $\begin{array}{c}-0.264^{* * *} \\
(0.0158)\end{array}$ & $\begin{array}{l}-0.0229 \\
(0.0231)\end{array}$ & $\begin{array}{c}0.155^{* * *} \\
(0.0172)\end{array}$ & $\begin{array}{c}0.301 * * * \\
(0.0123)\end{array}$ & $\begin{array}{c}-0.232^{* * *} \\
(0.00859)\end{array}$ & $\begin{array}{c}0.120^{* * *} \\
(0.0225)\end{array}$ & $\begin{array}{c}-0.221 * * * \\
(0.00261)\end{array}$ & $\begin{array}{c}0.0997 * * * \\
(0.00398)\end{array}$ & $\begin{array}{c}0.0971^{* * *} \\
(0.0120)\end{array}$ \\
\hline 2nd-generation & $\begin{array}{c}0.0169 \\
(0.0480)\end{array}$ & $\begin{array}{c}-0.314 * * * \\
(0.0327)\end{array}$ & $\begin{array}{c}-0.203^{* * *} \\
(0.0383)\end{array}$ & $\begin{array}{l}-0.0250 \\
(0.0230)\end{array}$ & $\begin{array}{c}-0.0343^{*} \\
(0.0167)\end{array}$ & $\begin{array}{c}-0.394 * * * \\
(0.0121)\end{array}$ & $\begin{array}{c}0.0911 * * * \\
(0.0141)\end{array}$ & $\begin{array}{c}-0.463 * * * \\
(0.00608)\end{array}$ & $\begin{array}{l}0.284 * * * \\
(0.00349)\end{array}$ & $\begin{array}{c}0.298 * * * \\
(0.00703)\end{array}$ \\
\hline Constant & $\begin{array}{c}15.73 * * * \\
(1.026)\end{array}$ & $\begin{array}{c}5.539 * * * \\
(0.341)\end{array}$ & $\begin{array}{c}3.014^{* * *} \\
(0.666)\end{array}$ & $\begin{array}{c}3.666 * * * \\
(0.342)\end{array}$ & $\begin{array}{c}3.526 * * * \\
(0.243)\end{array}$ & $\begin{array}{c}7.183^{* * *} \\
(0.329)\end{array}$ & $\begin{array}{c}6.0311^{* * *} \\
(0.418)\end{array}$ & $\begin{array}{c}0.662^{* * *} \\
(0.160)\end{array}$ & $\begin{array}{c}3.936^{* * *} \\
(0.164)\end{array}$ & $\begin{array}{c}4.299 * * * \\
(0.245)\end{array}$ \\
\hline Observations & 7.738 & 40,910 & 40.544 & 40.250 & 40.337 & 39.886 & 40.744 & 39.054 & 8.292 & 7.733 \\
\hline R-squared & 0.108 & 0.151 & 0.189 & 0.113 & 0.125 & 0.123 & 0.148 & 0.269 & 0.115 & 0.202 \\
\hline
\end{tabular}

Other controls: age, age square, marital status, male, log income, migration status, employment status, year fixed-effects.

Variables recoded in ascending order when necessary.

The coefficients of country fixed-effects reflect deviations from the "grand mean" rather than deviations from the reference category.

Robust standard errors clustered by country. 


\section{Electronic Appendix}

Table E1.A OLS Estimates of Satisfaction viz. Different Domains. Distinguishing Natives. First and Second Generation Immigrants.

\begin{tabular}{|c|c|c|c|c|c|c|c|c|c|c|}
\hline & $(1)$ & & $(2)$ & (3) & (4) & (5) & $(6)$ & $(7)$ & $(8)$ & $(9)$ \\
\hline & $\begin{array}{c}\text { Depressiveness } \\
\text { Index } \\
(0-59)\end{array}$ & $\begin{array}{c}\text { Life Satisfaction } \\
\text { Sflife } \\
(0-10)\end{array}$ & $\begin{array}{c}\text { Satisfaction with } \\
\text { Economy } \\
\text { (stfeco) } \\
(0-10)\end{array}$ & $\begin{array}{c}\text { Satisfaction with } \\
\text { national government } \\
\text { (stfgov) } \\
(0-10)\end{array}$ & $\begin{array}{c}\text { Satisfaction } \\
\text { with democracy } \\
\text { (stfdem) } \\
(0-10)\end{array}$ & $\begin{array}{c}\text { Satisfaction with } \\
\text { education system } \\
\text { (stfedu) } \\
(0-10)\end{array}$ & $\begin{array}{c}\text { Satisfaction } \\
\text { with Health } \\
\text { system } \\
(\text { stfhlth }) \\
(0-10)\end{array}$ & $\begin{array}{l}\text { Living comfortably } \\
\text { on present income } \\
\text { (bincfel) } \\
(1-4)\end{array}$ & $\begin{array}{c}\text { Hard to be } \\
\text { hopeful about the } \\
\text { future of the } \\
\text { world } \\
\text { (nhpftr) } \\
(1-5)\end{array}$ & $\begin{array}{c}\text { For most people in } \\
\text { country } \\
\text { life is getting worse } \\
\text { (Ifwrs) } \\
(1-5)\end{array}$ \\
\hline Belgium & $\begin{array}{c}0.383^{* * *} \\
(0.0228)\end{array}$ & $\begin{array}{c}0.232^{* * *} \\
(0.0170)\end{array}$ & $\begin{array}{l}0.354^{* * *} \\
(0.00795)\end{array}$ & $\begin{array}{c}0.0101 \\
(0.0106)\end{array}$ & $\begin{array}{c}-0.126^{* * *} \\
(0.0123)\end{array}$ & $\begin{array}{l}0.993 * * * \\
(0.00975)\end{array}$ & $\begin{array}{c}1.454^{* * *} \\
(0.0118)\end{array}$ & $\begin{array}{c}0.0343 * * * \\
(0.00372)\end{array}$ & $\begin{array}{c}0.0293^{* * *} * \\
(0.00201)\end{array}$ & $\begin{array}{c}0.0467 * * * \\
(0.00471)\end{array}$ \\
\hline Switzerland & $\begin{array}{c}-1.212^{* * *} \\
(0.0864)\end{array}$ & $\begin{array}{c}0.462 * * * \\
(0.0380)\end{array}$ & $\begin{array}{c}0.714^{* * *} \\
(0.0148)\end{array}$ & $\begin{array}{c}0.900^{* * *} \\
(0.0253)\end{array}$ & $\begin{array}{c}0.902 * * * \\
(0.0275)\end{array}$ & $\begin{array}{c}0.707 * * * \\
(0.0190)\end{array}$ & $\begin{array}{c}0.415^{* * *} \\
(0.0271)\end{array}$ & $\begin{array}{c}-0.0710^{* * *} \\
(0.00582)\end{array}$ & $\begin{array}{c}0.0256^{* * *} \\
(0.00665)\end{array}$ & $\begin{array}{c}-0.102^{* * *} \\
(0.0112)\end{array}$ \\
\hline Germany & $\begin{array}{c}-1.401 * * * \\
(0.0451)\end{array}$ & $\begin{array}{c}-0.336 * * * \\
(0.0134)\end{array}$ & $\begin{array}{c}-0.693 * * * \\
(0.00463)\end{array}$ & $\begin{array}{c}-0.860 * * * \\
(0.00570)\end{array}$ & $\begin{array}{c}-0.257 * * * \\
(0.00778)\end{array}$ & $\begin{array}{c}-1.182^{* * *} \\
(0.00553)\end{array}$ & $\begin{array}{c}-1.200^{* * *} \\
(0.00889)\end{array}$ & $\begin{array}{c}-0.105^{* * *} \\
(0.00264)\end{array}$ & $\begin{array}{l}0.143 * * * \\
(0.00337)\end{array}$ & $\begin{array}{l}0.286^{* * *} \\
(0.00526)\end{array}$ \\
\hline France & $\begin{array}{l}1.347 * * * \\
(0.0319)\end{array}$ & $\begin{array}{c}-0.869 * * * \\
(0.0130)\end{array}$ & $\begin{array}{c}-1.347 * * * \\
(0.0184)\end{array}$ & $\begin{array}{c}-0.610 * * * \\
(0.0230)\end{array}$ & $\begin{array}{c}-0.954 * * * \\
(0.0127)\end{array}$ & $\begin{array}{c}-0.649 * * * \\
(0.0108)\end{array}$ & $\begin{array}{c}0.0410^{* *} \\
(0.0165)\end{array}$ & $\begin{array}{c}-0.0247 * * \\
(0.00714)\end{array}$ & $\begin{array}{l}0.543 * * * \\
(0.00223)\end{array}$ & $\begin{array}{l}0.702 * * * \\
(0.00393)\end{array}$ \\
\hline UK & $\begin{array}{c}2.084 * * * \\
(0.0172)\end{array}$ & $\begin{array}{c}-0.315^{* * *} \\
(0.00442)\end{array}$ & $\begin{array}{c}-0.489 * * * \\
(0.0243)\end{array}$ & $\begin{array}{c}-0.502^{* * *} \\
(0.0125)\end{array}$ & $\begin{array}{c}-0.728^{* * *} \\
(0.00614)\end{array}$ & $\begin{array}{c}-0.0184^{* * *} \\
(0.00290)\end{array}$ & $\begin{array}{c}-0.464 * * * \\
(0.00696)\end{array}$ & $\begin{array}{c}-0.157 * * * \\
(0.00165)\end{array}$ & $\begin{array}{c}-0.121 * * * \\
(0.00165)\end{array}$ & $\begin{array}{c}-0.0800^{* * *} \\
(0.00278)\end{array}$ \\
\hline Sweden & $\begin{array}{c}-0.635^{* * *} \\
(0.0368)\end{array}$ & $\begin{array}{l}0.528^{* * *} \\
(0.00652)\end{array}$ & $\begin{array}{c}0.658^{* * *} \\
(0.0185)\end{array}$ & $\begin{array}{c}0.655^{* * *} \\
(0.0138)\end{array}$ & $\begin{array}{c}0.709 * * * \\
(0.00936)\end{array}$ & $\begin{array}{c}-0.115^{* * *} \\
(0.00802)\end{array}$ & $\begin{array}{c}-0.310^{* * *} \\
(0.0147)\end{array}$ & $\begin{array}{c}0.201 * * * \\
(0.00407)\end{array}$ & $\begin{array}{c}-0.307^{* * *} \\
(0.00196)\end{array}$ & $\begin{array}{c}-0.476 * * * \\
(0.00198)\end{array}$ \\
\hline \multicolumn{11}{|c|}{1 st generation immigrants } \\
\hline Belgium & $\begin{array}{c}0.612^{* * *} \\
(0.162)\end{array}$ & $\begin{array}{c}-0.0804^{* * *} \\
(0.0119)\end{array}$ & $\begin{array}{c}-0.104 * * * \\
(0.0229)\end{array}$ & $\begin{array}{c}0.0950^{* * *} \\
(0.0201)\end{array}$ & $\begin{array}{c}-0.00974 \\
(0.0172)\end{array}$ & $\begin{array}{c}-0.423 * * * \\
(0.0151)\end{array}$ & $\begin{array}{c}-0.233 * * * \\
(0.0315)\end{array}$ & $\begin{array}{c}-0.125^{* * *} \\
(0.00581)\end{array}$ & $\begin{array}{c}0.271 * * * \\
(0.0173)\end{array}$ & $\begin{array}{c}0.107 * * * \\
(0.0240)\end{array}$ \\
\hline Switzerland & $\begin{array}{c}0.612^{* * *} \\
(0.138)\end{array}$ & $\begin{array}{c}-0.172^{* * *} \\
(0.0167)\end{array}$ & $\begin{array}{c}0.344 * * * \\
(0.0381)\end{array}$ & $\begin{array}{c}0.324 * * * \\
(0.0376)\end{array}$ & $\begin{array}{c}-0.103 * * \\
(0.0387)\end{array}$ & $\begin{array}{c}0.0923 * * \\
(0.0333)\end{array}$ & $\begin{array}{c}0.335^{* * *} \\
(0.0430)\end{array}$ & $\begin{array}{c}-0.0585^{* * *} \\
(0.0118)\end{array}$ & $\begin{array}{c}0.0629 * * \\
(0.0209)\end{array}$ & $\begin{array}{c}0.0923^{* *} \\
(0.0319)\end{array}$ \\
\hline Germany & $\begin{array}{c}-1.408^{* * *} \\
(0.247)\end{array}$ & $\begin{array}{c}0.249 * * * \\
(0.0338)\end{array}$ & $\begin{array}{c}0.213^{* * *} \\
(0.0293)\end{array}$ & $\begin{array}{c}0.191 * * * \\
(0.0354)\end{array}$ & $\begin{array}{c}0.191^{* * *} \\
(0.0458)\end{array}$ & $\begin{array}{c}0.248^{* * *} \\
(0.0191)\end{array}$ & $\begin{array}{c}0.601 * * * \\
(0.0434)\end{array}$ & $\begin{array}{c}0.0349 * * \\
(0.0134)\end{array}$ & $\begin{array}{c}-0.229 * * * \\
(0.0214)\end{array}$ & $\begin{array}{c}-0.193 * * * \\
(0.0306)\end{array}$ \\
\hline France & $\begin{array}{l}-0.354 \\
(0.220)\end{array}$ & $\begin{array}{c}0.0735^{* *} \\
(0.0212)\end{array}$ & $\begin{array}{c}0.0898^{*} \\
(0.0376)\end{array}$ & $\begin{array}{c}-0.146 * * \\
(0.0568)\end{array}$ & $\begin{array}{c}0.125^{* * *} \\
(0.0209)\end{array}$ & $\begin{array}{c}0.190 * * * \\
(0.0233)\end{array}$ & $\begin{array}{c}0.207 * * * \\
(0.0269)\end{array}$ & $\begin{array}{c}0.144 * * * \\
(0.0105)\end{array}$ & $\begin{array}{c}-0.0961 * * \\
(0.0373)\end{array}$ & $\begin{array}{c}-0.00196 \\
(0.0431)\end{array}$ \\
\hline UK & $\begin{array}{c}-1.485^{* * *} \\
(0.179)\end{array}$ & $\begin{array}{c}0.149 * * * \\
(0.0273)\end{array}$ & $\begin{array}{c}0.317^{* * *} \\
(0.0240)\end{array}$ & $\begin{array}{c}0.344^{* * *} \\
(0.0205)\end{array}$ & $\begin{array}{c}0.379 * * * \\
(0.0286)\end{array}$ & $\begin{array}{c}-0.271 * * * \\
(0.0216)\end{array}$ & $\begin{array}{c}-0.293^{* * *} \\
(0.0412)\end{array}$ & $\begin{array}{c}0.163^{* * *} \\
(0.00606)\end{array}$ & $\begin{array}{c}-0.128^{* * *} \\
(0.0163)\end{array}$ & $\begin{array}{c}-0.190 * * * \\
(0.0284)\end{array}$ \\
\hline
\end{tabular}




\begin{tabular}{|c|c|c|c|c|c|c|c|c|c|c|}
\hline Netherlands & $\begin{array}{c}1.054 * * * \\
(0.119)\end{array}$ & $\begin{array}{c}-0.107 * * * \\
(0.0201)\end{array}$ & $\begin{array}{c}-0.662 * * * \\
(0.0267)\end{array}$ & $\begin{array}{c}-0.420^{* * *} \\
(0.0292)\end{array}$ & $\begin{array}{c}-0.459^{* * *} \\
(0.0267)\end{array}$ & $\begin{array}{c}-0.139 * * * \\
(0.0178)\end{array}$ & $\begin{array}{c}-0.283^{* * *} \\
(0.0230)\end{array}$ & $\begin{array}{c}-0.147 \text { *** } \\
(0.0110)\end{array}$ & $\begin{array}{c}0.109^{* * *} \\
(0.0150)\end{array}$ & $\begin{array}{c}0.191 \text { *** } \\
(0.0244)\end{array}$ \\
\hline Sweden & $\begin{array}{c}0.968^{* * *} \\
(0.0610)\end{array}$ & $\begin{array}{c}-0.112 * * * \\
(0.0106)\end{array}$ & $\begin{array}{c}-0.198^{* * *} \\
(0.0187)\end{array}$ & $\begin{array}{c}-0.388 * * * \\
(0.0213)\end{array}$ & $\begin{array}{c}-0.124^{* * *} \\
(0.0170)\end{array}$ & $\begin{array}{c}0.302^{* * *} \\
(0.0135)\end{array}$ & $\begin{array}{c}-0.334 * * * \\
(0.0152)\end{array}$ & $\begin{array}{c}-0.0112 \\
(0.00634)\end{array}$ & $\begin{array}{c}0.0107 \\
(0.0152)\end{array}$ & $\begin{array}{c}-0.00453 \\
(0.0224)\end{array}$ \\
\hline \multicolumn{11}{|c|}{$2^{\text {nd }}$ generation immigrants } \\
\hline Belgium & $\begin{array}{c}-1.179 * * * \\
(0.181)\end{array}$ & $\begin{array}{c}-0.145^{* * *} \\
(0.0253)\end{array}$ & $\begin{array}{l}-0.0250 \\
(0.0248)\end{array}$ & $\begin{array}{c}0.160^{* * *} \\
(0.0234)\end{array}$ & $\begin{array}{c}-0.0505^{* * *} \\
(0.00813)\end{array}$ & $\begin{array}{c}-0.267 * * * \\
(0.0152)\end{array}$ & $\begin{array}{c}-0.151 * * * \\
(0.0220)\end{array}$ & $\begin{array}{c}-0.181 * * * \\
(0.00595)\end{array}$ & $\begin{array}{c}0.269 * * * \\
(0.0136)\end{array}$ & $\begin{array}{c}0.134^{* * *} \\
(0.0212)\end{array}$ \\
\hline Switzerland & $\begin{array}{c}0.836^{* *} \\
(0.254)\end{array}$ & $\begin{array}{c}-0.115^{\text {*** }} \\
(0.0229)\end{array}$ & $\begin{array}{c}0.0233 \\
(0.0416)\end{array}$ & $\begin{array}{c}0.170^{* * *} \\
(0.0317)\end{array}$ & $\begin{array}{l}0.133 * * \\
(0.0432)\end{array}$ & $\begin{array}{c}0.0333 \\
(0.0443)\end{array}$ & $\begin{array}{c}0.446^{* * *} \\
(0.0510)\end{array}$ & $\begin{array}{c}-0.0345^{*} \\
(0.0170)\end{array}$ & $\begin{array}{c}0.260 * * * \\
(0.0233)\end{array}$ & $\begin{array}{c}0.252^{* * *} \\
(0.0436)\end{array}$ \\
\hline Germany & $\begin{array}{c}-1.041 * * * \\
(0.148)\end{array}$ & $\begin{array}{c}-0.153 * * * \\
(0.0206)\end{array}$ & $\begin{array}{c}-0.0506^{* *} \\
(0.0189)\end{array}$ & $\begin{array}{c}0.212^{* * *} \\
(0.0341)\end{array}$ & $\begin{array}{c}0.0844 * * \\
(0.0282)\end{array}$ & $\begin{array}{l}0.516^{* * *} \\
(0.00846)\end{array}$ & $\begin{array}{c}0.515^{* * *} \\
(0.0140)\end{array}$ & $\begin{array}{c}-0.0765^{* * *} \\
(0.00747)\end{array}$ & $\begin{array}{c}-0.204 * * * \\
(0.0118)\end{array}$ & $\begin{array}{l}-0.0404 \\
(0.0244)\end{array}$ \\
\hline France & $\begin{array}{l}0.0831 \\
(0.213)\end{array}$ & $\begin{array}{c}0.255^{* * *} \\
(0.0220)\end{array}$ & $\begin{array}{c}0.258 * * * \\
(0.0370)\end{array}$ & $\begin{array}{c}-0.313^{* * *} \\
(0.0507)\end{array}$ & $\begin{array}{c}0.0153 \\
(0.0175)\end{array}$ & $\begin{array}{c}0.185^{* * *} \\
(0.0232)\end{array}$ & $\begin{array}{c}0.0346 \\
(0.0463)\end{array}$ & $\begin{array}{l}0.127^{* * *} \\
(0.0105)\end{array}$ & $\begin{array}{l}-0.0389 \\
(0.0308)\end{array}$ & $\begin{array}{c}-0.283 \text { *** } \\
(0.0390)\end{array}$ \\
\hline UK & $\begin{array}{c}0.139 \\
(0.363)\end{array}$ & $\begin{array}{c}-0.329 * * * \\
(0.0303)\end{array}$ & $\begin{array}{c}0.228 * * * \\
(0.0385)\end{array}$ & $\begin{array}{c}0.248^{* * *} \\
(0.0350)\end{array}$ & $\begin{array}{c}0.0243 \\
(0.0349)\end{array}$ & $\begin{array}{c}-0.212^{* * *} \\
(0.0300)\end{array}$ & $\begin{array}{c}-0.391 * * * \\
(0.0596)\end{array}$ & $\begin{array}{c}0.108^{* * *} \\
(0.0112)\end{array}$ & $\begin{array}{c}0.0770^{* *} \\
(0.0214)\end{array}$ & $\begin{array}{c}0.254 * * * \\
(0.0426)\end{array}$ \\
\hline Netherlands & $\begin{array}{c}1.463 * * * \\
(0.346)\end{array}$ & $\begin{array}{c}0.305^{* * *} \\
(0.0448)\end{array}$ & $\begin{array}{c}-0.642 * * * \\
(0.0594)\end{array}$ & $\begin{array}{c}-0.359 * * * \\
(0.0439)\end{array}$ & $\begin{array}{c}-0.239 * * * \\
(0.0547)\end{array}$ & $\begin{array}{c}-0.414 * * * \\
(0.0524)\end{array}$ & $\begin{array}{l}-0.0969 \\
(0.0848)\end{array}$ & $\begin{array}{l}-0.0277 \\
(0.0184)\end{array}$ & $\begin{array}{c}0.0133 \\
(0.0250)\end{array}$ & $\begin{array}{l}-0.0157 \\
(0.0533)\end{array}$ \\
\hline Sweden & $\begin{array}{l}-0.300 \\
(0.206)\end{array}$ & $\begin{array}{c}0.182 * * * \\
(0.0214)\end{array}$ & $\begin{array}{c}0.209 * * * \\
(0.0381)\end{array}$ & $\begin{array}{c}-0.118^{* *} \\
(0.0385)\end{array}$ & $\begin{array}{c}0.0322 \\
(0.0388)\end{array}$ & $\begin{array}{c}0.159^{* * *} \\
(0.0319)\end{array}$ & $\begin{array}{c}-0.357 * * * \\
(0.0470)\end{array}$ & $\begin{array}{c}0.0850^{* * *} \\
(0.0122)\end{array}$ & $\begin{array}{c}-0.376^{* * *} \\
(0.0214)\end{array}$ & $\begin{array}{c}-0.301 * * * \\
(0.0284)\end{array}$ \\
\hline 1st generation & $\begin{array}{c}0.878^{* * *} \\
(0.184)\end{array}$ & $\begin{array}{c}-0.290 * * * \\
(0.0136)\end{array}$ & $\begin{array}{c}0.253 * * * \\
(0.0536)\end{array}$ & $\begin{array}{c}0.505^{* * * *} \\
(0.0451)\end{array}$ & $\begin{array}{c}0.515^{* * *} * \\
(0.0363)\end{array}$ & $\begin{array}{c}-0.190 * * * \\
(0.0394)\end{array}$ & $\begin{array}{c}0.145^{* * *} \\
(0.0375)\end{array}$ & $\begin{array}{c}-0.225^{* * *} \\
(0.0164)\end{array}$ & $\begin{array}{c}0.241 * * * \\
(0.0298)\end{array}$ & $\begin{array}{c}0.0590 \\
(0.0528)\end{array}$ \\
\hline $2^{\text {nd }}$ generation & $\begin{array}{c}-0.638^{* * *} \\
(0.123)\end{array}$ & $\begin{array}{c}-0.307 * * * \\
(0.0297)\end{array}$ & $\begin{array}{c}-0.163 * * \\
(0.0551)\end{array}$ & $\begin{array}{c}0.0176 \\
(0.0565)\end{array}$ & $\begin{array}{l}-0.0370 \\
(0.0473)\end{array}$ & $\begin{array}{c}-0.519 * * * \\
(0.0450)\end{array}$ & $\begin{array}{c}-0.177^{* *} \\
(0.0618)\end{array}$ & $\begin{array}{c}-0.265^{* * *} \\
(0.0152)\end{array}$ & $\begin{array}{c}0.265^{* * *} \\
(0.0207)\end{array}$ & $\begin{array}{c}0.221 * * * \\
(0.0457)\end{array}$ \\
\hline Constant & $\begin{array}{c}15.89 * * * \\
(0.969)\end{array}$ & $\begin{array}{c}5.651^{* * *} \\
(0.289)\end{array}$ & $\begin{array}{c}2.710^{* * *} \\
(0.665)\end{array}$ & $\begin{array}{c}3.549 * * * \\
(0.313)\end{array}$ & $\begin{array}{c}3.581 * * * \\
(0.237)\end{array}$ & $\begin{array}{c}7.586^{* * *} \\
(0.331)\end{array}$ & $\begin{array}{c}6.613^{* * *} \\
(0.448)\end{array}$ & $\begin{array}{l}0.371 * \\
(0.181)\end{array}$ & $\begin{array}{c}3.793^{* * *} \\
(0.201)\end{array}$ & $\begin{array}{c}4.327^{* * *} \\
(0.316)\end{array}$ \\
\hline Observations & 8.369 & 44,422 & 43.998 & 43.620 & 43.740 & 43.264 & 44.229 & 42.425 & 8.988 & 8.378 \\
\hline R-squared & 0.110 & 0.149 & 0.182 & 0.113 & 0.124 & 0.121 & 0.147 & 0.282 & 0.112 & 0.194 \\
\hline
\end{tabular}

Other controls: age, age square, marital status, male, log income, region of origin, migration status, employment status, year fixed-effects. Variables recoded in ascending order when necessary.

The coefficients of country fixed-effects reflect deviations from the "grand mean" rather than deviations from the reference category.

Robust standard errors clustered by country. 
Table E1.B OLS Estimates of Satisfaction viz. Different Domains. Immigrants from EU only.

\begin{tabular}{|c|c|c|c|c|c|c|c|c|c|c|}
\hline & $(1)$ & & $(2)$ & (3) & (4) & (5) & $(6)$ & $(7)$ & $(8)$ & $(18)$ \\
\hline & $\begin{array}{c}\text { Depressiveness } \\
\text { Index } \\
(0-59)\end{array}$ & $\begin{array}{c}\text { Life } \\
\text { Satisfaction } \\
\text { Sflife } \\
(0-10\end{array}$ & $\begin{array}{c}\text { Satisfaction } \\
\text { with Economy } \\
\text { (stfeco) } \\
(0-10)\end{array}$ & $\begin{array}{c}\text { Satisfaction with } \\
\text { national } \\
\text { government } \\
\text { (stfgov) } \\
(0-10)\end{array}$ & $\begin{array}{c}\text { Satisfaction with } \\
\text { democracy } \\
\text { (stfdem) } \\
(0-10)\end{array}$ & $\begin{array}{c}\text { Satisfaction with } \\
\text { education system } \\
\text { (stfedu) } \\
(0-10)\end{array}$ & $\begin{array}{c}\text { Satisfaction } \\
\text { with Health } \\
\text { system } \\
\text { (stfhlth) } \\
(0-10)\end{array}$ & $\begin{array}{c}\text { Living } \\
\text { comfortably on } \\
\text { present income } \\
\text { (bincfel) } \\
\text { (1-4) }\end{array}$ & $\begin{array}{l}\text { Hard to be hopeful } \\
\text { about the future of the } \\
\text { world } \\
(\text { nhpftr) } \\
(1-5)\end{array}$ & $\begin{array}{c}\text { For most people in } \\
\text { country } \\
\text { life is getting worse } \\
\text { (lfwrrs) } \\
(1-5)\end{array}$ \\
\hline Belgium & $\begin{array}{c}0.353^{* * *} \\
(0.0203)\end{array}$ & $\begin{array}{c}0.235^{* * *} \\
(0.0183)\end{array}$ & $\begin{array}{l}0.359 * * * \\
(0.00863)\end{array}$ & $\begin{array}{c}0.0166 \\
(0.0112)\end{array}$ & $\begin{array}{c}-0.114^{* * *} \\
(0.0140)\end{array}$ & $\begin{array}{c}1.008^{* * *} \\
(0.0105)\end{array}$ & $\begin{array}{c}1.462^{* * *} \\
(0.0106)\end{array}$ & $\begin{array}{c}0.0359^{* * *} \\
(0.00349)\end{array}$ & $\begin{array}{c}0.0235^{* * *} \\
(0.00208)\end{array}$ & $\begin{array}{c}0.0396^{* * *} \\
(0.00482)\end{array}$ \\
\hline Germany & $\begin{array}{c}-1.419 * * * \\
(0.0440)\end{array}$ & $\begin{array}{c}-0.337^{* * *} \\
(0.0139)\end{array}$ & $\begin{array}{c}-0.689 * * * \\
(0.00550)\end{array}$ & $\begin{array}{c}-0.856^{* * *} \\
(0.00645)\end{array}$ & $\begin{array}{c}-0.252^{* * *} \\
(0.00861)\end{array}$ & $\begin{array}{c}-1.181 * * * \\
(0.00608)\end{array}$ & $\begin{array}{c}-1.196^{* * *} \\
(0.00897)\end{array}$ & $\begin{array}{l}-0.105^{* * *} \\
(0.00268)\end{array}$ & $\begin{array}{l}0.143^{* * *} \\
(0.00372)\end{array}$ & $\begin{array}{l}0.282^{* * *} \\
(0.00552)\end{array}$ \\
\hline France & $\begin{array}{c}1.343^{* * *} \\
(0.0327)\end{array}$ & $\begin{array}{c}-0.870 * * * \\
(0.0143)\end{array}$ & $\begin{array}{c}-1.343^{* * *} \\
(0.0206)\end{array}$ & $\begin{array}{c}-0.602 * * * \\
(0.0252)\end{array}$ & $\begin{array}{c}-0.950 * * * \\
(0.0149)\end{array}$ & $\begin{array}{c}-0.642^{* * *} \\
(0.0113)\end{array}$ & $\begin{array}{c}0.0471 * * \\
(0.0156)\end{array}$ & $\begin{array}{c}-0.0262 * * \\
(0.00826)\end{array}$ & $\begin{array}{l}0.542^{* * *} \\
(0.00209)\end{array}$ & $\begin{array}{c}0.698 * * * \\
(0.00376)\end{array}$ \\
\hline Great-Britain & $\begin{array}{c}2.102 * * * \\
(0.0161)\end{array}$ & $\begin{array}{c}-0.312^{* * *} \\
(0.00449)\end{array}$ & $\begin{array}{c}-0.493^{* * *} \\
(0.0238)\end{array}$ & $\begin{array}{c}-0.504^{* * *} \\
(0.0122)\end{array}$ & $\begin{array}{c}-0.731 \text { *** } \\
(0.00626)\end{array}$ & $\begin{array}{c}-0.0178^{* * *} \\
(0.00308)\end{array}$ & $\begin{array}{c}-0.461 * * * \\
(0.00757)\end{array}$ & $\begin{array}{c}-0.158^{* * *} \\
(0.00152)\end{array}$ & $\begin{array}{c}-0.116^{* * *} \\
(0.00148)\end{array}$ & $\begin{array}{c}-0.0722^{* * *} \\
(0.00270)\end{array}$ \\
\hline Netherlands & $\begin{array}{c}-0.563^{* * *} \\
(0.0306)\end{array}$ & $\begin{array}{l}0.295^{* * *} \\
(0.00952)\end{array}$ & $\begin{array}{c}0.806^{* * *} \\
(0.0206)\end{array}$ & $\begin{array}{l}0.413^{* * *} \\
(0.00970)\end{array}$ & $\begin{array}{c}0.455^{* * *} \\
(0.00517)\end{array}$ & $\begin{array}{l}0.265^{* * *} \\
(0.00612)\end{array}$ & $\begin{array}{c}0.0660^{* * *} \\
(0.00568)\end{array}$ & $\begin{array}{l}0.123^{* * *} \\
(0.00345)\end{array}$ & $\begin{array}{c}-0.314^{* * *} \\
(0.00185)\end{array}$ & $\begin{array}{c}-0.376^{* * *} \\
(0.00263)\end{array}$ \\
\hline Sweden & $\begin{array}{c}-0.612^{* * *} \\
(0.0299)\end{array}$ & $\begin{array}{l}0.527 * * * \\
(0.00643)\end{array}$ & $\begin{array}{c}0.658^{* * *} \\
(0.0189)\end{array}$ & $\begin{array}{c}0.652^{* * *} \\
(0.0152)\end{array}$ & $\begin{array}{c}0.708^{* * *} \\
(0.0111)\end{array}$ & $\begin{array}{c}-0.121 * * * \\
(0.00941)\end{array}$ & $\begin{array}{c}-0.311 * * * \\
(0.0155)\end{array}$ & $\begin{array}{l}0.202^{* * *} \\
(0.00401)\end{array}$ & $\begin{array}{c}-0.305^{* * *} \\
(0.00234)\end{array}$ & $\begin{array}{c}-0.476^{* * *} \\
(0.00296)\end{array}$ \\
\hline \multicolumn{11}{|c|}{ 1st generation immigrants } \\
\hline Belgium & $\begin{array}{c}0.753^{* * *} \\
(0.0540)\end{array}$ & $\begin{array}{c}-0.0850^{* * *} \\
(0.00769)\end{array}$ & $\begin{array}{c}-0.354 * * * \\
(0.0175)\end{array}$ & $\begin{array}{c}-0.130^{* * *} \\
(0.0132)\end{array}$ & $\begin{array}{c}-0.168^{* * *} \\
(0.00806)\end{array}$ & $\begin{array}{c}-0.456^{* * *} \\
(0.00794)\end{array}$ & $\begin{array}{c}-0.232^{* * *} \\
(0.0110)\end{array}$ & $\begin{array}{c}-0.165^{* * *} \\
(0.00175)\end{array}$ & $\begin{array}{l}0.120^{* * *} \\
(0.00274)\end{array}$ & $\begin{array}{c}0.125^{* * *} \\
(0.0102)\end{array}$ \\
\hline Switzerland & $\begin{array}{c}0.942^{* * *} \\
(0.0248)\end{array}$ & $\begin{array}{c}-0.152 * * * \\
(0.00216)\end{array}$ & $\begin{array}{l}0.312^{* * *} \\
(0.00977)\end{array}$ & $\begin{array}{c}0.380^{* * *} \\
(0.0109)\end{array}$ & $\begin{array}{c}-0.120 * * * \\
(0.00785)\end{array}$ & $\begin{array}{c}0.0590^{* * *} \\
(0.00502)\end{array}$ & $\begin{array}{l}0.329 * * * \\
(0.00607)\end{array}$ & $\begin{array}{c}-0.0577 * * * \\
(0.00187)\end{array}$ & $\begin{array}{c}0.0517^{* * *} \\
(0.00310)\end{array}$ & $\begin{array}{l}0.122^{* * *} \\
(0.00392)\end{array}$ \\
\hline Germany & $\begin{array}{c}-2.572^{* * *} \\
(0.0348)\end{array}$ & $\begin{array}{l}0.317 * * * \\
(0.00952)\end{array}$ & $\begin{array}{l}0.248^{* * *} \\
(0.0124)\end{array}$ & $\begin{array}{c}0.258^{* * *} \\
(0.0113)\end{array}$ & $\begin{array}{c}0.293^{* * *} \\
(0.0126)\end{array}$ & $\begin{array}{c}-0.0729 * * * \\
(0.00976)\end{array}$ & $\begin{array}{l}0.389 * * * \\
(0.00583)\end{array}$ & $\begin{array}{c}0.0798^{* * *} \\
(0.00464)\end{array}$ & $\begin{array}{l}-0.206^{* * *} \\
(0.00736)\end{array}$ & $\begin{array}{l}-0.183^{* * *} \\
(0.00805)\end{array}$ \\
\hline France & $\begin{array}{l}-0.0549 \\
(0.0722)\end{array}$ & $\begin{array}{c}0.0379 * * \\
(0.0150)\end{array}$ & $\begin{array}{l}0.0918^{*} \\
(0.0463)\end{array}$ & $\begin{array}{c}0.0251 \\
(0.0245)\end{array}$ & $\begin{array}{c}0.0111 \\
(0.0125)\end{array}$ & $\begin{array}{l}0.553^{* * *} \\
(0.00883)\end{array}$ & $\begin{array}{l}0.269 * * * \\
(0.00841)\end{array}$ & $\begin{array}{l}0.110^{* * *} \\
(0.00518)\end{array}$ & $\begin{array}{l}-0.166 \text { *** } \\
(0.00664)\end{array}$ & $\begin{array}{c}0.00356 \\
(0.00879)\end{array}$ \\
\hline Great-Britain & $\begin{array}{c}-1.411 * * * \\
(0.0479)\end{array}$ & $\begin{array}{c}-0.109 * * * \\
(0.0220)\end{array}$ & $\begin{array}{l}0.104^{* *} \\
(0.0317)\end{array}$ & $\begin{array}{c}0.0737^{* * *} \\
(0.0163)\end{array}$ & $\begin{array}{c}0.0645^{* * *} \\
(0.0124)\end{array}$ & $\begin{array}{c}-0.334 * * * \\
(0.0119)\end{array}$ & $\begin{array}{l}-0.516^{* * *} \\
(0.00977)\end{array}$ & $\begin{array}{c}0.0668^{* * *} \\
(0.00617)\end{array}$ & $\begin{array}{l}0.0204 * * \\
(0.00603)\end{array}$ & $\begin{array}{c}-0.0605^{* * *} \\
(0.00983)\end{array}$ \\
\hline Netherlands & $\begin{array}{c}2.238^{* * *} \\
(0.108)\end{array}$ & $\begin{array}{c}0.0887^{* * *} \\
(0.0158)\end{array}$ & $\begin{array}{c}-0.138^{* * *} \\
(0.0132)\end{array}$ & $\begin{array}{c}-0.175^{* * *} \\
(0.0153)\end{array}$ & $\begin{array}{l}-0.00127 \\
(0.00728)\end{array}$ & $\begin{array}{c}0.207 * * * \\
(0.0123)\end{array}$ & $\begin{array}{c}0.0803^{* * *} \\
(0.0140)\end{array}$ & $\begin{array}{c}-0.0210^{* * *} \\
(0.00192)\end{array}$ & $\begin{array}{l}0.152^{* * *} \\
(0.00450)\end{array}$ & $\begin{array}{l}0.208^{* * *} \\
(0.00931)\end{array}$ \\
\hline Sweden & $\begin{array}{l}0.106^{* *} \\
(0.0382)\end{array}$ & $\begin{array}{c}-0.0984 * * * \\
(0.0134)\end{array}$ & $\begin{array}{c}-0.264^{* * *} \\
(0.0122)\end{array}$ & $\begin{array}{c}-0.432^{* * *} \\
(0.0108)\end{array}$ & $\begin{array}{c}-0.0793^{* * *} \\
(0.0108)\end{array}$ & $\begin{array}{c}0.0447^{* *} \\
(0.0130)\end{array}$ & $\begin{array}{c}-0.320^{* * *} \\
(0.0106)\end{array}$ & $\begin{array}{l}-0.0127^{*} \\
(0.00535)\end{array}$ & $\begin{array}{c}0.0286^{* * *} \\
(0.00391)\end{array}$ & $\begin{array}{c}-0.216^{* * *} \\
(0.00675)\end{array}$ \\
\hline
\end{tabular}




\begin{tabular}{|c|c|c|c|c|c|c|c|c|c|c|}
\hline \multicolumn{11}{|c|}{$2^{\text {nd }}$ generation immigrants } \\
\hline Belgium & $\begin{array}{c}-1.495^{* * *} \\
(0.0399)\end{array}$ & $\begin{array}{c}-0.145^{* * *} \\
(0.0308)\end{array}$ & $\begin{array}{c}-0.290 * * * \\
(0.0353)\end{array}$ & $\begin{array}{l}-0.0313 \\
(0.0245)\end{array}$ & $\begin{array}{c}-0.248^{* * *} \\
(0.0162)\end{array}$ & $\begin{array}{c}-0.235^{* * *} \\
(0.0112)\end{array}$ & $\begin{array}{c}-0.0947 * * * \\
(0.0115)\end{array}$ & $\begin{array}{l}-0.333^{* * *} \\
(0.00906)\end{array}$ & $\begin{array}{l}0.356^{* * *} \\
(0.00424)\end{array}$ & $\begin{array}{l}0.351 * * * \\
(0.00687)\end{array}$ \\
\hline Switzerland & $\begin{array}{l}-0.0752 \\
(0.0555)\end{array}$ & $\begin{array}{c}-0.0625^{* *} \\
(0.0191)\end{array}$ & $\begin{array}{c}-0.199 * * * \\
(0.0142)\end{array}$ & $\begin{array}{c}0.0491 * * * \\
(0.00918)\end{array}$ & $\begin{array}{c}-0.0357 * * \\
(0.0146)\end{array}$ & $\begin{array}{c}-0.0656^{* * *} \\
(0.0115)\end{array}$ & $\begin{array}{c}0.256^{* * *} \\
(0.0169)\end{array}$ & $\begin{array}{l}0.0275^{* *} \\
(0.00790)\end{array}$ & $\begin{array}{l}0.314^{* * *} \\
(0.00638)\end{array}$ & $\begin{array}{l}0.361 * * * \\
(0.00779)\end{array}$ \\
\hline Germany & $\begin{array}{c}0.222^{* * *} \\
(0.0422)\end{array}$ & $\begin{array}{c}-0.196 * * * \\
(0.00688)\end{array}$ & $\begin{array}{c}-0.142^{* * *} \\
(0.0216)\end{array}$ & $\begin{array}{c}0.114^{* * *} \\
(0.0188)\end{array}$ & $\begin{array}{c}-0.146 * * * \\
(0.00653)\end{array}$ & $\begin{array}{l}0.518^{* * *} \\
(0.00996)\end{array}$ & $\begin{array}{l}0.0316^{*} \\
(0.0139)\end{array}$ & $\begin{array}{c}-0.0323^{* * *} \\
(0.00318)\end{array}$ & $\begin{array}{c}-0.0142 * * \\
(0.00442)\end{array}$ & $\begin{array}{c}-0.0619 * * * \\
(0.00448)\end{array}$ \\
\hline France & $\begin{array}{c}0.439 * * * \\
(0.0873)\end{array}$ & $\begin{array}{c}0.0994^{* * *} \\
(0.0147)\end{array}$ & $\begin{array}{c}-0.0587 * * * \\
(0.0111)\end{array}$ & $\begin{array}{c}-0.149 * * * \\
(0.0182)\end{array}$ & $\begin{array}{c}-0.368^{* * *} \\
(0.0160)\end{array}$ & $\begin{array}{c}-0.0966^{* * *} \\
(0.00670)\end{array}$ & $\begin{array}{c}-0.277 * * * \\
(0.0191)\end{array}$ & $\begin{array}{c}0.0213^{*} \\
(0.00890)\end{array}$ & $\begin{array}{l}0.369 * * * \\
(0.00672)\end{array}$ & $\begin{array}{l}0.146^{* * *} \\
(0.00880)\end{array}$ \\
\hline Great-Britain & $\begin{array}{c}-1.050^{* * *} \\
(0.0638)\end{array}$ & $\begin{array}{c}-0.184 * * * \\
(0.00833)\end{array}$ & $\begin{array}{c}0.246^{* * *} \\
(0.0261)\end{array}$ & $\begin{array}{c}0.379 * * * \\
(0.0229)\end{array}$ & $\begin{array}{c}0.143 * * * \\
(0.00929)\end{array}$ & $\begin{array}{c}-0.113 * * * \\
(0.0114)\end{array}$ & $\begin{array}{c}-0.146 * * * \\
(0.0134)\end{array}$ & $\begin{array}{c}0.0268^{* * *} \\
(0.00397)\end{array}$ & $\begin{array}{c}-0.663 * * * \\
(0.0154)\end{array}$ & $\begin{array}{c}-0.725^{* * *} \\
(0.0109)\end{array}$ \\
\hline Netherlands & $\begin{array}{c}3.804 * * * \\
(0.145)\end{array}$ & $\begin{array}{c}0.289 * * * \\
(0.0323)\end{array}$ & $\begin{array}{c}0.417 * * * \\
(0.0323)\end{array}$ & $\begin{array}{c}-0.237 * * * \\
(0.0299)\end{array}$ & $\begin{array}{c}0.783^{* * *} \\
(0.0234)\end{array}$ & $\begin{array}{l}-0.0111 \\
(0.0161)\end{array}$ & $\begin{array}{c}0.790^{* * *} \\
(0.0364)\end{array}$ & $\begin{array}{l}0.204^{* * *} \\
(0.00600)\end{array}$ & $\begin{array}{c}-0.128^{* * *} \\
(0.0214)\end{array}$ & $\begin{array}{c}0.0933^{* * *} \\
(0.0116)\end{array}$ \\
\hline Sweden & $\begin{array}{c}-1.844^{* * *} \\
(0.0960)\end{array}$ & $\begin{array}{l}0.198^{* * *} \\
(0.00528)\end{array}$ & $\begin{array}{c}0.0270 \\
(0.0172)\end{array}$ & $\begin{array}{c}-0.124 * * * \\
(0.0170)\end{array}$ & $\begin{array}{c}-0.129 * * * \\
(0.00919)\end{array}$ & $\begin{array}{c}0.00373 \\
(0.00802)\end{array}$ & $\begin{array}{c}-0.560 * * * \\
(0.00430)\end{array}$ & $\begin{array}{c}0.0852^{* * *} \\
(0.00409)\end{array}$ & $\begin{array}{c}-0.234 * * * \\
(0.00564)\end{array}$ & $\begin{array}{c}-0.164 * * * \\
(0.00916)\end{array}$ \\
\hline 1st generation & $\begin{array}{c}0.949 * * * \\
(0.0665)\end{array}$ & $\begin{array}{c}-0.264 * * * \\
(0.0158)\end{array}$ & $\begin{array}{l}-0.0229 \\
(0.0231)\end{array}$ & $\begin{array}{c}0.155^{* * * *} \\
(0.0172)\end{array}$ & $\begin{array}{c}0.301 * * * \\
(0.0123)\end{array}$ & $\begin{array}{c}-0.232 * * * \\
(0.00859)\end{array}$ & $\begin{array}{c}0.120^{* * *} \\
(0.0225)\end{array}$ & $\begin{array}{c}-0.221 * * * \\
(0.00261)\end{array}$ & $\begin{array}{c}0.0997 * * * \\
(0.00398)\end{array}$ & $\begin{array}{c}0.0971 * * * \\
(0.0120)\end{array}$ \\
\hline 2nd-generation & $\begin{array}{c}0.0169 \\
(0.0480)\end{array}$ & $\begin{array}{c}-0.314 * * * \\
(0.0327)\end{array}$ & $\begin{array}{c}-0.203 * * * \\
(0.0383)\end{array}$ & $\begin{array}{l}-0.0250 \\
(0.0230)\end{array}$ & $\begin{array}{c}-0.0343 * \\
(0.0167)\end{array}$ & $\begin{array}{c}-0.394 * * * \\
(0.0121)\end{array}$ & $\begin{array}{c}0.0911^{* * *} \\
(0.0141)\end{array}$ & $\begin{array}{c}-0.463 * * * \\
(0.00608)\end{array}$ & $\begin{array}{l}0.284^{* * *} \\
(0.00349)\end{array}$ & $\begin{array}{l}0.298^{* * *} \\
(0.00703)\end{array}$ \\
\hline Constant & $\begin{array}{c}15.73^{* * *} \\
(1.026)\end{array}$ & $\begin{array}{c}5.539 * * * \\
(0.341)\end{array}$ & $\begin{array}{c}3.014^{* * *} \\
(0.666)\end{array}$ & $\begin{array}{c}3.666^{* * *} \\
(0.342)\end{array}$ & $\begin{array}{c}3.526^{* * *} \\
(0.243)\end{array}$ & $\begin{array}{c}7.183^{* * *} \\
(0.329)\end{array}$ & $\begin{array}{c}6.031 * * * \\
(0.418)\end{array}$ & $\begin{array}{c}0.662^{* * *} \\
(0.160)\end{array}$ & $\begin{array}{c}3.936^{* * *} \\
(0.164)\end{array}$ & $\begin{array}{c}4.299 * * * \\
(0.245)\end{array}$ \\
\hline Observations & 7.738 & 40,910 & 40.544 & 40.250 & 40.337 & 39.886 & 40.744 & 39.054 & 8.292 & 7.733 \\
\hline R-squared & 0.108 & 0.151 & 0.189 & 0.113 & 0.125 & 0.123 & 0.148 & 0.269 & 0.115 & 0.202 \\
\hline
\end{tabular}

Other controls: age, age square, marital status, male, log income, migration status, employment status, year fixed-effects.

Variables recoded in ascending order when necessary.

The coefficients of country fixed-effects reflect deviations from the "grand mean" rather than deviations from the reference category.

Robust standard errors clustered by country. 